PENGARUH STRATEGI PEMBELAJARAN BERBASIS PROYEK BERBANTUAN MEDIA $D V D$ 6M TERHADAP KEMAMPUAN BERPIKIR KRITIS, PENGETAHUAN, SIKAP, DAN

KETERAMPILAN DALAM PENGELOLAAN LINGKUNGAN PADA MATA PELAJARAN BIOLOGI SISWA DI SMAN SUMBAWA

TESIS

\author{
OLEH \\ SUPRATMAN \\ NIM 100341505611
}

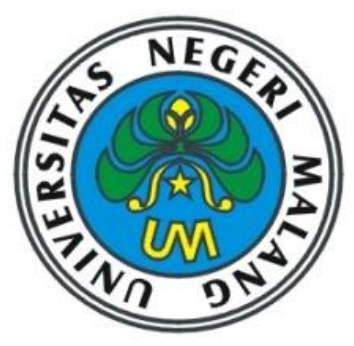

UNIVERSITAS NEGERI MALANG

PROGRAM PASCASARJANA

PROGRAM STUDI PENDIDIKAN BIOLOGI

JUNI 2012 


\title{
PENGARUH STRATEGI PEMBELAJARAN BERBASIS PROYEK BERBANTUAN MEDIA $D V D$ 6M TERHADAP KEMAMPUAN BERPIKIR KRITIS, PENGETAHUAN, SIKAP, DAN KETERAMPILAN DALAM PENGELOLAAN LINGKUNGAN PADA MATA PELAJARAN BIOLOGI SISWA SMAN SUMBAWA
}

\author{
TESIS \\ Diajukan kepada \\ Universitas Negeri Malang \\ untuk memenuhi salah satu persyaratan \\ dalam menyelesaikan program Magister \\ Pendidikan Biologi
}

Oleh

Supratman NIM 100341505611

\author{
UNIVERSITAS NEGERI MALANG \\ PROGRAM PASCASARJANA \\ PROGRAM STUDI PENDIDIKAN BIOLOGI \\ JUNI 2012
}




\section{IEMBAR PERSETUJUAN PEMBIMBING}

Tesis olch Supratman ins tclah dipcriksa dan disetuju untuk diuji.

Malang, 21 Mci 2012

Pembimbing I

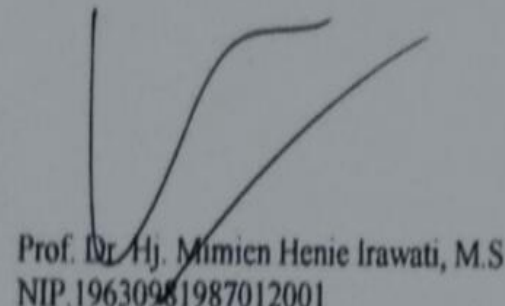

Malang, Juni 2012

Pembimbing II

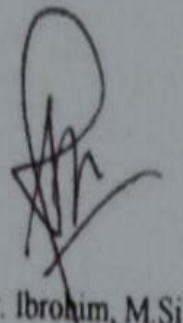

NIP. 1966) 1041991031001 
Tesis oleh Supratman ini telah dipertahankan di depan dewan penguji

Pada tanggal 18 Juni 2012

Dewan Penguji

with.lnin

Prof. Dr. agr. H. Mohammad Amin, S.Pd., M.Si,

Ketua

NIP. 196701191992031002

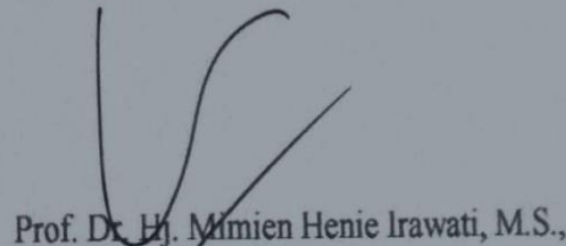

NIP.19630908 1987012001

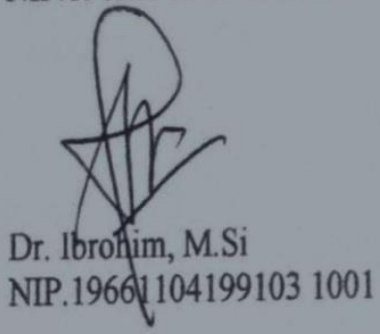

Anggota

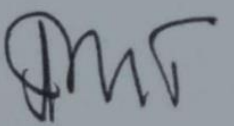

Anggota

NIP.19661104199103 1001

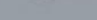

Prof. Dr. H. Punaji Setyosari, M.Ed,

NIP. 195906151986011001

Anggota

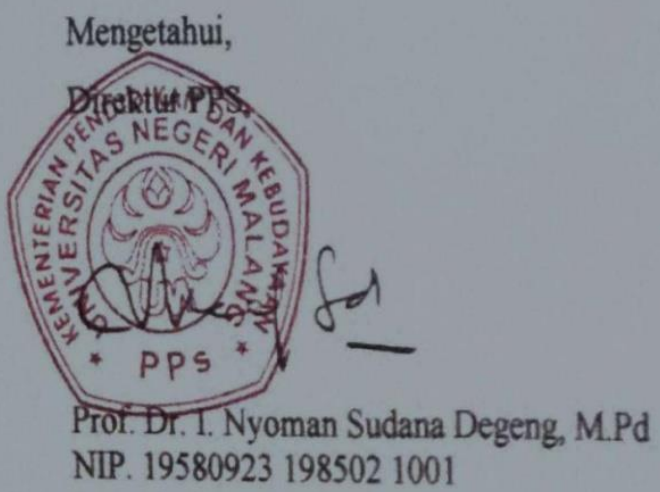




\section{PERNYATAAN KEASLIAN TULISAN}

Saya yang bertanda tangan di bawah ini:

$\begin{array}{ll}\text { Nama } & \text { : Supratman } \\ \text { NIM } & : \text { 100341505611 } \\ \text { Jurusan } & : \text { Pendidikan Biologi } \\ \text { Program } & : \text { Pascasarjana Universitas Negeri Malang }\end{array}$

Menyatakan dengan sebenarnya bahwa tesis yang saya buat ini benar-benar merupakan hasil karya saya sendiri, bukan merupakan pengambilan tulisan atau pikiran orang lain yang saya akui sebagai hasil tulisan atau pikiran saya sendiri.

Apabila di kemudian hari terbukti atau dapat dibuktikan tesis ini hasil jiplakan, maka saya bersedia menerima sanksi atas perbuatan tersebut.

Malang, 18 Juni 2012

Yang membuat pernyataan

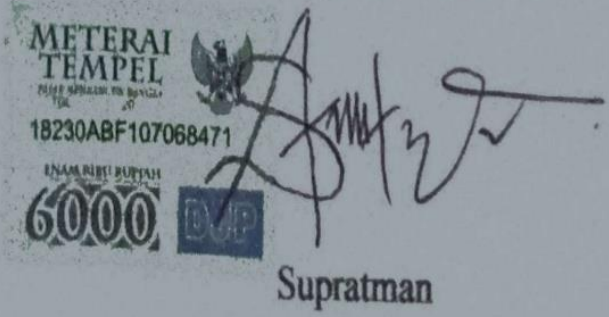




\begin{abstract}
ABSTRAK
Supratman 2012. Pengaruh Strategi Pembelajaran Berbasis Proyek Berbantuan Media DVD 6M Terhadap Kemampuan Berpikir Kritis, Pengetahuan, Sikap dan Keterampilan dalam Pengelolaan Lingkungan Pada Pembelajaran Biologi Siswa di SMAN Sumbawa, Program Studi Pendidikan Biologi Pascasarjana Universitas Negeri Malang. Pembimbing (I) Prof. Dr. Hj. Mimien Henie Irawati, M.S, dan (II) Dr. Ibrohim, M.Si
\end{abstract}

Kata Kunci: Pembelajaran berbasis proyek berbantuan media DVD 6M, kemampuan berpikir kritis, pengetahuan, sikap, dan keterampilan pengelolaan lingkungan

Permasalahan lingkungan merupakan persoalan yang sangat vital dalam kehidupan sehari-hari. Salah satu penyebab utama munculnya permasalahan lingkungan yaitu permasalahan sampah. Sampah dikenal sebagai masalah yang sulit dipecahkan terutama di kota-kota besar, sehingga akan menjadi persoalan lingkungan jika tidak segera ditangani. Salah satu cara untuk mengatasinya yaitu melalui pembudayaan konsep 6M. Media DVD 6M berisikan tentang konsep 6M merupakan suatu upaya pengelolaan sampah rumah tangga yang terdiri atas beberapa langkah yaitu: Mengurangi, Menggunakan kembali, Mengganti, Memisahkan, Mendaur ulang, dan Mengomposkan. Pembelajaran berbasis proyek memiliki peranan penting dalam pembelajaran. Penelitian ini dilakukan pada uji skala kecil yaitu sektor formal di SMAN kota Sumbawa Besar. Penelitian ini bertujuan untuk mengetahui pengaruh strategi pembelajaran berbasis proyek berbantuan media DVD $6 M$ terhadap kemampuan berpikir kritis, Pengetahuan, Sikap dan keterampilan siswa dalam pengelolaan lingkungan di SMAN Kota Sumbawa Besar. Penelitian ini bertujuan; (1) mendeskripsikan kemampuan berpikir kritis, pengetahuan, sikap dan keterampilan siswa SMAN Kota Sumbawa Besar dalam pengelolaan lingkungan, (2) Menguji pengaruh strategi pembelajaran berbasis proyek berbantuan media $D V D$ 6M terhadap kemampuan berpikir kritis, pengetahuan, dan sikap siswa di SMAN Kota Sumbawa Besar. Jumlah sampel penelitian ini sebanyak 184 orang siswa terdiri dari laki-laki sebanyak 90 orang dan perempuan sebanyak 94 orang.

Rancangan penelitian ini adalah kuasi eksperimen, dilakukan untuk memperoleh gambaran nyata mengenai pengaruh kemampuan berpikir kritis, pengetahuan, dan sikap siswa, serta memperoleh diskripsi nyata dari hasil keterampilan siswa dalam pengelolaan lingkungan di SMAN Kota Sumbawa Besar. Desain yang digunakan dalam penelitian ini adalah Pretest-Postest Control Grup Desings.

Hasil penelitian menunjukan bahwa: (1) rata-rata nilai kemampuan berpikir kritis siswa SMAN Kota Sumbawa Besar dalam pengelolaan lingkungan pada kelas eksperimen lebih tinggi daripada kelas konvensional, (2) rata-rata nilai pengetahuan siswa SMAN Kota Sumbawa Besar dalam pengelolaan lingkungan pada kelas eksperimen lebih tinggi daripada kelas konvensional, (3) rata-rata nilai sikap siswa SMAN Kota Sumbawa Besar dalam pengelolaan lingkungan pada kelas eksperimen lebih tinggi daripada kelas konvensional, (4) rata-rata nilai keterampilan kelompok siswa dalam pengelolaan sampah di SMAN Kota Sumbawa besar tergolong baik, (5) ada perbedaan kemampuan berpikir kritis 
antara siswa yang diberi pembelajaran berbasis proyek berbantuan media $D V D$ $6 \mathrm{M}$ dengan siswa yang di belajarkan pembelajaran konvensional, (6) ada perbedaan pengetahuan antara siswa yang diberi pembelajaran berbasis proyek berbantuan media DVD 6M dengan siswa yang dibelajarkan pembelajaran konvensional, (7) ada perbedaan sikap antara siswa yang diberi pembelajaran berbasis proyek berbantuan media $D V D$ 6M dengan siswa yang diajarkan pembelajaran konvensional. Berdasarkan temuan penelitian ini, beberapa saran yang dapat diajukan antara lain; (1) bahwa media DVD 6M yang digunakan dalam pembelajaran berbasis proyek dapat digunakan untuk meningkatkan kemampuan berpikir kritis sehingga dapat direkomendasikan untuk diterapkan oleh guru dalam mata pelajaran biologi maupun mata pelajaran lain yang relevan dengan kompetensi dasar yang diajarkan, (2) bahwa media DVD $6 M$ yang digunakan dalam strategi pembelajaran berabasis proyek efektif dalam meningkatkan pengetahuan, sikap dan keterampilan siswa dalam pengelolaan lingkungan, (3) bagi peneliti yang lainnya yang berminat menggunakan strategi pembelajaran berbasis proyek berbantuan media $D V D$ 6M diperlukan pengembangan peneliti lain agar penerapan media yang digunakan dan penelitian ini bermanfaat bagi mata pelajaran lain. 


\section{KATA PENGANTAR}

Puji syukur kehadirat Allah SWT yang telah menganugrahkan segala rahmat dan hidayah-Nya, sehingga penulis mendapatkan kesempatan dan kemudahan menyelesaikan penulisan tesis dengan judul “Pengaruh Strategi Pembelajaran Berbasis Proyek Berbantuan Media DVD 6M Terhadap Kemampuan Berpikir Kritis, Pengetahuan, Sikap, dan Keterampilan dalam Pengelolaan Lingkungan Pada Pembelajaran Biologi Siswa di SMAN Sumbawa" dapat terselesaikan dengan baik. Tesis ini merupakan salah satu persyaratan akademik dalam menyelesaikan program Magister pada program studi Pendidikan Biologi Pascasarjana Universitas Negeri Malang. Penulis menyadari bahwa terselesainya penulisan tesis tidak lepas dari bantuan, dorongan, arahan serta bimbingan dari pembimbing yang terhormat ibu Prof. Dr. Hj. Mimien Henie Irawati, M.S selaku pembimbing I dan Bapak Dr. Ibrohim, M.Si selaku dosen pembimbing II. Merupakan rasa terimakasih yang mendalam atas segala saran, nasehat, bimbingan, motivasi, dan keluangan waktu yang telah belio berikan. Semoga Allah memberikan balasan kebaikan yang setimpal.

Di kesempatan ini penulis menyampaikan banyak terima kasih yang tak terhingga terutama kepada pihak-pihak berikut.

1. Bapak Prof. Dr. I Nyoman Degeng M.Pd selaku Direktur Program Pascasarjana Universitas Negeri Malang yang telah memberikan fasilitas belajar dalam rangka penulis menyelesaikan studi Magister sehingga terselesaikan dengan baik.

2. Bapak Prof, Dr. agr. H. Mohammad Amin, M.Si selaku Ketua Program Studi Pendidikan Biologi Pascasarjana Universitas Negeri Malang yang telah memberikan banyak pemikiran berharga bagi penulis dan terimakasi sehingga tesis ini dapat terselesaikan dengan baik. 
3. Bapak Prof. Dr. H. Punaji Setyosari, M.Ed, sebagai penguji yang telah banyak memberikan masukan, motivasi, serta pemikiran berharga dalam penyempurnaan tesis ini.

4. Bapak Kepala Dinas Pendidikan Sumbawa Drs.H. Hasan Basri, M.Pd dan kepala Dinas BPMLH Drs. Dirmawan, kepala sekolah SMAN I Bapak Drs.Syamsul Rizal, kepalah SMAN 3 Drs. Labo Abdullah dan kepala SMAN 4 Drs. Kalsum. Serta seluruh guru dan staf yang telah memberikan bantuan selama penelitian berlangsung, terutama kepada Dra. Ratnawati, Iin Gantihar S.Pd dan Nurhidayati, S.Pd yang telah membantu dalam pelaksanaan teknis penelitian sehingga dapat terselesaikan.

5. Bapak ibu dosen program Pasca sarjana Universitas Negeri Malang telah banyak memberikan masukan yang bernilai positif dalam pelaksanaan perkuliahan berlangsung hingga berakhir.

6. Keluargaku tercinta yang telah memberikan kasih sayang yang tak terhitung nilainya, do'a, motivasi, pengertian, kesabaran, dan pengorbanan tak terhingga, sehingga pembuatan tesis ini dapat terselasikan dengan baik.

7. Semua teman-teman seperjuangan angkatan 2010 jurusan Biologi PPS UM yang telah banyak memberikan bantuan, motivasi dan kebersamaan.

Besar harapan agar tesis ini dapat bermanfaat dan memberikan pengetahuan bagi pembaca. Amin ya robbal Alamin 


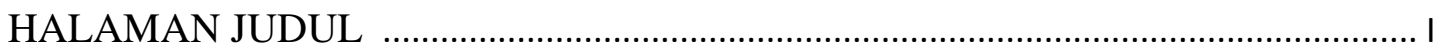

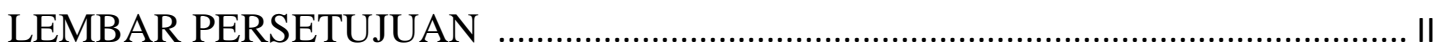

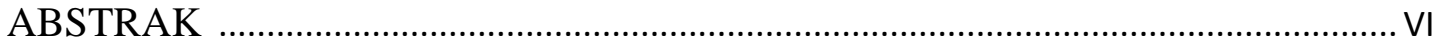

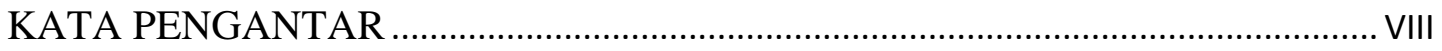

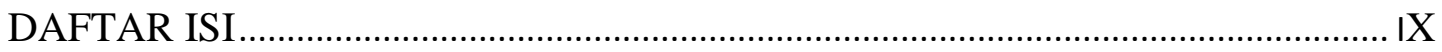

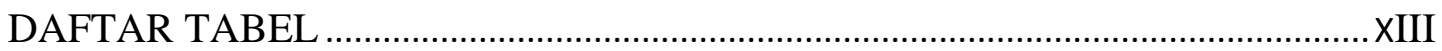

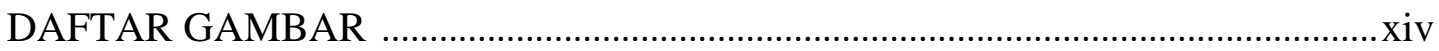

\section{BAB I PENDAHULUAN}

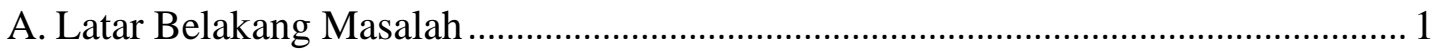

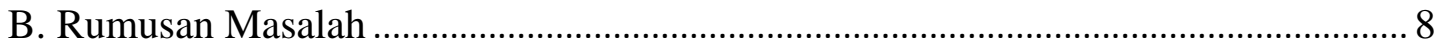

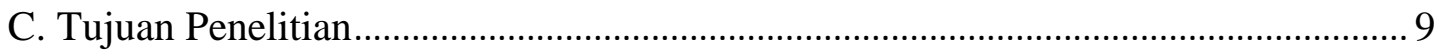

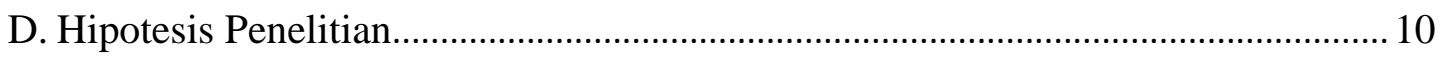

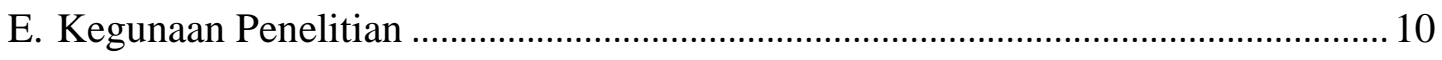

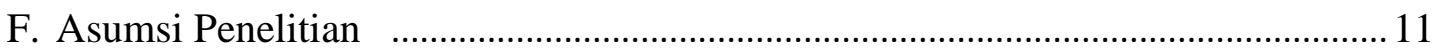

G. Ruang Lingkup dan Keterbatasan Penelitian.......................................................... 11

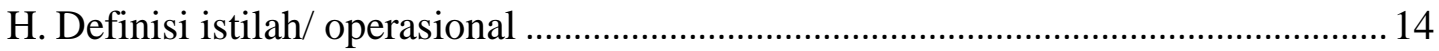

\section{BAB II KAJIAN PUSTAKA}

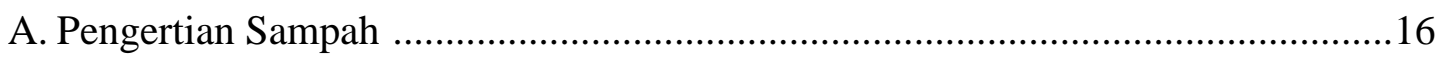

B. Klasifikasi dan Komposisi Sampah Rumah Tangga ............................................ 18

C. Faktor-faktor Yang Menentukan Timbulan dan Komposisi

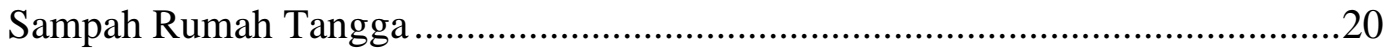

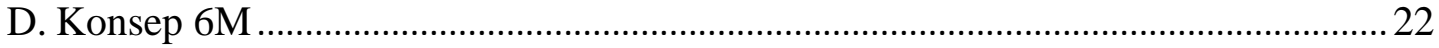

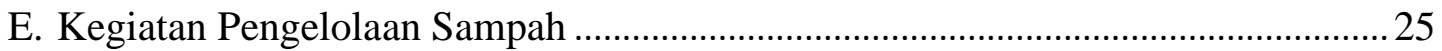

F. Paradigma Baru (transformative) Pemahaman Mengenai Sampah ......................... 26

G. Pembelajaran Berbasis Proyek Pada Mata Pelajaran Biologi $\quad$........................... 27

H. Langkah-Langkah Project Based Learning Pada Mata Pelajaran Biologi .............. 31

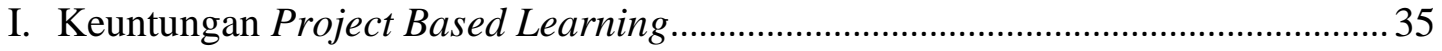

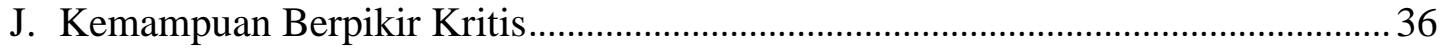

K. Pengetahuan Belajar Biologi Melalui Project Based Learning ……........................ 36

L. Sikap Siswa Terhadap Lingkungan Melalui Project Based Learning ..................... 38 
M.Keterampilan Dalam Pengelolaan Sampah......................................................... 39

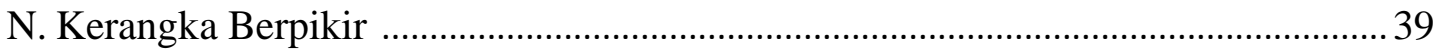

\section{BAB III METODE PENELITIAN}

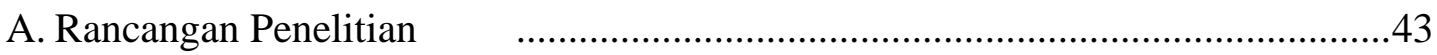

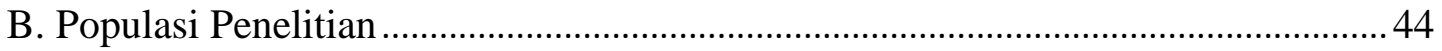

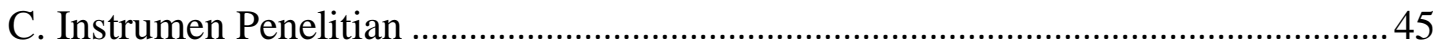

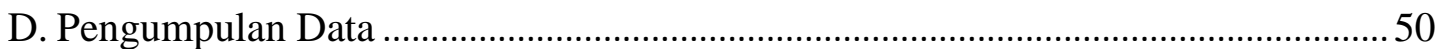

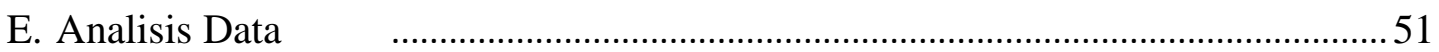

\section{BAB IV HASIL PENELITIAN}

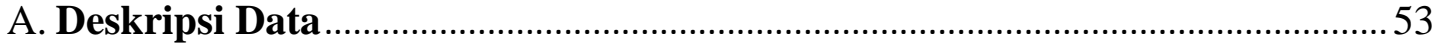

1. Keterlaksanaan Penerapan DVD 6M Melalui Project Based Learning ............. 53

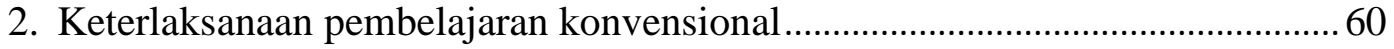

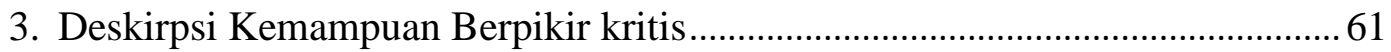

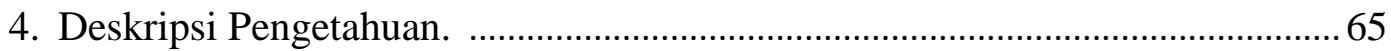

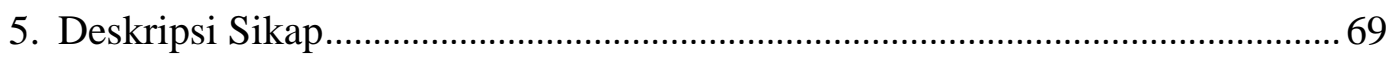

6. Deskripsi Keterampilan Siswa dalam Pengelolaan Sampah .............................. 73

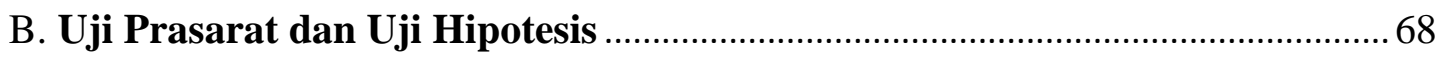

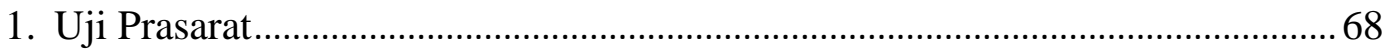

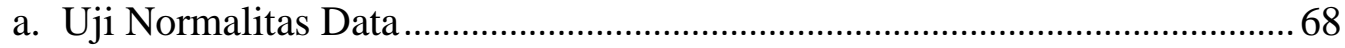

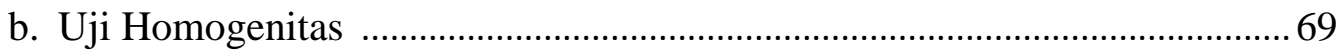

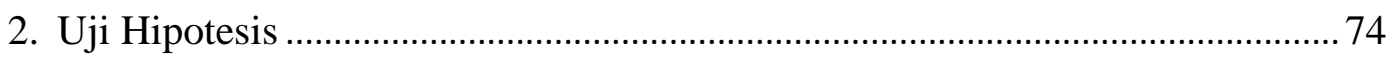

a. Pengaruh Penerapan DVD 6M melalui Project Based Learning Terhadap Kemampuan Berpikir Kritis ..................................................................... 77

b. Pengaruh Penerapan DVD 6M melalui Project Based Learning Terhadap

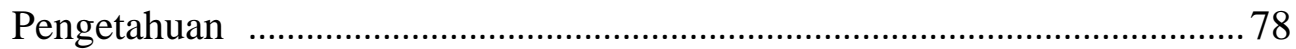

c. Pengaruh Penerapan DVD 6M melalui Project Based Learning Terhadap Sikap

d. Bagaimana keterampilan siswa dalam pengelolaan sampah melalui penerapan DVD 6M dengan Strategi Project Based Learning SMAN Kota Sumbawa Besar 


\section{BAB V PEMBAHASAN}

A. Kemampuan Berpikir kritis Siswa dalam pengelolaan sampah ............................. 82

B. Pengetahuan siswa dalam pengelolaan sampah di SMAN Sumbawa ..................... 85

C. Sikap siswa dalam pengelolaan sampah di SMAN Sumbawa ….............................. 88

D. Keterampilan Siswa dalam Pengelolaan Sampah di SMAN Sumbawa................... 90

E. Pengaruh Penerapan DVD 6M melalui Project Based Learning Terhadap Kemampuan Berpikir Kritis

F. Pengaruh Penerapan DVD 6M melalui Project Based Learning Terhadap

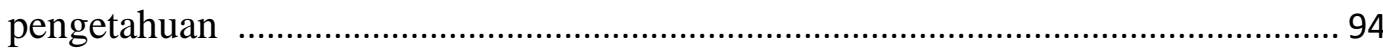

G. Pengaruh Penerapan DVD 6M melalui Project Based Learning Terhadap sikap 98

\section{BAB VI PENUTUP}

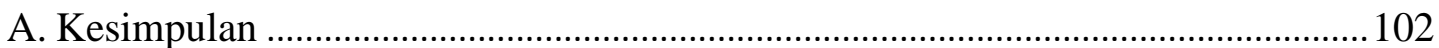

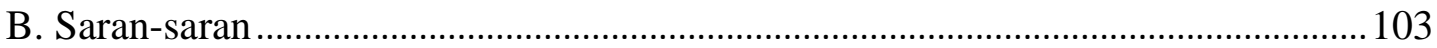

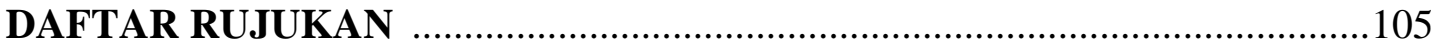




\section{DAFTAR TABEL}

Tabel

Halaman

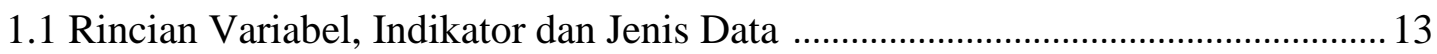

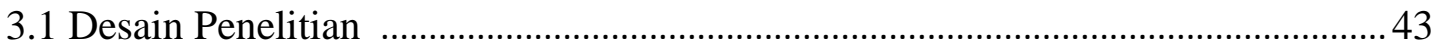

4.1 Teknik Pengumpulan Data ……………….......................................................... 51

4.1 Keterlaksanaan Penerapan DVD 6M melalui Project Based Learning .............. 60

4.2 Keterlaksanaan Pembelajaran Konvensional .......................................................... 61

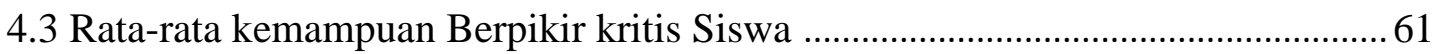

4.4 Rata-rata Nilai Indikator Kemampuan Berpikir Kritis Kelas Eksperimen ..........63

4.5 Rata-rata Nilai Setiap Indikator Kemampuan Berpikir Kritis Kelas kontrol....... 64

4.6 Rata-rata Nilai Pengetahuan Siswa Kelas Eksperimen dan Kelas Kontrol …...65

4.7 Rata-rata Nilai Setiap Indikator Pengetahuan Siswa Kelas Eksperimen...............67

4.8 Rata-rata Nilai Setiap Indikator Pengetahuan Siswa Kelas Kontrol ........................

4.9 Rata-rata Nilai Sikap Siswa SMAN Kota Sumabawa Besar ..................................69

4.10 Rata-rata Nilai Setiap Indikator Sikap Siswa Kelas Eksperimen........................ 71

4.11 Rata-rata Nilai Setiap Indikator Pengetahuan Siswa Kelas Kontrol .................. 71

4.12 Rata-rata Nilai Keterampilan Siswa dalam Pengelolaan Sampah ...................... 73

4.13 Ringkasan Uji Ancova Pengaruh Stretegi Project Based Learning Terhadap

Kemampuan Berpikir Kritis .......................................................................... 77

4.14 Rungkasan Uji LSD Kemampuan Berpikir Kritis Siswa ................................... 78

4.15 Ringkasan Uji Ancova Pengaruh Strategi Project Based Learning Terhadap

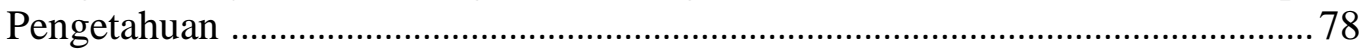

4.16 Rungkasan Uji LSD Pengetahuan Siswa .......................................................... 79

4.17 Ringkasan Uji Ancova Pengaruh Strategi Project Based Learning Terhadap

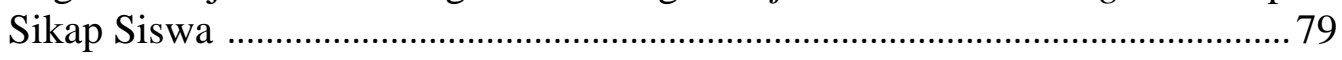

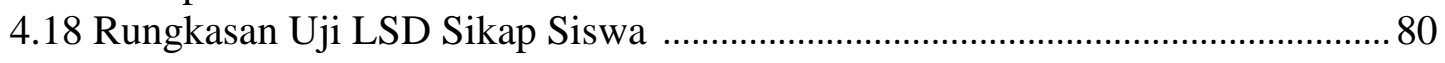

4.19 Diskripsi Statistik Keterampilan Siswa Dalam Pengelolaan Sampah ................80 


\section{DAFTAR GAMBAR}

Gambar

Halaman

1.1. Gambar Kerangka Umum Project Based Learning ........................................... 31

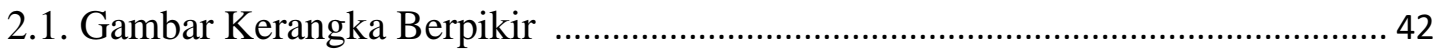

4.1. Aktivitas siswa SMAN Sumbawa Menonton DVD 6M ……………................. 54

4.2. Aktivitas Siswa Pada Perencanaan Proyek SMAN 1 ………………................. 55

4.3. Aktivitas Siswa Pada Perencanaan Proyek SMAN 3 …........................................ 56

4.4. Kegiatan Siswa Berdiskusi Menyusun Rencana Kegiatan Proyek ....................... 56

4.5. Kegiatan Anggota Kelompok Siswa Pelaksanaan Proyek ................................... 57

4.6. Kegiatan Diskusi Mengkomunikasikan Gagasan atau Temuan ......................... 58

4.7. Aktivitas Presentasi Hasil Proyek Daur Ulang Sampah ..................................... 59

4.8. Grafik Kemampuan berpikir Kritis Kelas Eksperimen dan Kelas Kontrol ......... 62

4.9. Grafik Rerata Nilai Setiap Indikator Berpikir Kritis pada Kelas Eksperimen ... 64

4.10. Grafik Rerata Nilai Setiap Indikator Berpikir Kritis Kelas kontrol .................... 65

4.11. Grafik Rerata Nilai Pengetahuan Kelas Eksperimen dan Kontrol .................... 66

4.12. Grafik Rerata Nilai Setiap Indikator Kelas Eksperimen .................................... 68

4.13. Grafik Rerata Nilai Setiap Indikator Pengetahuan Kelas Kontrol ..................... 69

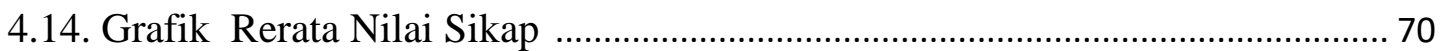

4.15. Grafik Rerata Nilai Setiap Indikator Sikap Siswa Kelas Eksperimen ............. 72

4.16. Grafik Rata-rata Nilai Setiap Indikator Pengetahuan Kelas Kontrol ................. 73 


\section{BAB I}

\section{PENDAHULUAN}

\section{A. Latar Belakang Masalah}

Permasalahan lingkungan merupakan persoalan yang sangat vital dalam kehidupan sehari-hari. Inti permasalahan lingkungan adalah hubungan makhluk hidup, khususnya manusia dengan lingkungan hidupnya. Menurut UndangUndang RI No 23 tahun 1997 lingkungan hidup adalah kesatuan ruang dengan semua benda, daya, keadaan dan makhluk hidup, termasuk di dalamnya manusia dengan perilakunya, yang mempengaruhi kelangsungan peri kehidupannya dan kesejahteraan manusia serta makhluk hidup lainnya.

Salah satu penyebab utama munculnya permasalahan lingkungan yaitu permasalahan sampah. Sampah dikenal sebagai masalah yang sulit dipecahkan terutama dikota-kota besar, Sehingga akan menjadi persoalan lingkungan di Indonesia jika tidak segera ditangani (Al Muhdhar, 1998). Selain itu akibat dari permasalahan sampah yaitu dapat menyebabkan tergangunya keseimbangan ekosistem lingkungan. Oleh karena itu diperlukan teknik pengelolaan sampah yang baik. Sampah juga di difinisikan sebagai semua jenis limbah berbentuk padat yang berasal dari kegiatan manusia dan hewan yang dibuang karena tidak bermanfaat atau tidak diinginkan lagi kehadirannya (Tchobanoglous, Theisen \& Vigil, 1993). Jumlah timbulan sampah diseluruh Indonesia di estimasikan sebesar 38,5 juta ton/tahun, dan di 26 kota Metropolitan / besar menghasilkan 14,1 juta 
ton sampah per tahun dengan total penduduk 40,1 juta (statistik persampahan Indonesia, 2008). Berdasarkan data yang di dapatkan dari Badan Pengawasan Modal dan Lingkungan Hidup (BPMLH) Kabupaten Sumbawa pada tahun 2011, jumlah timbulan sampah per hari sebanyak $388 \mathrm{~m}^{3} /$ hari dalam kapasitas Container atau sekitar $4656 \mathrm{~m}^{3} /$ tahun..

Menurut PP No. 18/1999 jo PP No. 85/1999 tentang pengelolaan limbah berbahaya dan beracun, bahwa secara umum limbah didifinisikan sebagai bahan sisa pada suatu kegiatan dan / atau proses produksi. Dalam difinisi yang terakhir aspek pembuangan sampah tidak disebutkan secara jelas, karena pada masa sekarang ada kecenderungan untuk tidak membuang sampah begitu saja, melainkan sedapat mungkin dilakukan proses daur ulang sampah, untuk menanggulangi permasalahan diatas maka salah satu cara yang dapat dilakukan dalam melakukan pengelolaan sampah yaitu melalui pemberdayaan konsep 6M.

Konsep 6M merupakan suatu upaya pengelolaan sampah rumah tangga, terdiri atas: (1) mengurangi, berarti suatu upaya mengurangi jumlah sampah yang kita timbulkan; (2) menggunakan kembali, berarti memakai atau memanfaatkan kembali sampah rumah tangga; (3) mengganti, berarti mengganti jenis bahan kebutuhan rumah tangga terutama dengan jenis bahan yang lain; (4) memisahkan, berarti memisahkan sampah rumah tangga antara sampah basah dan sampah kering yang sejenis; (5) mendaur ulang, berarti memanfaatkan kembali sampah rumah tangga dengan mengolahnya terlebih dahulu; dan (6) mengomposkan, berarti suatu upaya mengolah sampah rumah tangga menjadi kompos. Al Muhdhar (1998). 
Penelitian media $D V D 6 M$ digunakan sebagai kelanjutan dari penelitian pengembangan Al Muhdhar (2009) kemudian dalam penelitain ini peneliti melanjutkan dalam bentuk penelitian eksperimen dan diskriptif. Pada tahun 2009 telah disusun E-Media berupa softwere 6 VCD dilampiri buku saku. Hasil analisis uji validasi isi terhadap produk tersebut tergolong tinggi. 6 VCD tersebut meliputi $V C D$ pembudayaan keterampilan "mengurangi”, $V C D$ pembudayaan “ Menggunakan kembali" $V C D$ pembudayaan "Mengganti" $V C D$ pembudayaan "Memisahkan" $V C D$ pembudayaan "Mendaur ulang" dan $V C D$ pembudayaan "Mengomposkan". Hasil penelitian sebelumnya menekankan pada aspek pembudayaan yaitu aplikasi dari VCD 6M (Al Muhdhar, 1998) bahwa untuk menciptakan konsistensi antara pengetahuan dan sikap terhadap prilaku masyarakat diperlukan strategi antara lain pembudayaan 6M.

Penelitian ini di uji coba pada tingkat skala kecil yaitu jalur pendidikan formal pada siswa SMA Negeri kelas X Kota Sumbawa Besar, dengan tujuan untuk mengetahui pengaruh media DVD 6M terhadap kemampuan berpikir kritis, pengetahuan, sikap dan keterampilan siswa dalam pengelolaan sampah. Penentuan jalur pendidikan formal sangat diperlukan agar memperoleh percepatan pemahaman dan keterampilan siswa dalam pengolahan lingkungan. Dengan asumsi bahwa dalam rumah tangga terdiri atas orang tua dan anak, maka jalur pendidikan formal ditunjukan kepada anak sebagai anggota kelurga.

Pendidikan tentang pengelolaan sampah diperlukan sebagai upaya untuk mengubah prilaku manusia menjadi terampil dalam mengelolah sampah. Salah satu upaya untuk mengubah prilaku manusia menjadi terampil mengelolah sampah ialah melalui pendidikan disekolah. Berdasarkan peraturan Menteri 
Pekerjaan Umum tentang kebijakan dan strategi Nasional Pengembangan Sistem Pengelolaan Sistem Persampahan (KSNP-SPP), merupakan salah satu strategi dalam peningkatan peran aktif masyarakat untuk melaksanakan pengelolaan sampah sejak dini melalalui pendidikan bagi anak usia sekolah. Strategi ini perlu dilaksanakan secara serentak diseluruh kota di Indonesia baik tingkat SD, SMP, maupun SMA (Departemen Pekerjaan Umum, 2007).

Berdasarkan data statistik persampahan Indonesia tahun 2008 menunjukan bahwa dari 126 kota/Kabupaten di Indonesia (dalam kelompok wilayah Sumatra, Jawa, Balinusra, Kalimantan dan Samapapua) masih 57 kota/kabupaten yang memasukan program pengelolaan sampah melalui sekolah. Hal ini berarti masih kurang dari separoh kota/kabupaten memasukan masalah sampah pada kurikulum sekolah, baik monolitik maupun terintegrasi dengan mata pelajaran lain.

Di Kabupaten Sumbawa kurikulum tentang pengelolaan sampah, baik yang terintegrasi dengan mata pelajaran biologi maupun pendidikan lingkunga hidup belum diberdayakan, namun hanya sebatas membahas tentang seni budaya dan pertanian sehingga hal inilah yang menyebabkan rendahnya pengetahuan siswa dalam pengelolaan sampah. Oleh karena itu melalui mata pelajaran biologi peneliti mencoba memberikan penjelasan tentang pengelolaan sampah yaitu melalui strategi pembelajaran berbaisis proyek berbantuan media DVD 6M untuk meningkatkan kemampuan berpikir kritis, pengetahuan, sikap, dan keterampilan dalam pengelolaan lingkungan agar nantinya pembelajaran tentang pengelolaan lingkungan dapat diterapkan pada mata pelajaran lain, seperti Geografi, muatan lokal dan Pendidikan lingkungan Hidup. 
Penelitian tentang pengelolaan sampah pada pendidikan formal perna dilakukan oleh Jurczak,et al.(2003 dalam Setiowati, 2011) bahwa program pendidikan tentang sampah disekolah berdampak positif bagi pengetahuan peserta didik khususnya tentang isu-isu sampah. Program pendidikan tentang sampah juga memberi kesempatan kepada orang tua untuk berdiskusi dengan anaknya mengenai masalah sampah, serta dampaknya terhadap perubahan sikap dan prilaku peserta didik terhadap sampah dirumah. Guru juga menganggap bahwa program pendidikan tentang sampah adalah positif, mengusulkan pelaksanaannya sebagai solusi ideal untuk masalah sampah Nasional.

Penelitian lain tentang pengelolaan sampah melalui pembelajaran Geografi dalam upaya menuju manifestasi dan prilaku positif peserta didik telah diteliti oleh Hapsari (2006). Hasil penelitian menunjukan bahwa pembelajaran Geografi merupakan salah satu mata pelajaran yang ternyata berhasil mendidik peserta didik dalam mengelola sampah.

Program pengelolaan sampah di sekolah sebaiknya dirancang dengan melibatkan keluarga sehingga mampu meningkatkan pengetahuan, sikap, dan prilaku peserta didik. Sebagai generasi penerus, sikap peserta didik terhadap lingkungan menjadi penting karena secara langsung akan memainkan peranan dalam memberikan solusi untuk masa depan lingkungan kita. Selain ditunjukan kepada peserta didik, program pengelolaan sampah dapat juga ditunjukan kepada orang dewasa yaitu guru dan anggota keluarga Jurczak,et al. (2003 dalam Setiowati, 2011).

Kemajuan teknologi yang pesat bersifat ambivalen, dapat memberikan kemaslahatan dan kemudharatan bagi masyarakat. Oleh karena itu peserta didik se- 
bagai anggota masyarakat dan keluarga perlu diberi pengalaman dalam membahas permasalahan atau isu terkait sains (sampah) dan teknologi (pengolahan sampah) yang ada dimasyarakat, sehingga peserta didik menjadi paham. Melalui pembelajaran yang mengaitkan antara sains, teknologi dan masyarakat, peserta didik akan dapat memiliki pengetahuan dan kearifan dalam menyikapi persoalan teknologi yang semakin hari semakin berkembang.(Setiowati, 2011).

Pengelolaan lingkungan dalam penelitian ini merupakan bagian dari mata pelajaran biologi pada kompetensi dasar adalah menjelaskan keterkaitan antara kegiatan manusia dengan masalah kerusakan lingkungan serta menganlisis jenis limbah dan daur ulang limbah. Untuk mebelajarkan materi tersebut maka salah satu strategi untuk memahamkan siswa tentang pentingnya pengelolaan lingkungan yaitu dengan menggunakan strategi pembelajaran berbasis proyek berbantuan media DVD $6 M$.

Pembelajaran berbasis proyek adalah sebuah pembelajaran inovatif yang menekankan belajar kontekstual melalui kegiatan-kegiatan yang komplek. Fokus dari pembelajaran ini terletak pada konsep-konsep dan prinsip inti dari suatu disiplin studi, melibatkan pembelajaran dan investigasi pemecahan masalah dan kegiatan tugas-tugas bermakna yang lain, memberi kesempatan pembelajar bekerja secara otonom untuk mengkonstruk pengetahuan mereka sendiri, dan mengkomunikasikannya dalam proyek nyata Nurhadi, (2003 dalam Mahanal, 2009). Selain itu pembelajaran berbasis proyek merupakan pembelajaran yang di desain untuk persoalan yang kompleks dimana siswa melakukan investigasi untuk memahaminya, menekankan pembelajaran dengan aktivitas yang lama, tugas yang diberikan pada siswa bersifat multidisiplin, dan berorentasi pada produk (artifak). 
Landasan utama dari pembelajaran berbasis proyek tidak terlepas dari pembelajaran kontekstual, pembelajaran Inkuiri dan pembelajaran kooperatif.

Menurut porworeni (2004) ada bebrapa hal yang mendasari mengapa pembelajaran berbasis proyek diterapkan yaitu selama ini pembelajaran masih berpusat pada guru, siswa menjadi sangat tergantung pada guru sehingga siswa tidak terbiasa melihat alternatif lain yang mungkin dapat dipakai dalam menyelesaikan suatu masalah secara efektif dan efiesien. Akhirnya siswa hanya menghapal saja semua konsep atau rumus tanpa memahami maknanya dan tidak mampu menerapkannya dalam berbagai situasi aplikatif. Dan kreatifitas pembelajaran tidak hanya bertumpuh pada guru, akan tetapi sudah waktunya siswa diberi kesempatan untuk mengembangkan sendiri pengetahuanya tanpa menghilangkan peran guru sebagai fasilitator dan klarifikator.

Beberapa hasil penelitian yang menunjukan keefektifan multimedia terhadap pembelajaran telah dilakukan oleh beberapa peneliti terdahulu. Susilowati, dkk. (2010), bahwa produk software E-Media VCD 6M yang dilampiri buku saku, efektif sebagai media pendidikan kepada masyarakat dalam pengelolaan sampah rumah tangga, dapat meningkatkan pemahaman dan keterampilan masyarakat baik melalui jalur pendidikan formal maupun jalur pendidikan non formal.

Berdasarkan pandangan dan identifikasi masalah yang telah diuraikan diatas perlu diupayakan penerapan strategi pembelajaran berbasis proyek berbantuan media DVD 6M terhadap kemampuan berpikir kritis, pengetahuan, sikap dan keterampilan siswa dalam pengelolaan sampah pada mata pelajaran Biologi di SMA Negeri Kota Sumbawa Besar. 


\section{B. Rumusan Masalah}

Permasalahan merupakan pernyataan yang lengkap dan rinci mengenai ruang lingkup masalah yang akan diteliti. Berdasarkan pemaparan latar belakang di atas maka masalah penelitian yang akan di jawab pada penelitian ini adalah sebagai berikut.

1. Bagaimana kemampuan berpikir kritis siswa SMAN Kota Sumbawa Besar dalam pengelolaan lingkungan?

2. Bagaimana pengetahuan siswa SMAN Kota Sumbawa Besar dalam pengelolaan lingkungan?

3. Bagaimana sikap siswa SMAN Kota Sumbawa Besar dalam pengelolaan lingkungan?

4. Bagaimana keterampilan siswa SMAN Kota Sumbawa Besar dalam pengelolaan sampah?

5. Adakah pengaruh strategi pembelajaran berbasis proyek berbantuan media DVD 6M terhadap kemampuan berpikir kritis siswa SMAN Kota Sumbawa Besar dalam pengelolaan lingkungan?

6. Adakah pengaruh strategi pembelajaran berbasis proyek berbantuan media DVD 6M terhadap pengetahuan siswa SMAN Kota Sumbawa Besar dalam pengelolaan lingkungan?

7. Adakah pengaruh strategi pembelajaran berbasis proyek berbantuan media DVD 6M terhadap sikap siswa SMAN Kota Sumbawa Besar dalam pengelolaan lingkungan? 


\section{Tujuan Penelitian}

Berdasarkan rumusan masalah diatas maka tujuan dalam penelitian ini adalah sebagai berikut.

1. Mendeskripsikan kemampuan berpikir kritis siswa SMAN Kota Sumbawa Besar dalam pengelolaan lingkungan.

2. Mendeskripsikan pengetahuan siswa SMAN Kota Sumbawa Besar dalam pengelolaan lingkungan.

3. Mendeskripsikan sikap siswa SMAN Kota Sumbawa Besar dalam pengelolaan lingkungan.

4. Mendeskripsikan keterampilan siswa dalam pengeloaan sampah SMAN Kota Sumbawa Besar.

5. Menguji pengaruh strategi pembelajaran berbasis proyek berbantuan media DVD 6M terhadap kemampuan berpikir kritis siswa SMA Kota Sumbawa Besar dalam pengelolaan lingkungan.

6. Menguji pengaruh strategi pembelajaran berbasis proyek berbantuan media DVD 6M terhadap pengetahuan siswa SMAN Kota Sumbawa Besar dalam pengelolaan lingkungan.

7. Menguji pengaruh strategi pembelajaran berbasis proyek berbantuan media DVD 6M terhadap sikap siswa SMA Kota Sumbawa Besar dalam pengelolaan lingkungan. 


\section{Hipotesis Penelitian}

Hipotesis dalam penelitian adalah sebagai berikut.

1. Terdapat perbedaan kemampuan berpikir kritis antara siswa yang diberi strategi pembelajaran berbasis proyek berbantuan media $D V D 6 \mathrm{M}$ dengan yang diberi pembelajaran konvensional.

2. Terdapat perbedaan pengetahuan antara siswa yang diberi strategi pembelajaran berbasis proyek berbantuan media $D V D$ 6M dengan yang diberi pembelajaran konvensional.

3. Terdapat perbedaan sikap antara siswa yang diberi strategi pembelajaran berbasis proyek berbantuan media $D V D 6 \mathrm{M}$ dengan yang diberi pembelajaran konvensional.

\section{E. Kegunaan Penelitian}

Kegunaan yang diharapkan dari hasil penelitian ini dapat dijelaskan sebagai berikut.

1. Bagi peneliti

Bagi yang berminat menggunakan strategi pembelajaran berbasis proyek berbantuan media $D V D$ 6M maka diperlukan pengembangan peneliti lainnya agar penerapan perangkat pembelajaran dan produk yang diterapkan ini dapat digunakan untuk meningkatkan kemampuan berpikir kritis, pengetahuan, sikap dan keterampilan siswa dan bisa diterapkan mata pelajaran lain.

2. Bagi sekolah

Khususnya SMAN Kota Sumbawa Besar bahwa media DVD $6 M$ yang digunakan dalam strategi pembelajaran berbasis proyek hendaknya dapat digunakan untuk meningkatkan kemampuan berpikir kritis, pengetahuan, sikap 
dan keterampilan siswa dalam pengelolaan lingkungan agar memiliki mutu yang lebih baik dari sebelumnya sebagai bentuk pelayanan kepada siswa dan hasil penelitian dapat diguanakan sebagai acauan kedepan.

3. Bagi Guru biologi

Guru mata pelajaran biologi hendaknya dapat menggunakan hasil penelitian ini berupa perangkat pembelajaran agar kiranya melalui perangkat pembelajaran yang terdapat dalam karya ilmia ini mampu memberdayakan kemampuan berpikir krtis, pengetahuan, sikap dan keterampilan siswa dalam pengelolaan lingkungan.

\section{F. Asumsi Penelitian}

Asumsi dalam penelitian ini adalah sebagai berikut.

1. Kemampuan berpikir kritis siswa dalam pengelolan sampah diukur dengan teknik tes soal bentuk uraian kemampuan berpikir kritis.

2. Pengetahuan siswa dalam penelitian ini diukur dengan teknik tes bentuk soal uraian tes pengetahuan yang disusun berdasarkan indikator pengetahuan.

3. Sikap siswa dalam pengelolaan sampah dapat di ukur dengan teknik tes bentuk uraian yang disusun berdasarkan indikator sikap.

4. Keterampilan siswa dalam pengelolaan sampah dapat diukur dengan hasil laporan produk untuk mengetahui keterampilan siswa dalam pengelolaan sampah dan tugas proyek disusun berdasarkan indikator keterampilan.

\section{G. Ruang Lingkup dan Keterbatasan Penelitian}

Ruang lingkup dalam penelitian ini yaitu penelitian eksperimen semu (kuasi-eksperimen). Penelitian ini dimaksud untuk mengungkapkan ada tidaknya 
pengaruh strategi pembelajaran berbasis proyek berbantuan media $D V D$ 6M terhadap kemampuan berpikir kritis, pengetahuan, sikap dan keterampilan siswa dalam pengelolaan sampah. Variabel bebas dalam penelitian ini adalah penerapan strategi pembelajaran berbasis proyek berbantuan media $D V D 6 \mathrm{M}$ dan variabel terikat yaitu kemampuan berpikir kritis, pengetahuan, sikap dan keterampilan siswa dalam pengelolaan sampah. Sedangkan variabel kontrol dalam penelitian ini yaitu meliputi kemampuan guru, waktu guru mengajar, materi belajar dan evaluasi.

Keterbatasan yang terdapat dalam penelitian ini adalah sebagai berikut.

1. Penelitian ini terbatas pada siswa kelas X SMAN Kota Sumbawa Besar semester II tahun pelajaran 2011/2012 pada standar kompetensi menganalisis hubungan antara komponen ekosistem, perubahan materi dan energi serta peranan manusia dalam keseimbangan ekosistem.

2. Teknik penelitian eksperimen memerlukan ketelitian yang matang sebab menggunakan data dalam bentuk statitik. Sehingga diperlukan kejelihan atau ketelitian yang matang dalam mengelola data.

3. Terkait dengan kajian atau sumber refrensi tentang DVD 6M masih minim dan buku-buku yang didapatkan terbitannya kurang up to date.

Variabel-variabel yang digunakan dalam penelitian ini secara lebih rinci dapat dijabarkan seperti tertera pada Tabel 1.1 
Tabel 1.1 Rincian Variabel, Indikator dan Jenis Data

\begin{tabular}{|c|c|c|}
\hline Variabel & Indikator & $\begin{array}{c}\text { Jenis Data / } \\
\text { Instrumen }\end{array}$ \\
\hline $\begin{array}{l}\text { Variabel Bebas: } \\
\text { a. } D V D 6 \mathrm{M}\end{array}$ & $\begin{array}{l}\text { a. Mengurangi } \\
\text { b. Menggunakan kembali } \\
\text { c. Mengganti } \\
\text { d. Memisahkan } \\
\text { e.Mendaur ulang } \\
\text { f.Memengomposkan }\end{array}$ & Nominal \\
\hline $\begin{array}{l}\text { b. Project } \\
\text { Based } \\
\text { Learning } \\
\text { berbantuan } \\
6 \mathrm{M}\end{array}$ & $\begin{array}{l}\text { a. Planning } \\
\text { 1) Memilih topik } \\
\text { 2) Merancang pekerjaan } \\
\text { 3) Mengorganisir pekerjaan } \\
\text { b. Creating } \\
\text { 1) Bekerjasama dengan yang lain } \\
\text { (Pelaksanaan proyek) } \\
\text { 2) Mengembangkan pemikiran dan } \\
\text { dokumentasi } \\
\text { c. Processing } \\
\text { 1) Presentasi laporan proyek } \\
\text { 2) Refleksi, tindak lanjut dan evaluasi }\end{array}$ & Nominal \\
\hline $\begin{array}{l}\text { c. Pembelajaran } \\
\text { Konvensional }\end{array}$ & $\begin{array}{l}\text { a. Pendahuluan (apersepsi) } \\
\text { b. Inti: penyampaian materi secara langsung } \\
\text { dengan metode ceramah, diskusi atau tanya } \\
\text { jawab. } \\
\text { c. Penutup:evaluasi }\end{array}$ & Nominal \\
\hline $\begin{array}{l}\text { Variabel terikat: } \\
\text { a. Kemampuan } \\
\text { berpikir kritis }\end{array}$ & $\begin{array}{l}\text { a. Kemampuan berpendapat } \\
\text { b. Kemampuan memberikan alasan } \\
\text { c. Kemampuan mengelompokan } \\
\text { d. Kemampuan menjeleskan sebab akibat } \\
\text { e. Kemampuan menganalisis }\end{array}$ & Interval \\
\hline b. Pengetahuan & $\begin{array}{l}\text { a. Mengingat (C1) } \\
\text { b. Memahami (C2) } \\
\text { c. Menerapakan (C3) } \\
\text { d. Menganalisis (C4) } \\
\text { e. Mengevaluasi (C5) } \\
\text { f. Menciptakan (C6) }\end{array}$ & Interval \\
\hline c. Sikap & $\begin{array}{l}\text { a. Kognisi (Menerima (A1), Menanggapi (A2), } \\
\text { Menilai (A3) } \\
\text { b. Afeksi (Menilai (A3), Mengorganisasi (A4) } \\
\text { c. Konasi (Mengorganisasi (A4), Menjadikan pola } \\
\text { hidup (A5). }\end{array}$ & Interval \\
\hline $\begin{array}{l}\text { d. Keterampilan } \\
\text { Siswa dalam } \\
\text { Pengelolaan } \\
\text { sampah }\end{array}$ & $\begin{array}{l}\text { a. Keterampilan mengurangi sampah } \\
\text { b. Keterampilan menggunakan kembali sampah } \\
\text { c. Keterampilan mengganti sampah } \\
\text { d. Keterampilan memisahkan sampah } \\
\text { e. Keterampilan mendaur ulang sampah } \\
\text { f. Keterampilan mengomposkan sampah }\end{array}$ & Interval \\
\hline
\end{tabular}




\section{H. Definisi Istilah/Operasional}

1. Media DVD $6 \mathrm{M}$ merupakan softwere yang berisi konsep dan teknik pengelolaan sampah rumah tangga melalui pembudayaan $6 \mathrm{M}$ yaitu Mengurangi, Menggunakan kembali, Mengganti, Memisahkan, Mendaur ulang dan Mengomposkan. Instrument yang digunakan yaitu rubrik laporan produk.

2. Pembelajaran berbasis proyek adalah suatu strategi pembelajaran yang didesain untuk persoalan yang kompleks dimana siswa melakukan investigasi untuk memahaminya, menekankan pembelajaran dengan aktivitas yang lama, tugas yang diberikan pada siswa bersifat multidisiplin, dan berorentasi pada produk (artifak). Tahapan pembelajaran berbasis proyek dalam pembelajaran biologi meliputi tahap Planning yaitu tahapan merencanakan seluruh proyek, mempersiapkan proyek, mengorganisir pekerjaan, kegiatan didalamnya yaitu memilih topik, merancang proyek, mengorganisir pekerjaan. Tahap Creating, terdiri atas mengembangkan gagasan proyek, aktifitas pengembangan dan dokumentasi, dan menghasilkan suatu produk untuk dipresentasikan di dalam kelas. Tahap Processing meliputi presentasi proyek dan evaluasi.

3. Kemampuan berpikir kritis siswa merupakan skor yang dicapai siswa dari hasil tes tulis dalam bentuk essay yang mencakup kemampuan berpendapat, memberi alasan, mengelompokan, sebab akibat, menganalisis. Kemampuan berpikir kritis dalam penelitian ini diukur dengan teknik tes bentuk uraian.

4. Pengetahuan dalam penelitian ini merupakan pengetahuan siswa yang diukur dengan menggunakan isntrumen berupa soal-soal tes. Macam-macam soal disusun berdasarkan indikator pengetahuan yaitu mengingat $(\mathrm{C} 1)$, memahami (C2), menerapkan (C3), menganalisis (C4), mengevaluasi (C5), menciptakan 
(C6). Pengetahuan dalam penelitian ini diukur dengan menggunakan teknik tes bentuk uraian.

5. Sikap merupakan hasil belajar dan memuat kecendrungan untuk mengadakan penilaian terhadap individu tertentu, obyek tertentu, kejadian atau situasi tertentu dan akan bertindak sesuai hasil evaluasi tersebut. Soal yang diberikan dalam penelitian berupa soal uraian yang disusun berdasarkan indikator sikap yaitu kognisi terkait sikap siswa dalam menerima (A1), menanggapi (A2), menilai (A3). Kemudian afeksi yaitu sikap siswa dalam menilai (A3), mengornasisasi (A4), dan konasi yaitu sikap siswa dalam mengorganisasi (A4) dan menjadikan pola hidup (A5). Sikap dalam penelitian ini diukur dengan teknik tes bentuk uraian dan lembar pengamatan tes sikap.

6. Keterampilan siswa dalam pengelolaan sampah yang meliputi keterampilan pembudayaan 6M yaitu keterampilan siswa dalam mengurangi sampah, keterampilan menggunakan kembali sampah, keterampilan menggantikan sampah, keterampilan memisahkan sampah, keterampilan mendaur ulang sampah, dan keterampilan mengomposkan sampah. Keterampilan siswa dalam penelitian ini dapat diukur dengan penilaian laporan produk. 


\section{BAB II}

\section{KAJIAN PUSTAKA}

\section{A. Pengelolaan Lingkungan}

Pengelolaan tentang lingkungan hidup di Indonesia telah dimulai sejak tahun 1960-an. Lingkungan diartikan sebagai bulatan yang melingkupi atau yang melingkari sekalian yang terlingkung dari suatu daerah sekitarnya. Neolaka, (dalam Nasution 2008). Sedangkan menurut inseklopedia umum (1977) lingkungan adalah alam sekitar termasuk orang-arangnya dalam hidup pergaulan yang mempengaruhi manusia sebagai anggota masyarakat dalam kehidupan dan kebudayaan. Menurut Undang-undang RI No 4 tahun 1982, tentang ketentuanketentuan pokok pengelolaan lingkungan hidup dan Undang-Undang RI No 23 tahun 1997 tentang pengelolaan lingkungan hidup bahwa lingkungan hidup merupakan kesatuan ruang dengan semua benda, daya keadaan dan mahluk hidup termasuk manusia dan perilakunya yang mempengaruhi kelangsungan perikehidupan dan kesejahteraan manusia serta mahluk hidup lainnya.

Penjelasan pasal tersebut dapat diartikan bahwa lingkungan hidup merupakan sistem yang meliputi lingkungan alam, lingkungan buatan, dan lingkungan sosial yang mempengaruhi kelangsungan perikehidupan dan kesejahteraan manusia serta mahluk hidup lainnya. Oleh karena itu keberadaan lingkungan hidup harus turut dipertimbangkan dalam setiap pengelolaan suatu kegiatan manusia termasuk pengelolaan sampah. Karena lingkungan hidup 
manusia adalah sistem dimana terdapatnya kepentingan manusia didalamnya. Soerjadic (1998 dalam Nasution 2008). Berdasarkan pengertian pengelolaan lingkungan hidup yang telah diuraikan diatas, maka pengelolaan sampah pun harus dikaitkan dengan upaya memelihara dan meningkatkan kualitas lingkungan. Artinya pengelolaan sampah hendaknya merupakan upaya dalam pendayagunaan, pengawasan, dan pengendalian sampah, serta pemulihan lingkungan akibat pencemaran sampah

\section{B. Pengertian Sampah}

Menurut Departemen Pekerjaan Umum (1990b) sampah berarti limbah yang bersifat padat (Solid waste) terdiri dari zat organik dan zat anorganik yang dianggap tidak berguna lagi dan harus dikelolah agar tidak membahayakan lingkungan dan melindungi investasi pembangunan. Sampah rumah tangga meliputi seluruh macam material atau obyek yang oleh suatu keluarga dapat disisikan kedalam tempat sampah (Al Muhdhar 2006). Sampah sebagai hasil kegiatan manusia tidak harus dibaung tetapi dikelolah agar tidak mengganggu kesehatan lingkungan dan berfungsi sebagai sumber daya ekonomi. Oleh karena itu bukan lagi "buang sampah pada tempatnya" tetapi “ kumpulkan sampah pada tempatnya ".

Sampah juga didifinisikan sebagai semua jenis limbah berbentuk padat yang berasal dari kegiatan manusia dan hewan, dan dibuang karena tidak bermanfaat atau tidak diinginkan legi kehadirannya (Tchobanoglous, Theisen \& Vigil, 1993). Sedangkan dalam PP No. 18/1999 jo PP No. 85/1999 tentang pengelolaan limbah berbahaya dan beracun, secara umum limbah didifinisikan sebagai bahan sisa pada suatu kegiatan dan/atau proses produksi. Dalam difinisi yang terakhir aspek 
pembuangan tidak disebutkan secara jelas, karena pada masa sekarang ada kecenderungan untuk tidak membuang sampah begitu saja, melainkan sedapat mungkin melakukan daur ulang. Pada kenyataannya tidak semua sampah yang dibuang oleh manusia tergolong tidak mempunyai nilai guna lagi, sebab masih banyak karakteristik yang masih dapat dimanfaatkan, seperti berikut.

a. Sampah basah memiliki kandungan protein, lemak, karbohidrat, serat, dan nutrient lainya, serta nilai kalori yang potensial untuk dijadikan pupuk organic / kompos, makanan ternak, dan sumber energi.

b. Sampah plastik terdiri atas berbagai jenis polimer plastik yang berbeda, yang masing-masing dapat diolah dan dimanfaatkan kembali

c. Sampah kertas terdiri atas berbagai jenis komponen kertas yang dapat diolah dan dimanfaatkan kembali.

d. Sampah logam terdiri atas berbagai jenis komponen logam yang dapat diolah dan dimanfaatkan kembali.

\section{Klasifikasi dan Komposisi Sampah Rumah Tangga}

Menurut Al Muhdhar (2006) sampah dikelompokkan ke dalam sampah kota, sampah industri dan sampah pertanian. Sampah kota dalam beberapa literatur juga disebut "town refuse" dan "munisipal refuse" terdiri atas sampah jalan dan sampah pasar, sampah perkantoran, sampah industri, sampah tempat rekreasi, sampah taman, sampah rumah sakit, dan sampah rumah tangga. Sampah rumah tangga juga dapat digolongkan kedalam sampah berbahaya dan tidak berbahaya. Al Muhdhar (2006) mengklasifikasikan sampah rumah tangga kedalam klasifikasi limbah domestic. Limbah domestic yaitu semua benda atau produk sisa dalam bentuk cair atau padat karena kegiatan manusia yang telah 
dianggap tidak berguna lagi dan tidak dikehendaki oleh pemiliknya yang kemudian biasanya akan dibuang yang berasal bukan dari industri melainkan dari kantor, restoran, tempat ibadah, tempat hiburan, pertokoan, pelabuhan, rumah sakit, dan dari rumah tangga.

Limbah rumah tangga munurut Al Muhdhar (2006) dapat digolongkan dalam tiga bentuk yaitu.

a. Limbah padat atau sampah, sebagian besar berasal dari dapur dan sebagian kecil dari rumah. Limbah padat ini berupa bahan organik umumnya mudah didegradasi dan dapat juga anorganik yang sulit atau sama sekali tidak dapat didegradasi.

b. Limbah cair, terutama berasal dari kamar mandi, WC, dan kamar tempat cuci pakaian. Dalam limbah cair ini ditemukan adanya deterjen yang susah didegradasi.

c. Limbah gas, berasal dari dapur, penggunaan produk-produk keemasan aerosol misalnya insektisida, parfum yang mengandung CFC, dan lain-lain.

Menurut (SNI 13-1990-F), sampah didifinisikan sebagai limbah yang bersifat padat, terdiri dari zat organic dan zat anorganik yang dianggap tidak berguna lagi dan harus dikelola agar tidak membahayakan lingkungan dan melindungi investasi pembangunan. Menurut UU No. 18 tahun 2008, sampah ialah sisa kegiatan sehari-sehari manusia dan/atau proses alam yang berbentuk padat.

Pada kenyataannya tidak semua sampah yang dibuang oleh manusia tergolong tidak mempunyai nilai guna lagi, karena masih memiliki karakteristik yang masih dapat dimanfaatkan, seperti: (1) sampah basah memiliki kandungan 
protein, lemak, karbohidrat, serat, dan nutrient lainya, serta nilai kalori yang potensial untuk dijadikan pupuk organik/kompos, makanan ternak, dan sumber energi, (2) sampah plastik terdiri atas berbagai jenis polimer plastik yang berbeda, yang masing-masing dapat diolah dan dimanfaatkan kembali, (3) sampah kertas terdiri atas berbagai jenis komponen kertas yang dapat diolah dan dimanfaatkan kembali, dan (4) sampah logam: terdiri atas berbagai jenis komponen logam yang dapat diolah dan dimanfaatkan kembali Al Muhdhar, (2006).

\section{Faktor-Faktor yang Menentukan Timbulan dan Komposisi Sampah Rumah Tangga}

Timbulan dan komposisi sampah rumah tangga menurut Al Muhdhar (2006) ditentukan oleh beberapa faktor berikut.

1. Jumlah dan tingkat pertumbuhan penduduk sebagai akibat timbulan sampah rumah tangga di Indonesia memperlihatkan bahwa semakin besar jumlah penduduk suatu kota semakin besar pula timbulan sampahnya.

2. Tingkat pendapatan dan pola konsumsi masyarakat dan pola penyedian kebutuhan hidup. Departemen Pekerjaan Umum (1991 a) dalam Al Muhdhar (2006) menyatakan bahwa semakin tinggi tingkat sosial ekonomi seseorang maka timbulan sampah rumah tangga yang dihasilkan semakin besar. Pendapat diatas didukung oleh pendapat Al Muhdhar (2006) yang menyatakan bahwa semakin mapan kehidupan makin besar limbah rumah tangga yang dihasilkan. Tetapi semakin mapan kehidupan ekonomi rumah tangga semakin sedikit limbah organik yang dihasilkan. Hal tersebut disebabkan rumah tangga mapan makin banyak mengkonsumsi makanan siap pakai, misalnya makanan dalam kaleng. Hal itu menyebabkan komposisi sampah rumah tangga berubah dari 
organik menjadi anorganik. Keanekaragaman komposisi sampah pada keluarga mapan lebih banyak dari pada keluarga sederhana. Hal ini disebabkan rumah tangga mapan terbiasa memenuhi kebutuhan hidup yang bukan primer lagi, sehingga akan mempengaruhi keanekaragaman komposisi sampah kota.

\section{Musim}

Timbulan sampah rumah tangga dimusim hujan lebih besar daripada timbulan sampah rumah tangga dimusim kemarau. Selain itu musim buah-buahan juga berkaitan erat dengan timbulan dan komposisi sampah rumah tangga.

Menurut Neolaka (2008, dalam Setowati 2011). Timbulan dan kualitas sampah dipengaruhi oleh beberapa faktor antara lain penduduk yang jumlahnya bertambah pesat, keadaan sosial ekonomi, dan kemajuan ilmu pengetahuan dan teknologi (Iptek). Pengelolaan sampah harus memperhatikan laju pertumbuhan penduduk, tingkat sosial akonomi penduduk, dan teknologi yang berkembang begitu cepat. Dengan demikian, pengelolaan sampah diperlukan untuk menghindari /mencegah timbulnya penyakit, tidak merusak lingkungan, mencega merusaknya estitika dan konservasi sumber daya alam.

Timbulan sampah ialah sampah yang dihasilkan oleh aktifitas dalam kurun waktu tertentu, atau dengan kata lain banyaknya sampah yang dihasilkan dalam satuan berat (kilogram) gravimetri atau volume (liter) volumetri (Tchobanoglous dalam Al Muhdhar, 1998). Satuan timbulan sampah ialah banyaknya sampah dalam (1) satuan berat, kilogram per orang per-hari (kg/orang/hari), (2) satuan volume: liter per orang per-hari ( $\mathrm{kg} / \mathrm{orang} / \mathrm{hari})$. 


\section{E. Konsep 6M dalam Mengatasi Permasalahan Sampah}

Al Muhdhar (1998) menemukan 6M merupakan suatu upaya pengelolaan sampah rumah tangga yang terdiri atas beberapa langkah yaitu: Mengurangi, Menggunakan kembali, Mengganti, Memisahkan, Mendaur ulang, dan Mengomposkan. Mengurangi berarti suatu upaya mengurangi jumlah sampah yang kita timbulkan; menggunakan kembali berarti memakai atau memanfaatkan kembali sampah rumah tangga; Mengganti berarti mengganti jenis bahan kebutuhan rumah tangga tertentu dengan jenis bahan yang lain; Memisahkan berarti memisahkan sampah rumah tangga antara sampah basah dan sampah kering, yang sejenis; Mendaur ulang berarti memanfaatkan kembali sampah rumah tangga dengan mengelola terlebih dahulu; Mengomposkan berarti suatu upaya mengelolah sampah rumah tangga menjadi kompos.

Manfaat 6M antara lain dapat mengurangi jumlah sampah yang ditimbulkan oleh setiap rumah tangga, sehingga dapat mengurangi timbulan sampah kota. Cara-cara mensukseskan 6M dicontohkan dalam penelitain sebelumnya sebagai berikut.

\section{Mengurangi}

Yang dimaksud mengurangi yaitu: (1) berbelanja lebih berhati-hati; (2) membuat lebih banyak makanan dirumah sebagai pengganti membeli mekanan jadi; (3) membuat hadia dan kartu-kartu ucapan sendiri dirumah dari pada membeli; (4) memperbaiki pakaian, mainan, peralatan, dan alat-alat dapur dari pada membeli baru; (5) menyewa daripada membeli jika memungkinkan.

2. Menggunakan kembali 
Menggunakan kembali dapat ditempu dengan cara: (1) menggunakan kembali botol-botol plastik atau botol-botol gelas yang sebelumnya dianggap tidak memiliki manfaat tau tidak berguna sehingga menjadi berguna kembali; (2) jika mempunyai banyak barang yang sudah tidak digunakan lagi maka bisa dimanfaatkan kembali; (3) memberikan kepada orang lain untuk menggunakan kembali; (4) menggunakan kembali kertas-kertas yang telah digunakan pada satu sisinya untuk dipergunakan kembali, misalnya kertas gambar bagi anak, draf surat, lembar observasi, lembar belajar bagi anak, daftar belanja, pesan-pesan telepon, permainan anak, koran bekas dan lain-lain. (5) berhati-hatilah dalam membuka amplop karena dengan berhati-hati amplop tersebut dapat digunakan kembali; dan (6) gunakan kembali tas-tas plastik dan simpanlah untuk digunakan kembali pada lain waktu untuk keperluan tertentu.

\section{Menggantikan}

Gantilah pembungkus barang atau makanan dengan pembungkus yang dapat digunakan kembali, agar mudah didaur ulang, atau dikomposkan, dan dipisahkan pada saat sampah akan dimasukan pada tempat pembuangan sampah.

\section{Memisahkan}

Memisahkan berarti memisahkan sampah rumah tangga antara sampah basa dan sampa kering. Sampah basah adalah sampah yang mudah membusuk seperti sisa makanan, sayuran, buah-buahan, dan daunan dari sapuan halaman rumah, sampah rumah tangga lain yang sejenis. Sampah kering adalah sampah yang tidak mudah membusuk seperti kertas, plastik, logam, gelas, karet, baterai, dan sampah rumah tangga lain. 
Manfaat pemisahan sampah rumah tangga yaitu: (1) memudahkan dalam pengelolaan sampah; (2) mengurangi jumlah sampah yang diangkut ke TPA; dan (3) menambah persentase sampah kering yang dapat didaur ulang dan sampah basah yang dapat dikomposkan serta mempercepat proses menuju daur ulang dan pengomposan. Cara praktis pemisahan sampah rumah tangga adalah; (1) menyediakan dua tempat sampah, satu untuk sampah basah dan yang lain untuk sampah kering; (2) memisahkan antara sampah basah dan sampah kering saat memasak serta pada kegiatan sehari-hari; dan (3) sampah basah dimasukan kedalam tempat sampah basa dan sampah kering dimasukan kedalam tempat sampah kering.

5. Mendaur ulang

Dengan memisahkan antara sampah basah dan sampah kering berarti memperlancar proses daur ulang sampah kota, karena sampah yang akan didaur ulang tidak tercampur aduk dengan sampah lainnya. Daur ulang sampah meliputi daur ulang sampah kertas, sampah plastik, sampah kaleng, dan sampah gelas.

\section{Mengomposkan}

Pengomposan sampah rumah tangga dapat dilakukan bersamaan dengan pemendaman sampah basah. Sampah basah dimasukan kedalam lubang yang telah sediakan, dapat dicampur dengan sedikit tanah, dan diberi cacing tanah untuk mempercepat proses penguraian. Pengomposan sampah rumah tangga ini dapat diterapkan disetiap rumah tangga dan dapat dilakukan oleh semua anggota keluarga, ibu, ayah, anak. pembantu rumah tangga ataupun tukang kebun. 


\section{F. Kegiatan Pengelolaan Sampah}

Pengelolaan sampah ialah kegiatan yang sistimatis, menyeluruh dan berkesinambungan yang meliputi pengurangan dan penanganan sampah. Kegiatan pengelolaan sampah menurut UU No 18 tahun 2008 ialah sebagai berikut:

a. Pengurangan sampah

Pengurangan sampah dilakukan dengan cara mengurangi produksi dan komsumsi barang yang kemasannya menggunakan bahan yang tidak dapat/ sulit untuk didaur ulang.

b. Pemilahan sampah

Pemilahan sampah dilakukan dengan cara sebagai berikut.

1) Memisahkan sampah yang mengandung bahan berbahaya dan beracun dan tidak mengandung bahan berbahaya dan beracun.

2) Memisahkan sampah yang tidak mengandung bahan berbahaya dan beracun menjadi sampah kering dan sampah basah.

c. Pengumpulan sampah

Pengumpulan sampah dilakukan dengan memindahkan sampah dari sumber sampah ketempat penyimpanan sementara.

d. Pemanfaatan sampah

Sampah dapat dimanfaatkan baik untuk kepentingan komersial maupun non komersial.

e. Pengangkutan sampah

Pengangkutan sampah dari tempat penyimpanan sementara ke TPA, diangkut dengan alat angkut khusus yang disertai dengan dukumen sampah. 
f. Pengolahan sampah

Pengolahan sampah dapat dilakukan dengan cara penimbunan (sanitary landfill), insenerasi dan / atau cara lainnya sesuai dengan kebutuhan.

\section{G. Paragdigma Baru (transformative) Pemahaman Mengenai Sampah}

Sejalan dengan upaya-upaya demokrasi, desentralisasi, dan pemberdayaan dalam pembangunan Indonesia, maka koreksi-koreksi mendasar sangat diperlukan dalam melihat dan memahami persoalan sampah. Koreksi terhadap pemahaman sampah dimaksud haruslah bersifat transpormative yakni memunculkan adanya pemahaman-pemahaman dan gagasan-gagasan segar dan inovatif yang menguak sisi-sisi positif dan keberadaan sampah yang mencerminkan ide-ide demokrasi, desentralisasi dan pemberdayaan tersebut. Menurut Skripsianti (2008), perubahan paradigma baru tersebut menyangkut: pertama pemahaman sampah sebagai barang buagan yang tidak berguna dan tidak bernilai ekonomis selayaknya ditinggalkan, sebab hal itu juga tidak didukung oleh fakta-fakta empirik yang menunjukan bahwa sampah ternyata dapat menjadi lahan bisnis yang menguntungkan dan mampu memberikan kesempatan kerja, khususnya kepada orang-orang yang tidak masuk dipasar kerja formal dan informal lainya. Sampah selayaknya dilihat sebagai sumberdaya dan bahan baku yang mempunyai nilai guna dan ekonomis. Sisi positif keberadaan sampah selayaknya menjadi rangsangan (stimulator) kuat bagi perencana daerah dan tata ruang wilayah untuk meningkatkan kualitas perencanaannya, khususnya dalam rangka peningkatan aktivitas perekonomian daerah/kota serta keserasian, keselarasan dalam penataan dan fungsi-fungsi kota dan wilayah dengan memperhitungkan keberadaan fungsifungsi pengelolaan sampah kedalam konsep, kebijakan, dan program-program 
pembangunan daerah dan penataan ruang, baik dilihat dari aspek sosial, ekonomi, lingkungan hidup, maupun tata ruang wilayah.

Kedua, implikasi dari pemahaman itu akan melahirkan pemahaman baru berikutnya, yakni ditingkat masyarakat dan pemerintah, bahwa urusan sampah menjadi urusan bersama, dikelolah secara bersama-sama dan menjadi bagian etika sosial yang internalisasi dan sosialisasinya dilakukan dengan massif baik diruang formal maupun non formal. Pada giliranya, sampah menjadi urusan yang memerlukan perhatian serius dari semua pihak, seperti halnya keseriusan dalam menangani urusan pangan. Urusan sampah bukan bukan lagi sekedar urusan mengumpulkan, memindahkan, mengangkut, membuang, memusnakan, melainkan urusan mengelola menjadi barang yang mempunyai nilai guna dan ekonomis. Perlakuan yang konvensional berupa penimbunan, pemusnahan dan sebagainya, baru dilakukan terhadap sisa-sisa sampah yang sudah tidak dapat dikelola sama sekali. Selain itu untuk keamanan dan perlindungan terhadap lingkungan hidup, maka pembungan secara terbuka (open dumping) tidak diperbolehkan lagi. Itulah sebabnya menjadi sangat strategis dan dibutuhkan adanya perlibatan peran dan tanggung jawab dari seluruh stakehorders terkait melalui proses-proses demokratisasi, desentralisasi, dan pemberdayaan dalam pengelolaan sampah (UU Pengelolaan Sampah, 2008).

\section{H.Pembelajaran Berbasis Proyek Pada Mata Pelajaran Biologi}

Pembelajaran Berbasis Proyek merupakan pembelajaran yang menggunakan masalah sebagai langka awal dalam mengumpulkan data dan mengintegrasikan pengetahuan baru berdasarkan pengalamannya dalam beraktivitas secara nyata. Pembelajaran berbasis proyek dirancang untuk digunakan pada permasalahan 
komplek yang diperlukan pembelajar dalam melakukan investigasi dan memahaminya.

Pembelajaran Berbasis Proyek adalah pembelajaran dengan menggunakan proyek sebagai metode pembelajaran. Para pelajar bekerja secara nyata, seolaholah ada didunia nyata yang dapat menghasilkan produk secara realistis. Prinsip yang mendasari adalah bahwa dengan aktivitas komplek ini, kebanyakan proses pembelajaran yang terjadi tidak tersusun dengan baik. Selain itu Pembelajaran Berbasis Proyek merupakan suatu pembelajaran yang di desain untuk persoalan yang kompleks dimana siswa melakukan investigasi untuk memahaminya, menekankan pembelajaran dengan aktivitas yang lama, tugas yang diberikan pada siswa bersifat multidisiplin,dan berorentasi pada produk (artifak).

Pembelajaran berbasis proyek adalah salah satu pembelajaran yang berlandaskan teori konstruktivisme. Dengan demikian ciri-ciri konstruktivisme juga melekat pada pembelajaran berbasis proyek. Menurut Blumenfield $d k k$. dalam Mahanal, 2009) mendiskripsikan pembelajaran berbasis proyek sebagai pembelajaran yang berpusat pada proses relatif berjangka waktu, berfokus pada masalah, pembelajaran bermakna dengan mengintegrasikan konsep-konsep dari sejumlah pengetahuan, disiplin atau bidang studi. CORD dalam Mahanal, 2009) Pembelajaran berbasis proyek dikonsepsikan sebagai pembelajaran yang menekankan pada waktu yang lama, penugasan multidisiplin dan aktivitas yang berpusat pada siswa serta berfokus pada persoalan atau masalah kehidupan nyata. Guru berperan sebagai fasilitator dan menugasi siswa bertujuan untuk dipecahkan oleh kelompok pebelajar. 
Menurut CORD (2007 dalam Mahanal, 2009) menyatakan pembelajaran yang berbasis konstruktivistik bermaksud membawa siswa belajar lebih dalam, menggunakan inkuiri, mengajukan pertanyaan tentang berbagai masalah yang terkait dalam kehidupan siswa. Selanjutnya dikemumakan bahwa pembelajaran berbasis proyek dirancang untuk mengkaji masalah yang komplek dengan mendorong siswa untuk melakukan investigasi secara kolaboratif dalam memahami dan memecahkan berbagai persoalan yang relevan dengan lingkungan siswa. Menurut SSME (2006 dalam Mahanal, 2009) dalam menyelesaikan masalah yang komplek melalui pembelajaran berbasis proyek siswa melakukan hal-hal berikut: (1) bertanya dan menjawab pertanyaan, (2) berargumen, (3) membuat prediksi, (4) mendesain rencana dan/atau eksperimen, (5) mengumpulkan data dan analisis data, (6) membuat kesimpulan, (7) mengkomunikasikan ide dan penemuannya, (8) membuat pertanyaan baru, dan (9) membuat artifak.

Menurut beberapa difinisi yang dikemukan oleh para ahli, disarikan oleh Thomas (2000 dalam Mahanal, 2009) bahwa proyek dalam pembelajaran berbasis proyek merupakan tugas komplek, yang didasarkan pada pertanyaan-pertanyaan yang menantang atau permasalahan, yang melibatkan para siswa di dalam desain, pemecahan masalah, pengambilan keputusan, atau aktivitas investigasi: memberi peluang para siswa untuk bekerja secara otonomi dengan periode waktu yang lama; dan akhirnya menghasilkan produk-produk yang nyata atau presentasipresentasi. Keanekaragaman penjelasan tentang pembelajaran berbasis proyek (PBP) menggambarkan tidak adanya suatu model yang bersifat universal menerima teori dari pembelajaran berbasis proyek, sehingga menimbulkan suatu variasi yang besar dari riset pembelajaran berbasis proyek dan aktivitas 
pengembanganya. Variasi ini menimbulkan kesulitan untuk menentukan antara proyek memenuhi kriteria pembelajaran berbasis proyek (PBP).

Tinjauan ulang dari riset mengungkapkan bahwa ada satu tradisi lonstanding disekolah-sekolah yang melakukan proyek, hands-on activities, melibatkan para siswa didalam lingkungan-lingkungan yang membuat mereka mengembangkan tema-tema interdisipliner. Dalam hal ini, pembelajaran berbasis proyek pada dasarnya berbeda antara instruksi kelas tradisional dan Discoveri Learning. Thomas (2000 dalam Mahanal, 2009) menandai 5 kriteria pembelajaran berbasis proyek, yaitu centrality, berfokus pada pertanyaan yang autentik, penyelidikan-penyelidikan bersifat konstruktivis, otonomi pebelajar, dan realisme.

Centrality, bahwa pembelajaran berbasis proyek adalah pusat atau inti kurikulum, bukan pelengkap kurikulum. Proyek dalam pembelajaran berbasis proyek adalah strategi pembelajaran, artinya siswa mengalami dan belajar konsepkonsep esensial suatu disiplin ilmu melalui proyek. Sedangkan kegiatan proyek yang bertujuan untuk pengayaan materi diluar kurikulum tidak termasuk pembelajaran berbasis proyek. Hal ini dapat dilihat pada suatu proyek yang mengikuti langkah-langkah instruksi tradisional dengan menyediakan ilustrasiilustrasi, contoh-contoh, praktik-praktik tambahan, penggunaan dari bahan-bahan menurut aplikasi-aplikasi.

Pembelajaran berbasis proyek berfokus kepada pertanyaan-pertanyaan autentik yang membuat para siswa berjuang keras untuk mengatasi tugas yang diberikan dan menghubungkan kinerja-kinerja mereka kepada konsep-konsep inti dan prinsip-prinsip. Menurut kriteria pembelajaran berbasis proyek para siswa harus pandai membuat suatu koneksi antara aktivitas dengan pengetahuan 
konseptual yang mendasarinya dan diharapkan membantu untuk berkembang Baron et al.,(1998 dalam Mahanal, 2009).

\section{Langkah- Langkah Project Based Learning Pada Mata Pelajaran Biologi}

Implementasi pembelajaran berbasis proyek secara umum memiliki tiga pedoman langkah: Planning (perencanaan), Creating (mencipta atau implementasi), dan Processing (pengolahan), seperti tertera pada Gambar 1.1.

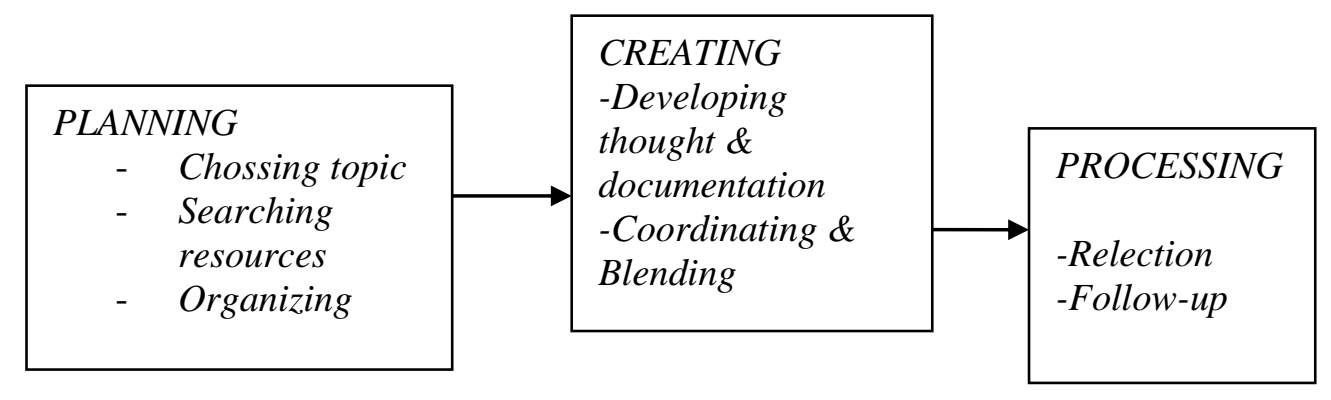

\section{Gambar 1.1 Kerangka Umum Pembelajaran Berbasis Proyek (Sumber: Mahanal, 2009: 39)}

\section{a. Planning}

Pada tahapan ini kegiatan yang dilakukan adalah a) merancang seluruh proyek, kegiatan dalam langka ini adalah: mempersiapkan proyek, secara lebih rinci mencakup: pemberian informasi tujuan pembelajaran, guru menyampaikan fenomena nyata sebagai sumber masalah, pemotivasian dalam memunculkan masalah dan pembuatan proposal, b) mengorganisir pekerjaan, kegiatan dalam langkah ini adalah: merencanakan proyek, secara lebih rinci mencakup: mengorganisir kerjasama, memilih topik, memilih informasi terkait proyek, membuat prediksi, dan membuat deasin investigasi. 


\section{b. Creating,}

Dalam tahapan ini siswa mengembangkan gagasan-gagasan proyek, mengkombinasikan ide yang muncul dalam kelompok, dan membangun proyek. Tahapan kedua ini termasuk aktifitas pengembangan dan dokumentasi. Pada tahapan ini pula siswa menghasilkan produk (artefak) yang nantinya akan dipresentasikan dalam kelas.

\section{c. Processing}

Tahapan ini meliputi presentasi proyek dan evaluasi. Pada presentasi proyek akan terjadi komunikasi secara aktual kreasi ataupun temuan dari investigasi kelompok, sedangkan pada tahapan evaluasi akan dilakukan refleksi terhadap hasil proyek, analisis dan evaluasi dari proses-proses belajar.

Schola-21 (2008 dalam Mahanal, 2009) mengusulkan 5 tahap pembelajaran pembelajaran berbasis proyek sebagai berikut.

a) Persiapan Proyek

Proyek dimulai dengan pembentukan tim yang kuat. Setiap anggota saling mempelajari satu dengan yang lainnya tentang kemampuan setiap individu, mereka saling berbagi untuk keberhasilan proyek. Selanjutnya, untuk memudahkan Cooperative Learning diperlukan atmosfer belajar yang baik, mereka menentukan aturan dan tujuan sebagai pedoman kolaborasi mereka.

b) Perencanaan Proyek

Siswa dihadapkan pada masalah biologi yang riil dilapangan dan mendorong siswa mengidentifikasi masalah tersebut. Pada tahap ini siswa dibimbing menemukan masalah dalam konteks dunia nyata, misalnya siswa diminta mempelajari tentang proses daur ulang sampah, siswa secara kooperatif 
menganalisis masalah, tujuan, waktu yang disediakan, lokasi proyek, dll. Bila proyek ini komplek pembagian kerja dalam kelompok akan dibentuk. Siswa dilatih belajar bermufakat, belajar mendifinisikan tujuan secara individu dan melakukan eksplorasi untuk keberhasilan belajar. Guru sebagai fasilitator membimbing siswa melakukan perencanaan proyek. Kelompok kerja dibimbing "merencanakan artifak yang akan dibagun" (analisis kebutuhan serta langkahlangkah dalam proyek).

c) Imflementasi Proyek

Pada tahap ini realisasi proyek siap dimulai, kelompok kerja mengerjakan item-item sesuai dengan perencanaan dan waktu yang telah ditentukan. Terdapat beragam instrumen untuk membantu mancari jawaban terkait dengan masalah daur ulang sampah. Guru membimbing siswa untuk melakukan pengujian produk (analisis data) serta menyusun artifak misalnya berupa laporan hasil penelitian.

d) Presentasi Proyek

Guru membimbing siswa menyiapkan presentasi antara kelompok yang satu dengan kelompok yang lainya atau untuk audiens yang luas. Presentasi ini dimaksudkan untuk mengkomunikasikan secara aktual kreasi atau temuan dari investigasi yang dilakuakn oleh kelompok.Presentasi proyek disampaikan didepan kelas atau mungkin dalam bentuk pameran yang diadakan dilingkungan sekolah atau tempat lain.

e) Evaluasi Proyek

Penilaian proses dan hasil adalah dua aspek penilaian yang popular dalam pembelajaran berbasis proyek. Penilaian proses dan hasil proyek dapat menggunakan cara anecdotal record, cheklis observasi atau fortofolio. 
Kesepakatan-kesepakatan belajar dan kelompok kerja kolaborasi perlu

didiskusikan. Berdasarkan uraian tentang fase pembelajaran berbasis proyek

diatas, disusun sintaks pembelajaran berbasis proyek tertera pada Tabel 2.1

Tabel 2.1 Langkah-Langkah Pokok dan Sintak Pembelajaran Berbasis Proyek

\begin{tabular}{l}
\hline Langkah-langkah pokok (Sintak $P j B L$ ) \\
\hline Planing \\
1. Menayangkan DVD 6M \\
2. Merancang seluruh proyek \\
\\
- Mengorganisir kerja \\
sama/kolaborasi \\
• Memilih topik \\
Memilih sumber \\
daya/informasi yang terkait \\
- Membuat desain investigasi
\end{tabular}

Creating

Bekerjasama /dengan yang lain

1. Meneliti Data

- Bekerjasama dengan mengumpulkan data

- Menganalisis data

2. Mengembangkan pemikiran \& dokumentasi

- Kerjasama dalam membuat visualisasi artefak-artefak (menyusun laporan proyek) dengan membangun gagasan-

\section{Processing} gagasan

1. Presentasi laporan proyek atau artfak siswa mengkomunikasikan secara actual kreasi atau temuan dari investigasi kelompok

2. Refleksi dan tindak lanjut, evaluasi

- Refleksi dan evaluasi terhadap hasil proyek

- Analisis dan evaluasi prosesproses belajar
1. Persiapan Proyek Kegiatan PBM

- Guru menginformasikan tujuan pembelajaran

- Guru menginformasikan fenomena nyata sebagai sumber masalah

- Siswa menyusun jadwal proyek

- Siswa membuat dan menyepakati atauran kolaborasi didalam keseluruhan aktivitas proyek

2. Perencanaan proyek; siswa melakukan.

- Membentuk kelompok

- Mengidentifikasi tema dan pemilihan proyek (tema)

- menelusuri sumber

- Merumuskan masalah sesuai tema

- Menyusun hipotesis

- Menentukan variabel penyusunan instrument dan prosedur penelitian

3. Pelaksanaan Proyek

Organisasi Kegiatan Belajar Mengajar (KBM); Siswa melakukan:

- Investigasi (mengumpulkan data)

- Analisis data

- Menarik kesimpulan

- Mengkomunikasikan gagasan atau temuan degan anggota kelompok

- Bekerjasama menyiapkan presentasi /menyusun laporan ilmiah hasil investigasi atau membuat artefak lainya.

\section{Presentasi Proyek}

Siswa bekerjasama dalam penyajian laporan proyek (artefak). Presentasi proyek mungkin dalam bentuk pameran yang diadakan dilingkungan sekolah

\section{Tahap Evaluasi}

- Refleksi untuk mengevaluasi proses PBM dengan PBP sebagai acuan tindak lanjut

- Evaluasi proses menggunakan evaluasi diri sendiri, evaluasi teman sebaya, dan portofolio berlangsung selama pembelajaran mulai sampai terakhir 


\section{J. Keuntungan Pembelajaran Berbasis Proyek}

a. Meningkatkan motivasi. Laporan-laporan tentang pembelajaran berbasis proyek banyak yang mengatakan bahwa siswa menjadi tekun sampai melewati batas waktu pembelajaran dikelas dan berusaha keras dalam menyelesaikan proyeknya guru juga melaporkan pengembangan dalam kehadiran dan berkurangnya keterlambatan siswa dalam melaporkan bahwa belajar dalam proyek lebih santai dari pada komponen kurikulum lainya.

b. Meningkatkan kemampuan pemecahan masalah. Penelitian pada pengembangan keterampilan kognitif tigkat siswa menekankan perlunya bagi siswa untuk terlibat didalam tugas-tugas pemecahan masalah dan perlunya untuk pembelajaran khusus dalam menemukan dan memecahkan masalah. Lingkungan belajar pada pembelajaran berbasis proyek membuat siswa menjadi lebih aktif dan berhasil memecahkan problem-problem yang komplek.

c. Meningkatkan kolaborasi. Pentingnya kerja kelompok dalam proyek memerlukan siswa mengembangkan dan memperaktikan keterampilan komunikasi (Johnson \& Johnson, 2000). Kelompok kerja kooperatif, evaluasi siswa, pertukaran informasi online adalah aspek-aspek kolaboratif dari sebuah proyek. Teori-teori kognitif yang menegaskan bahwa belajar adalah Fenomena sosial, bahwa siswa akan belajar lebih baik didalam lingkungan secara kolaboratif (Vygotsky, 1978).

d. Meningkatkan keterampilan mengelola sumber, bagian dari siswa yang Independen yaitu bertanggung jawab untuk menyelesaikan tugas yang komplek. pembelajaran berbasis proyek yang mengiplementasikan secara baik memberikan kepada siswa pembelajaran dan praktik mengorganisasikan 
proyek, dan membuat alokasi waktu dan sumber-sumber lain seperti perlengkapan untuk menyelesaikan tugas.

\section{K. Kemampuan Berpikir Kritis}

Soemarjono (1992 dalam Hotima, 2011) berpikir kritis adalah mewujudkan suatu gagasan untuk mencapai tujuan, berpikir adalah suatu proses untuk mengatur informasi yang tersedia dalam mencapai suatu permasalahan berpikir kritis menagatur informasi (Intelegensi) untuk memperoleh suatu jawaban atas suatu masalah. Handayanto (2003: 94) menyatakan bahwa kebiasaan berpikir kritis ilmiah siswa adalah para siswa harus terlibat secara actif dalam mengajukan hipotesis, mengumpulkan dan menggunkan bukti, merancang penyelidikan dan proses-proses serta mengutamakan keingintahuan dan kreatifitas siswa. Kebiasaan pemikiran yang dimaksud adalah pemecahan masalah. Salah satu bentuk pemecahan masalah adalah pada proyek sain yang dilakukan dalam penyelidikan kelompok.

Kemampuan berpikir kritis adalah suatu kegiatan mental berupa pelukisan gagasan berdasarkan pengetahuan yang ada dengan memperhitungkan hubungan sebab akibat yang dirangkaikan secara logis dan rasional. Berpikir bertujuan untuk memecahkan masalah, menemukan hubungan suatu hal dengan hal lainnya dan menemukan sangkut paut hubungan satau hal degan hal lainya. (Muslihati dalam Budiarti, 2007).

\section{Pengetahuan Belajar Biologi Melalui Pembelajaran Berbasis Proyek}

Tujuan belajar adalah ingin mendapatkan pengetahuan, keterampilan dan penanaman sikap mental atau nilai-nilai. Pencapain tujuan belajar berarti akan 
mengahasilkan hasil belajar. Sudah menjadi kewajiban siswa untuk belajar dan terus belajar sepanjang hidupnya. Menurut Gagne dalam Dimyati (2006) belajar merupakan kegiatan yang komplek, hasil belajar berupa kapabilitas setelah belajar orang memiliki keterampilan, pengetahuan, sikap dan nilai. Timbulnya kapabilitas tersebut adalah stimulus yang berasal dari lingkungan dan proses kognitif yang dilakukan oleh pembelajar. Dengan demikian belajar adalah seperangkat proses kognitif yang mengubah sifat stimulus lingkungan melewati pengolahan informasi menjadi kapabilitas baru. Dalam penelitian ini yang menjadi indikator pengetahuan yaitu mengacu kepada ranah kognitif menurut Bloom yaitu.

1. Pengetahuan atau knowledge $(\mathrm{C} 1)$

Pengetahuan mencakup kemampuan mengenali, mengetahui, dan mengingat hal-hal yang telah dipelajari dan tersimpan dalam ingatan.Pengetahuan berkenaan dengan fakta atau istilah-istilah, peristiwa, pengertian, kaidah, teori, dan metode.

2. Pemahaman atau comprehension (C2)

Pemahaman mencakup kemampuan untuk menyerap pengertian dari hal-hal yang telah dipelajari. Pada jenjang ini siswa dituntut untuk mengerti dan memahami konsep yang dipelajari. Kemampuan memahami terdiri atas kemampuan menterjemahkan, menginterpretasikan, dan mengeksplorasi.

\section{Penerapan atau aplication (C3)}

Penerapan merupakan kemampuan menerapkan pengetahuan yang telah diperoleh dalam kegiatan pembelajaran untuk menghadapi situasi baru yang ada dalam kehidupan sehari-hari. 
4. Analisis atau analysis (C4)

Analisis merupakan upaya memisahkan suatu kesatuan menjadi unsur-unsur bagian, sehingga jelas hirarkinya/eksplisit unsur-unsurnya meliputi unsur analisis hubungan dan analisis prinsip yang terorganisasi

5. Sintesis atau syntesis (C5)

Sintesis adalah kemampuan menyatukan unsur-unsur menjadi satu kesatuan yang menyeluruh. Sintesis selalu menyatukan unsur baru, sehingga menyatukan unsur-unsur dari hasil analisis tidak dapat disebut sintesis.

6. Evaluasi atau evaluation (C6)

Evaluasi merupakan kemampuan memberi keputusan tentang skor tertentu yang ditetapkan dengan sudut pandang tertentu, misalnya sudut pandang tujuan, metode, dan materi. Alat ukur yang digunakan untuk tes pengetahuan adalah dengan teknik tes bentuk uraian.

\section{Sikap Siswa Melalui Pembelajaran Berbasis Proyek}

Sikap adalah predisposisi atau kecendrungan yang dipelajari seseorang individu untuk merespon secara positif atau negatif dengan intensitas yang moderat atau memadai terhadap obyek, situasi, konsep atau orang lain (Aiken dalam Darmawan 2009). Sikap ini akan memberi arah kepada pembuatan atau tindakan seseorang, karena sikap atau "etitude”merupakan kecendrungan untuk bertindak (tendency of behave). Sedangkan menurut White (1998 dalam Darmawan 2009) wilayah etitude mencakup juga wilayah kognitif. Gerungan (2000 dalam Darmawan, 2009) menjelaskan bahwa sikap dapat dipahami: 1) sikap ditumbuhkan dan dipelajari sepanjang perkembangan orang yang bersangkutan dalam keterkaitannya dengan obyek tertentu, 2) sikap merupakan hasil belajar 
manusia, sehingga dapat ditumbuhkan dan dikembangkan melalui proses belajar, 3) sikap selalu berhubungan dengan obyek sehingga tidak berdiri sendiri, 4) sikap berhubungan dengan satu obyek sejenis, 5) sikap memiliki hubungan dengan aspek motivasi dan perasaan atau emosi.

Menurut Azwar (2007 dalam Darmawan, 2009) bahwa sikap terbentuk dari interaksi antara komponen kognitif, afektif, dan konatif, hal tersebut menunjukkan bahwa sikap merupakan hasil belajar sehingga dapat dipengaruhi atau dikembangkan menurut prinsip-prinsip belajar tertentu. Dalam pembelajaran berbasis proyek siswa terbagi dalam kelompok, hal ini akan mampu meningkatkan dan menambah nilai sosial antar siswa. Dengan pengalaman langsung yakni melakukan penelitian dan melihat kondisi lingkungan yang nyata diharapakan akan mampu menambah wawasan siswa.

\section{N. Keterampilan Dalam Pengelolaan Sampah}

Keterampilan siswa dalam pengelolaan sampah yaitu meliputi tentang pembudayaan 6M yaitu keterampilan mengurangi sampah, keterampilan menggunakan kembali sampah, keterampilan mengganti, keterampilan memisahkan sampah, keterampilan mendaur ulang sampah, keterampilan mengomposkan sampah. Tes keterampilan pengelolaan sampah dapat diukur dengan mengunakan tes keterampilan dan penilaian produk.

\section{O. Kerangka Berpikir}

Rendahnya pengetahuan siswa tentang pentingnya pengelolaan sampah di SMA Negeri Sumbawa Besar disebabkan oleh belum meratanya kurikulum yang memasukan program pengelolaan sampah melalui mata pelajaran di sekolah 
sehingga menyebabkan siswa kurang perhatian terhadap persoalan sampah. Hal ini juga disebabkan karena masih dari separuh kota/kabupaten di Indonesia yang memasukan masalah sampah pada kurikulum sekolah baik monolitik maupun terintegrasi dengan mata pelajaran lain. Melalui penelitian ini Salah satu cara untuk menanamkan sikap siswa agar paham tentang pentingnya pengelolaan sampah yaitu strategi pembelajaran berbasis proyek berbantuan media $D V D$ 6M untuk melihat pengaruhnya terhadap kemampuan berpikir kritis, pengetahuan, sikap, dan keterampilan siswa dalam pengelolaan lingkungan.

Penggunaan media DVD 6M bertujuan untuk membantu siswa dalam memahami cara-cara pengelolaan sampah, dalam DVD 6M dijelaskan tentang konsep 6M yaitu suatu upaya pengelolaan sampah rumah tangga, yang terdiri atas: (1) mengurangi, berarti suatu upaya mengurangi jumlah sampah yang kita timbulkan; (2) menggunakan kembali, berarti memakai atau memanfaatkan kembali sampah rumah tangga; (3) mengganti, berarti mengganti jenis bahan kebutuhan rumah tangga terutama dengan jenis bahan yang lain; (4) memisahkan, berarti memisahkan sampah rumah tangga antara sampah basah dan sampah kering yang sejenis; (5) mendaur ulang, berarti memanfaatkan kembali sampah rumah tangga dengan mengolahnya terlebih dahulu; dan (6) mengomposkan, berarti suatu upaya mengolah sampah rumah tangga menjadi kompos.

Landasan dari pembelajaran berbasis proyek adalah kontekstual, inkuiri, kooperatif. Pendekatan kontekstual merupakan pendekatan yang memungkinkan siswa untuk menguatkan, memperluas dan menerapkan pengetahuan dan keterampilan akademiknya dalam berbagai tatanan kehidupan baik disekolah maupun diluar sekolah. Pembelajaran kontekstual berpotensi mengembangkan 
ranah pengetahuan, kemampuan berpikir kritis, sikap serta aktivitas siswa dalam menyelesaikan masalah sehari-hari. Pembelajaran dengan penemuan (Inkuiri) akan mendorong siswa untuk terlibat aktif dengan konsep dari prinsip mereka sendiri, dan guru mendorong siswa untuk memiliki pengalaman dan melakukan percobaan yang memungkinkan mereka menemukan prinsip-prinsip untuk diri mereka sendiri, dengan inkuiri siswa akan mampu mengkonstruksi pemahaman lingkungan serta faktor yang mempengaruhi pencemaran lingkungan. Pembelajaran kooperatif akan mampu membuat siswa bekerja dengan kelompok, melalui komunikasi sosial, menyampaikan ide dan gagasan, serta tanggung jawab konstribusi mandiri dalam kelompok.

Dari paparan diatas penerapan strategi pembelajaran berbasis proyek berbantuan $D V D$ 6M yang digunakan dalam proses pembelajaran biologi akan mampu meningkatkan kemampuan berpikir kritis, pengetahuan, sikap,dan keterampilan siswa dalam pengelolaan sampah. Peningkatan kemampuan berpikir kritis, pengetahuan, sikap dan keterampilan siswa dalam pengelolaan lingkungan dapat dilihat dari hasil tes pengetahuan, sikap, dan keterampilan siswa dalam pengelolaan sampah. 
Berdasarkan penjelasan yang telah dipaparkan diatas, dapat dibuat ke rangka berpikir yang mengarah pada pemecahan masalah penelitian.

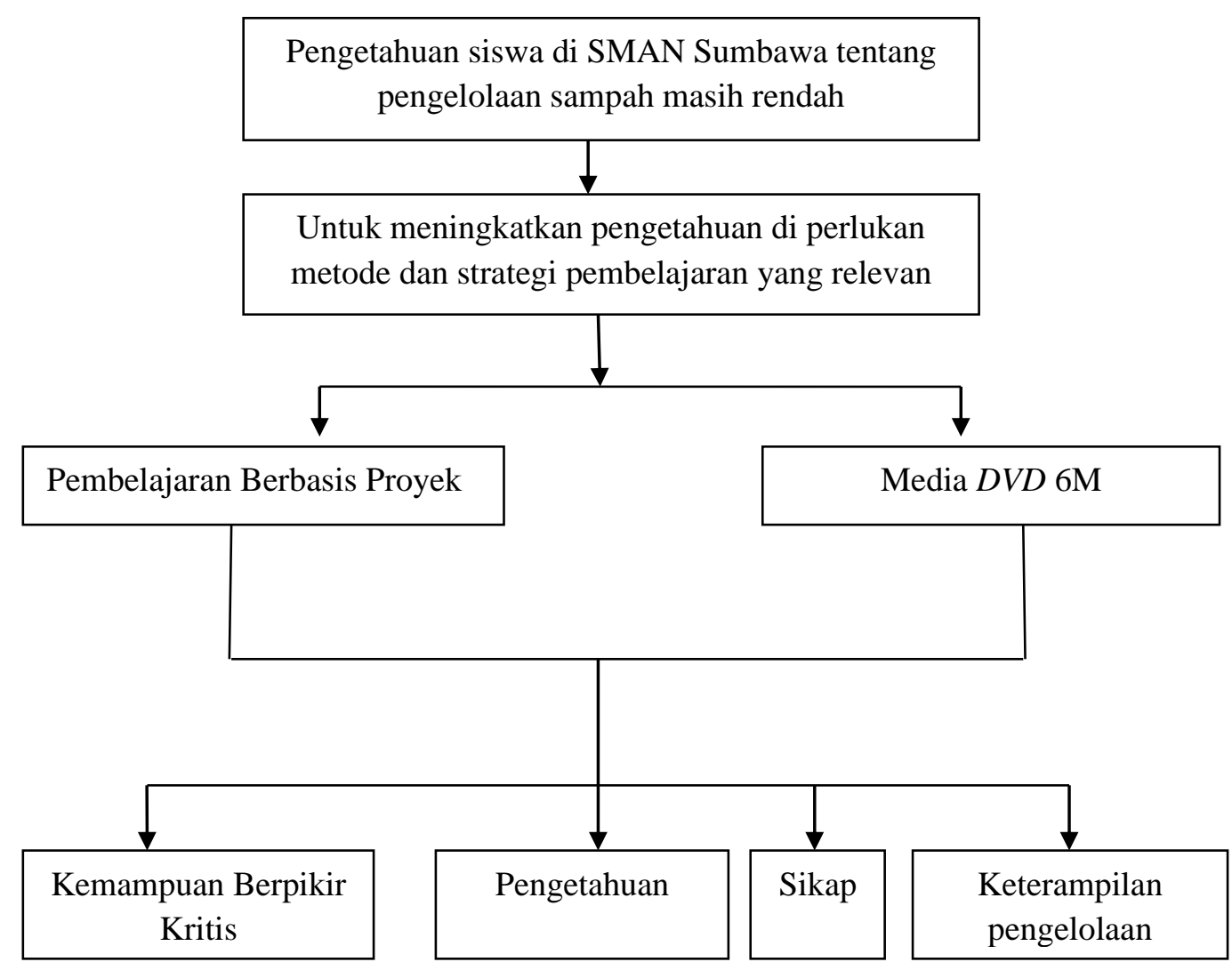

Gambar 2.1 Kerangka Berpikir Pengaruh Strategi Pembelajaran Berbasis Proyek Berbantuan Media DVD 6M Terhadap Kemampuan Berpikir Kritis, Pengetahuan, Sikap,dan Keterampilan Siswa dalam Pengelolaan lingkungan. 


\section{BAB III}

\section{METODE PENELITIAN}

\section{A. Rancangan Penelitian}

Penelitian ini menggunakan teknik eksperimen semu disamping itu juga menggunakan teknik penelitian deskriptip. Rancangan penelitian yang dipilih adalah Pretest-Posttest Control Group Design (Arikunto, 2006). Penelitian ini bertujuan untuk memperoleh gambaran secara nyata mengenai pengaruh strategi pembelajaran berbasis proyek berbantuan media $D V D 6 M$ terhadap kemampuan berpikir kritis, pengetahuan, sikap, dan keterampilan siswa dalam pengelolaan sampah di SMAN Sumbawa Besar.

Penelitian ini menggunakan dua kelompok siswa yang terdiri atas kelompok kelas eksperimen dan kelas kontrol. Untuk kelas eksperimen diberi perlakuan dengan perangkat pembelajaran berbasis proyek dengan berbantuan DVD 6M. Sedangkan kelompok kelas kontrol yaitu kelompok belajar yang belajarnya secara konvensional atau tidak diberikan perlakuan.

\section{Tabel 3.1 Desain Penelitian}

\begin{tabular}{cccc}
\hline Kelompok & Pretes & Perlakuan & Postes \\
\hline A & Y1 & X1 & Y2 \\
\hline B & Y3 & X2 & Y4
\end{tabular}


Keterangan:

1. $\mathrm{X} 1=$ Penerapan $D V D$ 6M melalui pembelajaran Project Based Learning

2. $\mathrm{X} 2=$ Penerapan pembelajaran konvensional

3. $\mathrm{Y} 1 \& \mathrm{Y} 3=$ Skor tes awal

4. $\mathrm{Y} 2 \& \mathrm{Y} 4=$ Skor tes akhir

5. $\mathrm{A}=$ Kelompok eksperimen

6. $\mathrm{B}=$ Kelompok kontrol

Variabel-variabel yang terlibat dalam penelitian ini adalah sebagai berikut.

1. Variabel bebas, yaitu strategi pembelajaran berbasis proyek berbantuan media DVD 6M.

2. Variabel terikat yaitu kemampuan berpikir kritis, pengetahuan, sikap, dan ke terampilan siswa dalam pengelolaan lingkungan.

\section{B. Populasi dan Sampel}

a. Populasi

Populasi dalam penelitian ini yaitu seluruh siswa kelas X SMA Negeri di Kota Sumbawa Besar, yang terdiri dari 4 sekolah Negeri yaitu: SMA Negeri 1, SMA Negeri 2, SMA Negeri 3, dan SMA Negeri 4.

b. Sampel

Sampel dalam penelitian ini adalah siswa kelas X di SMA Negeri 1, SMA Negeri 3 dan SMA Negeri 4 Sumbawa Besar dengan masing masing dua kelas untuk dijadikan sampel. Untuk rencana sampel yang akan digunakan yaitu pada SMA Negeri 1 kelas $\mathrm{X} 1$ dan $\mathrm{X} 2$ dengan jumlah siswa masing-masing kelas sebanyak 30 orang. Sedangkan pada SMA Negeri 3 yaitu kelas X5 dan X2 dengan jumlah siswa masing-masing kelas 31 orang kemudian SMA Negeri 4 kelas X2 dan X3 jumlah siswa 33 orang masing-masing kelas. Dari sampel ini satu kelas di jadikan kelas eksperimen dan satu kelas sebagai kelas kontrol. Alasan pengambilan sampel di SMA Negeri I, SMAN Negri 3 dan SMAN Negeri 4 
adalah untuk memenuhi refresentatifnya sampel penelitian. Teknik pengambilan sampel dalam penelitian ini mengunakan Purposive Sampling yaitu pengambilan sampel secara penunjukan langsung.

\section{Instrumen Penelitian}

1. Instrumen Variabel Bebas

Instrumen yang digunakan untuk mengukur variabel bebas pada penelitian ini meliputi: (1) silabus, (2) Rencana Pelaksanaan Pembelajaran (RPP) dengan perangkat pembelajaran dari penerapan $D V D$ 6M melalui pembelajaran Project Based Learning pada kelompok eksperimen dan RPP pada kelompok kontrol yang belajar dengan menggunakan pendekatan pembelajaran konvensional, (3) lembar pengamatan keterlaksanaan pembelajaran. Masing-masing instrumen dijabarkan sebagai berikut.

a. Silabus

Silabus adalah rencana pembelajaran pada suatu dan/atau kelompok mata pelajaran/tema tertentu yang mencakup SK, KD, materi pembelajaran, kegiatan pembelajaran, indikator pencapaian kompetensi, penilaian, alokasi waktu, dan sumber belajar. Silabus bermanfaat sebagai pedoman dalam pengembangan pembelajaran lebih lanjut, seperti pembuatan rencana pembelajaran, pengelolaan kegiatan pembelajaran, dan pengembangan sistem penilaian. Silabus merupakan sumber pokok dalam penyusunan rencana pembelajaran, baik rencana pembelajaran untuk satu SK maupun satu KD. Silabus juga bermanfaat sebagai pedoman untuk merencanakan pengelolaan kegiatan pembelajaran, misalnya kegiatan belajar secara klasikal, kelompok kecil, atau pembelajaran secara individual. Demikian pula, silabus sangat bermanfaat untuk mengembangkan 
sistem penilaian. Dalam pelaksanaan pembelajaran berbasis kompetensi sistem penilaian selalu mengacu pada $\mathrm{SK}, \mathrm{KD}$, dan indikator yang semuanya terdapat di dalam silabus.

b. Rencana Pelakasanaan Pembelajaran (RPP)

Berdasarkan PP 19 Tahun 2005 Pasal 20 dinyatakan bahwa Perencanaan proses pembelajaran meliputi silabus dan rencana pelaksanaan pembelajaran yang memuat sekurang-kurangnya tujuan pembelajaran, materi ajar, metode pengajaran, sumber belajar, dan penilaian hasil belajar. Sesuai dengan Permendiknas Nomor 41 Tahun 2007 tentang Standar Proses dijelaskan bahwa RPP dijabarkan dari silabus untuk mengarahkan kegiatan belajar peserta didik dalam upaya mencapai Kompetensi Dasar (KD).

c. Lembar Pengamatan Keterlaksanaan Pembelajaran

Lembar pengamatan digunakan untuk mengukur dan mengumpulkan data keterlaksanaan pembelajaran dengan menggunakan strategi pembelajaran berbasis proyek berbantuan media $D V D$ 6M. Pengamatan ini dilakukan dengan sasaran guru dan siswa untuk melihat kesesuaian proses pembelajaran dengan sintak dan rencana pelaksanaan pembelajaran (RPP). Instrumen dibuat dalam bentuk chek liskert meliputi instrument keterlaksanaan pembelajaran menggunakan strategi pembelajaran berbasis proyek berbantuan media $D V D 6 M$ dengan target observasi guru dan instrumen keterlaksanaan menggunakan strategi pembelajaran berbasis proyek berbantuan media $D V D 6 M$ dengan target observasi siswa.

2. Instrumen Variabel Terikat

Instrumen yang digunakan untuk mengukur variabel terikat pada penelitian ini terdiri atas: tes kemampuan berpikir kritis, tes tulis pengetahuan 
dan tes sikap dengan bantuk tes uraian. Untuk memperoleh hasil tes kemampuan berpikir kritis, tes pengetahaun siswa, dan tes sikap maka diberikan tes awal (pretes) dan tes akhir (postes). Untuk memperoleh informasi tentang variabel terikat ditas. Masing-masing instrumen dijabarkan sebagai berikut.

\section{a. Kemampuan Berpikir Kritis}

Hasil kemampuan berpikir kritis diukur dengan soal kemampuan berpikir kritis disusun berdasarkan indikator meliputi kemampuan berpendapat, kemampuan membandingkan, kemampuan memberikan alasan, kemampuan menyimpulkan, kemampuan mengelompokan,dan kemampuan menganalis.Instrumen kemampuan berpikir kritis dapat lihat di lampiran 3

b. Tes Pengetahuan

Hasil tes pengetahuan siswa diukur dengan menggunakan isntrumen berupa soal-soal tes. Soal ini berupa soal-soal uraian yang terdiri dari 10 item soal. Macam-macam soal disusun berdasarkan indikator C1,C2,C3,C4,C5,C6. Prosedur pengembangan instrument meliputi; (1) menentukan standar kompetensi, (2) menganalisis kompetensi dasar, (3) menyusun kisi-kisi, (4) menyusun tes, (5) menyusun kunci jawaban, (6) uji validitas isi oleh ahli berdasarkan indikator dan (7), uji coba lapangan untuk menentukan validitas butir, reliabilitas, tingkat kesukaran, dan daya pembeda. Kisi-kisi tes pengetahuan dapat dilihat pada lempiran 4

Validitas butir soal dapat dihitung dengan perhitungan korelasi dengan rumus sebagai berikut. Korelasi Product Moment dari Pearson. Rumus yang digunakan adalah. 


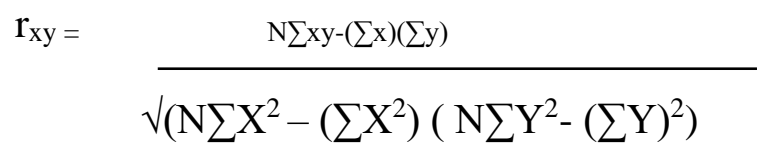

Keterangan:

$\mathrm{R}_{\mathrm{xy}}=$ Koefesien korelasi antara variabel $\mathrm{x}$ dan $\mathrm{y}$

$\mathrm{N}$ = Jumlah sampel

Interpretasi harga menurut $\mathbf{r}_{\mathrm{xy}}$ Arikunto (2006 ) sebagai berikut: 0,81-1,00 sangat tinggi : 0,6-0,80 tinggi, 0,41-0,60 cukup; 0,21-0,40 rendah; dan 0,00-0,20 sangat rendah. Untuk menentukan validitas item ditentukan dengan membandingkan $r$ hitung dengan $r_{\text {tabel }}$ dengan taraf signifikansi 5\%. Jika $r$ hitung $>\mathrm{r}_{\text {tabel }}$ maka item dinyatakan valid, sebaliknya jika $\mathrm{r}_{\text {hitung }}<\mathrm{r}_{\text {tabel }}$ maka item dinyatakan tidak valid.

Pengujian reliabilitas tes yang dilakukan adalah pengujian reliabilitas internal (internal consistency) dengan cara memberikan suatu tes kepada sekelompok individu (single trial) yang bertujuan untuk melihat konsistensi antar item dalam tes. Berdasarkan hasil uji coba kemudian dicari reliabilitas tes keseluruhan menggunakan Spearman-Brown dengan teknik belah dua (split half) dengan rumus sebagai berikut.

$$
\mathrm{r}_{11}=\left[\frac{(2 x r 1 / 21 / 2)}{1+\mathrm{r} 1 / 21 / 2}\right]
$$

(Arikunto, 2006)

\section{Keterangan :}

$\mathrm{r}_{11}=$ reliabilitas tes secara keseluruhan

$r_{1 / 21 / 2}=$ korelasi antara skor-skor setiap belahan tes.

Interpretasi harga $r_{11}$ mengikuti ketentuan Arikunto (2006) sebagai berikut: $0,81-1,00$ reliabilitass sangat tinggi; $0,61-0,80$ reliabilitas tinggi; 0,41 - 
0,60 reliabilitas sedang ; 0,21-0,40 reliablitas rendah, dan 0,00-0,20 reliabilitas sangat rendah. Penerimaan atau penolakan reliabilitas instrument dapat dilihat dari besarnya kooefisien reliabilitasnya. Menurut Arikunto (2006) apabila kooefisien reliabilitas lebih besar dari 0,06 maka instrumen penelitian dianggap reliable.

Tingkat kesukaran setiap butir soal dihitung dengan rumus indeks tingkat kesukaran sebagai berikut.

$$
\mathrm{P}=\frac{\mathbf{B}}{\mathbf{J S}}
$$

(Arikunto, 2006)

Keterangan

$\mathrm{P}=$ Indeks kesukaran

$\mathrm{B}=$ Banyaknya siswa yang menjawab soal dengan benar

$\mathrm{JS}=$ Jumlah seluruh siswa peserta tes

Standar untuk menginterpretasikan besarnya nilai $\mathrm{P}$ adalah sebagai berikut: 0,00 sampai dengan 0,30 adalah sukar; 0,31 sampai 0,70 adalah sedang; dan 0,71 sampai 1,00 adalah mudah.

\section{c. Tes Sikap}

Tes sikap dalam penelitian ini adalaha respon siswa atas permasalahan lingkungan sesuai dengan indikator yang terdapat pada silabus yang kesemuanya mencakup kognisi yaitu sikap siswa dalam menerima (A1), menanggapi (A2), menilai (A3). Kemudian Afeksi yaitu sikap siswa dalam menilai (A3), mengornasisasi (A4), dan Konasi yaitu sikap siswa dalam mengorganisasi (A4) dan menjadikan pola hidup (A5). Alat ukur yang digunakan untuk menentukan nilai sikap yaitu melalui teknik tes bentuk uraian dan lembar pengamatan tes sikap. Kisi-kisi tes sikap dapat dilihat pada lampiran 4. 
d. Keterampilan Siswa Dalam Pengelolaan Sampah

Keterampilan siswa dalam pengelolaan sampah yang meliputi keterampilan pembudayaan 6M yaitu keterampilan siswa dalam mengurangi sampah, keterampilan menggunakan kembali sampah, keterampilan menggantikan sampah, keterampilan memisahkan sampah, keterampilan mendaur ulang sampah, dan keterampilan mengomposkan sampah. Keterampilan siswa dalam penelitian ini dapat diukur dengan tes keterampilan dan penilaian laporan proyek.Instrume keterampilan siswa dalam pengelolaan sampah dapat dilihat pada lampiran 5

\section{Pengumpulan Data}

Data penelitian ini berupa data kuantitaif yang berupa nilai kemampuan berpikir kritis, pengetahuan, sikap, dan skor keterampilan siswa dalam pengelolaan sampah. Data hasil kuesioner skala sikap ini dikumpulkan melalui pre test dan pos test yang dilakukan sebelum, ditengah-tengah dan sesudah seluruh materi pada Standar Kompetensi (SK) yang ditentukan. Adapun standar kompetensi yang akan digunakan adalah mengenal hubungan antara komponen ekosistem, perubahan materi dan energi serta peranan manusia dalam keseimbagan ekosistem sedangkan Kompetensi Dasar (KD) yang akan digunakan terdiri atas dua KD yaitu menjelaskan keterkaitan antara kegiatan manusia dengan masalah perusakan/pencemaran lingkungan dan pelestariannya, dan menganalisis jenis limbah dan daur ulang limbah.

Pengumpulan data dalam penelitian ini akan dilakukan peneliti bersama dua observer dengan kualifikasi pendidikan Strata satu (S1). yaitu Iin Gantihar S.Pd dan Wiwin Andriani, S.Pd yang keduanya berprofesi sebagai guru bidang studi biologi di SMA N 1 Sumbawa. Sedangkan observer untuk SMA N 3 yaitu 
Dra. Ratna dan Nuraini, S.Pd yang merupakan guru pada bidang studi biologi di SMA N 3 Sumbawa, SMA Negeri 4 yaitu Nurhidayati, S.Pd dan Dedi, S.Pd.yang berprofesi sebagai guru biologi di SMAN 4 Sumbawa. Secara rinci teknik pengambilan data akan disajikan dalam bentuk tabel dan dapat dilihat pada Tabel 3.2

Tabel 3.2 Teknik Pengumpulan Data

\begin{tabular}{|c|c|c|c|c|}
\hline No & Variabel & Instrumen & $\begin{array}{c}\text { Teknik } \\
\text { Pengumpulan data }\end{array}$ & Sumber data \\
\hline 1. & $\begin{array}{l}\text { Variabel bebas : } \\
\text { 1. } D V D 6 \mathrm{M} \text { melalui } \\
\quad P j B L\end{array}$ & $\begin{array}{ll}\text { a. } & \text { Silabus } \\
\text { b. } & \text { RPP } \\
\text { c. } & \text { LPKG } \\
\text { d. } & \text { LPKS } \\
\text { e. } & D V D 6 \mathrm{M} \\
\text { a. } & \text { Silabus } \\
\text { b. } & \text { RPP } \\
\text { c. } & \text { materi dari } \\
& \text { guru dibantu } \\
& \text { dengan power } \\
& \text { point }\end{array}$ & Pengamatan & $\begin{array}{ll}\text { - } & \text { Guru } \\
\text { - } & \text { Siswa }\end{array}$ \\
\hline \multirow[t]{4}{*}{2.} & $\begin{array}{l}\text { Variabel terikat: } \\
\text { kemampuan berpikir } \\
\text { kritis, Sikap, }\end{array}$ & $\begin{array}{l}\text { a. Instrument } \\
\text { kemampuan } \\
\text { berpikir kritis }\end{array}$ & $\begin{array}{l}\text { Pre tes } \\
\text { Pos test }\end{array}$ & Siswa \\
\hline & $\begin{array}{l}\text { Pengetahuan, dan } \\
\text { Keterampilan siswa }\end{array}$ & $\begin{array}{l}\text { b. Instrument tes } \\
\text { pengetahuan }\end{array}$ & $\begin{array}{l}\text { Pre tes } \\
\text { Pos test }\end{array}$ & Siswa \\
\hline & $\begin{array}{l}\text { dalam pengelolaan } \\
\text { sampah }\end{array}$ & $\begin{array}{l}\text { c. Instrument tes } \\
\text { sikap } \\
\text { d. Instrumen tes }\end{array}$ & $\begin{array}{l}\text { Pre tes } \\
\text { Pos test }\end{array}$ & Siswa \\
\hline & & $\begin{array}{l}\text { keterampilan } \\
\text { siswa dalam } \\
\text { pengelolaan } \\
\text { sampah }\end{array}$ & $\begin{array}{l}\text { Penilain laporan } \\
\text { produk }\end{array}$ & Siswa \\
\hline
\end{tabular}

\section{E. Analisis Data}

Data hasil penelitian yang menyangkut pengaruh strategi pembelajaran berbasis proyek berbantuan media $D V D 6 M$ terhadap kemampuan berpikir kritis, Sikap, pengetahuan, dan keterampilan dalam pengelolaan sampah. Akan di deskripsikan dengan menggunakan statistik deskriptif dan uji hipotesis dianalisis dengan kovarian (Anakova). Nilai pretest berperan sebagai kovariat. Sebelum analisis dilakukan, terlebih dahulu akan dilakukan uji prasyarat yang meliputi; uji 
normalitas data, uji homogenitas varians, dan uji sifat keterhubungan antara variabel tak bebas dengan kovariat.

Uji normaliatas yang digunakan dalam penelitian ini dengan menggunakan Kolmogorov-Smirnov Test dengan bantuan computer program SPSS for Windows versi 17. Apabila probalitas data sampel lebih besar dari 0,05 maka sampel tersebut dikategorikan normal. Uji homogenitas yang digunakan dalam penelitian ini menggunakan uji Leven's Test of Equality of Error Variances dengan bantuan komputer program SPSS for Windows versi 17. Pengujian hipotesis nol dilakukan pada taraf signifikansi $5 \%$. 


\section{BAB IV}

\section{HASIL PENELITIAN}

\section{A. Deskripsi Data}

\section{Keterlaksanaan Strategi Pembelajaran Berbasis Proyek Berbantuan Media DVD 6M}

Berdasarkan skenario pembelajaran berbasis proyek dapat dijelaskan bahwa keterlaksanaan strategi pembelajaran berbasis proyek berbantuan media DVD $6 M$ pada kelas eksperimen terdiri dari dua pokok bahasan yaitu keseimbangan lingkungan dan aktivitas manusia serta dampaknya terhadap lingkungan dan daur ulang limbah. Pembelajaran untuk dua pokok bahasan tersebut dilaksanakan dengan menggunakan strategi pembelajaran berbasis proyek berbantuan media $D V D 6 M$ selama enam kali pertemuan dengan perincian sebagai berikut.

\section{a. Pertemuan Pertama Januari 2012}

1) Persiapan Proyek

Persiapan proyek meliputi apersepsi yaitu guru menginformasikan tujuan pembelajaran pada pertemuan pertama guru memasuki kelas setelah memeriksa kesiapan siswa kemudian guru menginformasikan fenomena nyata sebagai sumber masalah sambil siswa memperhatikan tayangan media DVD $6 M$ siswa diberi hend out berupa format laporan proyek. Setelah itu siswa menyusun jadwal proyek kemudian siswa membuat dan menyepakati atauran kolaborasi didalam 
keseluruhan aktivitas proyek yang akan dilaksanakan. Gambar 4.1 menunjukan aktivitas siswa SMAN 1 ketika menonton video DVD $6 M$ terkait pengelolaan sampah.

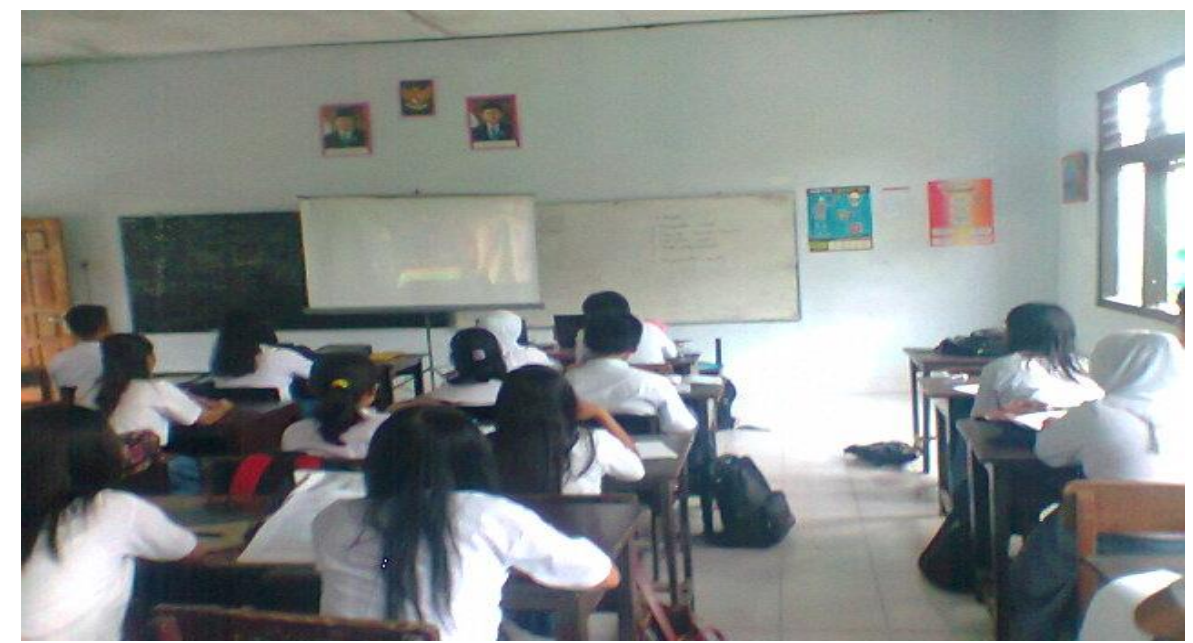

Gambar 4.1 Aktivitas Siswa SMAN I Ketika Menonton DVD 6M Terkait Pengelolaan Sampah

\section{b. Pertemuan Kedua Januari 2012}

2) Perencanaan proyek

Perencanaan proyek siswa melakukan pembentukan kelompok antara 4-5 orang, kemudian guru membimbing siswa mengidentifikasikan tema dan pemilihan proyek sesuai tema yaitu daur ulang limbah dengan konsep 6M setelah itu siswa mengumpulkan informasi yang relevan atau penelusuran sumber sesuai dengan tema yang dapatkan. Gambar 4.2 dan 4.3 menunjukan aktivitas siswa pada saat perencanaan proyek yang dipandu oleh guru bidang studi SMAN 1 Sumbawa Besar dan aktivitas siswa pada saat perencanaan proyek di SMAN 3 Sumbawa yang dipandu oleh peneliti. Selanjutnya siswa bekerja secara berkelompok menyusun rencana investigasi merumuskan masalah sesuai tema yang dipilih (dilakukan diluar jam pelajaran) dan menyusun hipotesis, 
menentukan variabel menyusun instrumen dan prosedur penelitian. Gambar 4.4 Menujukan kegiatan siswa ketika menyusun rencana proyek berdasarkan tema yang dipilih oleh masing-masing kelompok.

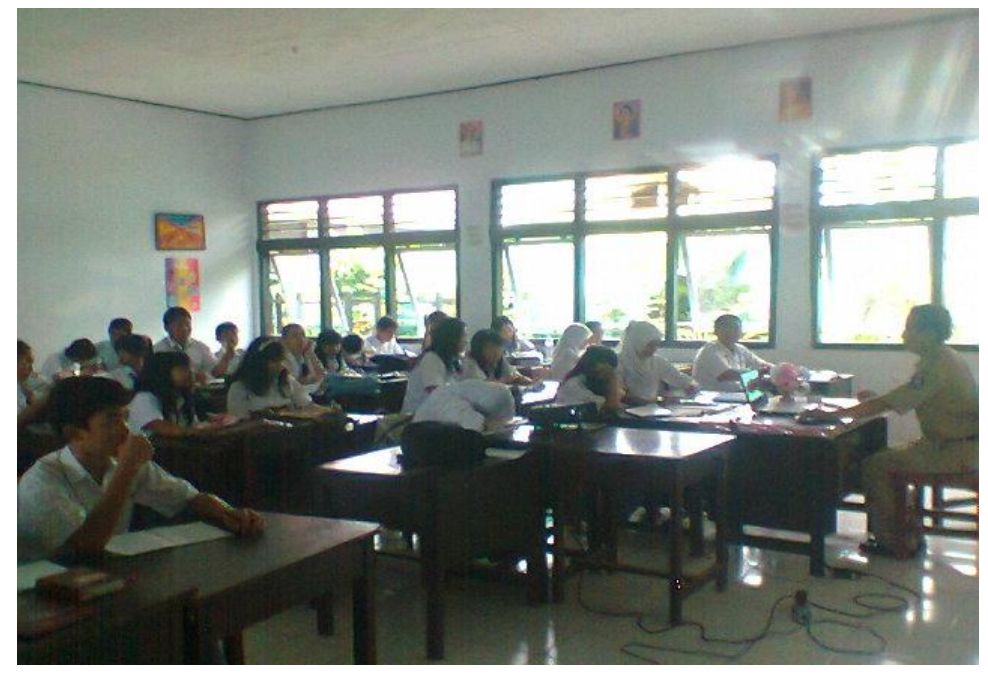

Gambar 4.2 Aktivitas Siswa Pada Saat Melakukan Perencanaan Proyek di SMAN 1 Sumbawa Besar

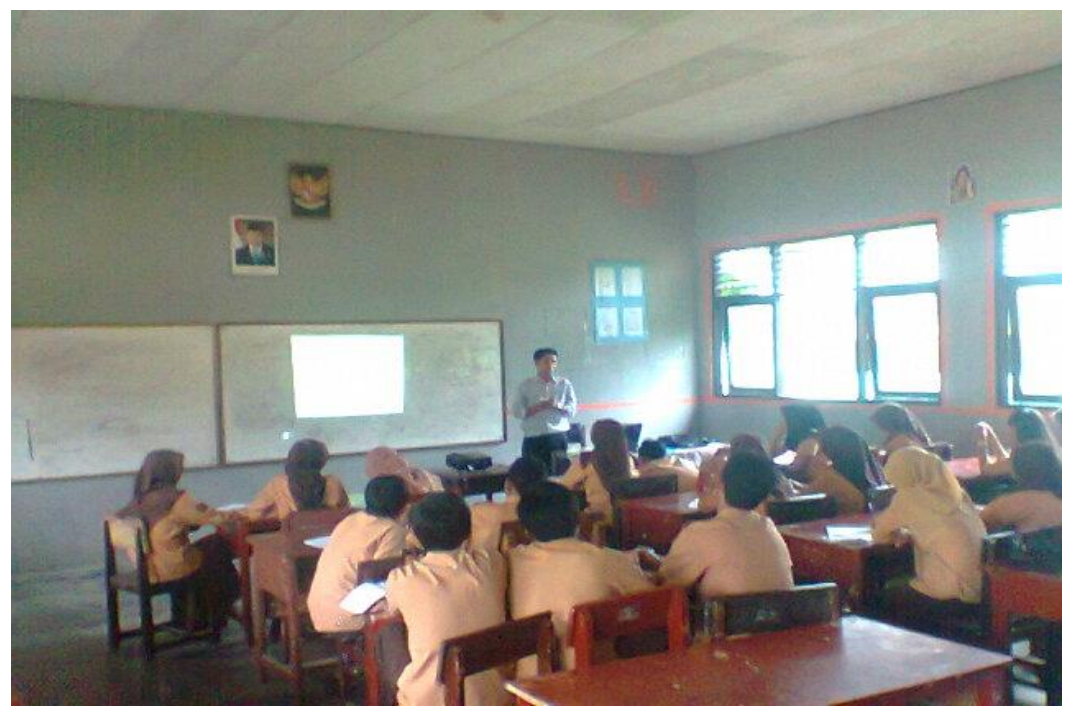


Gambar 4.3 Aktivitas Siswa Pada Saat melakukan Perencanaan Proyek di SMAN 3 Sumbawa Besar

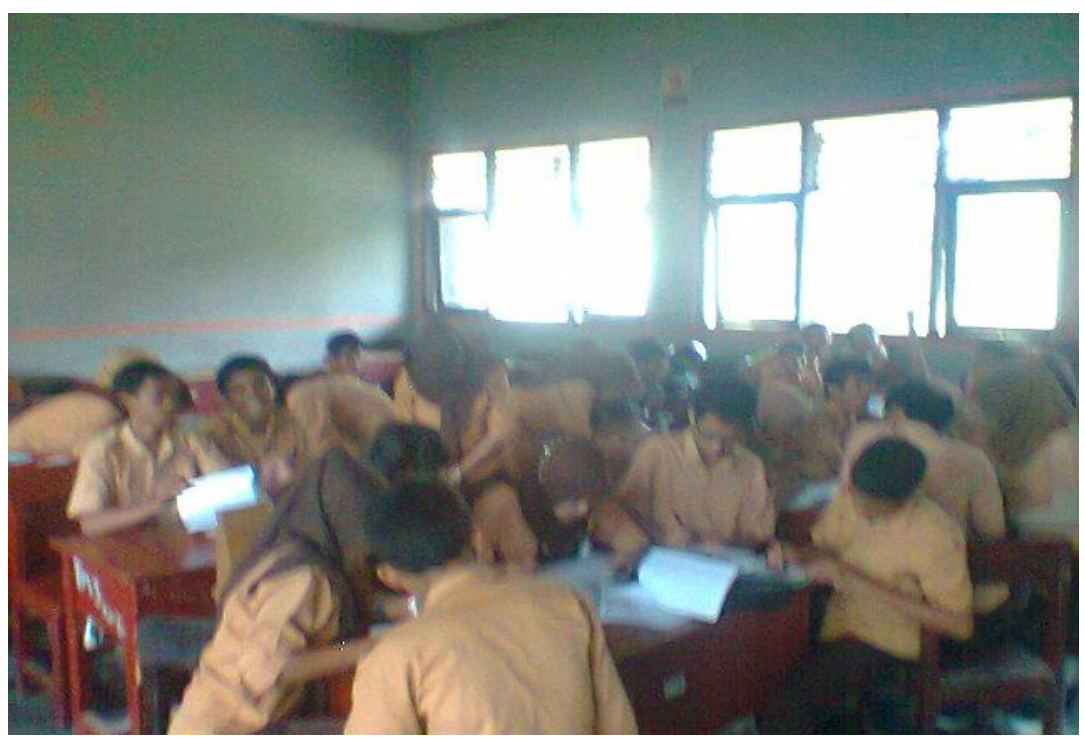

Gambar 4.4 Kegiatan Siswa Sedang Berdiskusi Menyusun Rencana Kegiatan Proyek Yang Akan Dikerjakan Diluar Jam Pelajaran

\section{c. Petemuan Ketiga Januari 2012}

3) Pelaksanaan Proyek

Pelaksaan proyek yang dilakukan oleh siswa yaitu mengorganisasikan kegiatan belajar mengajar (penugasan diluar jam pelajaran dibimbing guru melalui pengamatan dan diskusi secara berkelompok kemudian siswa melakukan investigasi mengumpulkan data sesuai tema yang dipilih yaitu daur ulang limbah dengan konsep 6M merupakan suatu upaya pengelolaan sampah rumah tangga yang ter diri atas beberapa langkah yaitu: Mengurangi berarti suatu uapaya mengurangi jumlah sampah yang kita timbulka, Menggunakan kembali berarti memakai atau memanfaatkan kembali sampah rumah tangga, Mengganti berarti mengganti jenis bahan kebutuhan rumah tangga tertentu dengan jenis bahan yang lain, Memisahkan berarti memisahkan sampah rumah tangga antara sampah basah 
dan sampah kering yang sejenis, Mendaur ulang bearti memanfaatkan kembali sampah rumah tangga dengan mengelolah terlebih dahulu, dan Mengomposkan artinya suatu uapaya mengelolah sampah rumah tangga menjadi kompos. Gambar 4.5 menunjukan kegiatan salah satu anggota kelompok siswa SMAN I Sumbawa Ketika pelaksanaan proyek

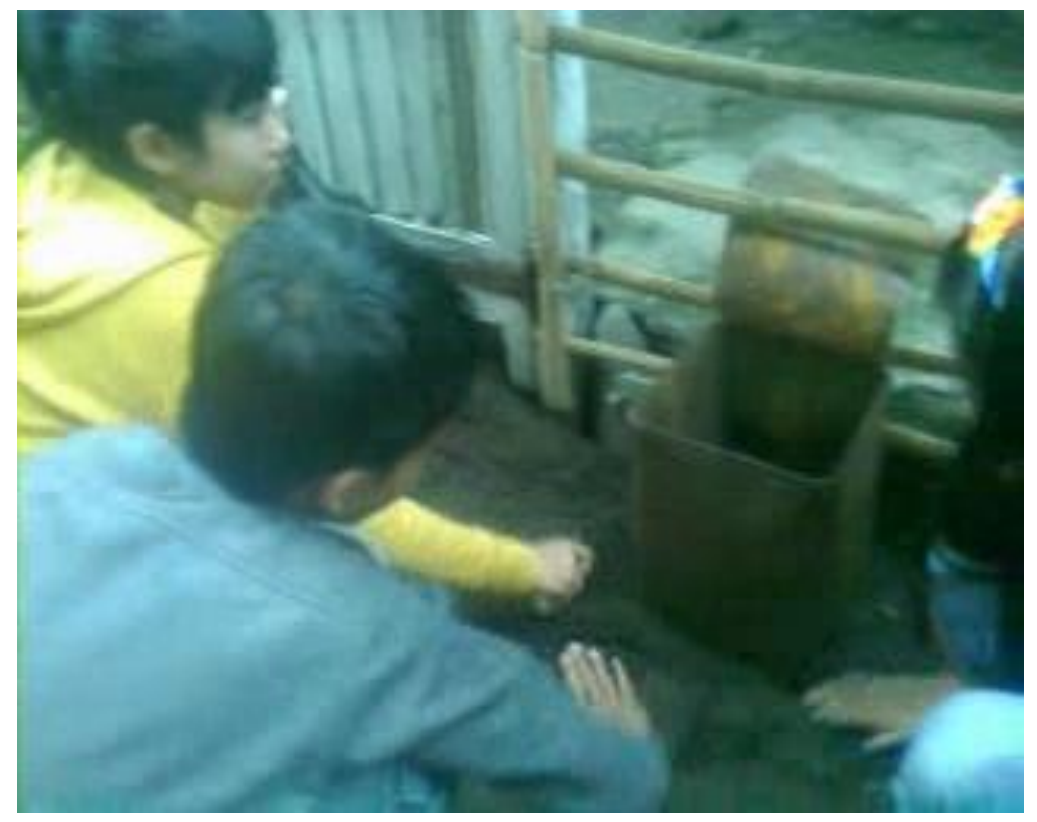

\section{Gambar 4.5 Kegiatan Mengomposkan Sampah Siswa SMAN 3 Sumbawa Besar Ketika Pelaksanaan Proyek}

\section{Pertemuan Keempat Januari 2012}

Pada pertemuan keempat yang dilakukan oleh siswa adalah melakukan kerjasama menyiapkan presentasi/mensyusun laporan ilmiah hasil investigasi atau membuat artifak lainya. Setelah peserta didik melakukan investigasi di luar sekolah maka dengan penuh percaya diri siswa mampu melakukan menganalisis data yang di teliti kemudian siswa mampu menarik kesimpulan dengan cermat dengan rasa percaya diri siswa mampu mengkomunikasikan gagasan atau temuan yang didapatkan pada saat investigasi dengan anggota kelompok yang dilakukan diluar jam pelajaran. Gambar 4.6 menunjukan aktivitas diskusi kelompok sambil 
mengkomunikasikan gagasan atau temuan kelompok sesuai hasil investigasi yang telah mereka lakukan diluar jam pelajaran di gambar dibawah ini di ambil di SMAN 4 kota Sumbawa Besar.

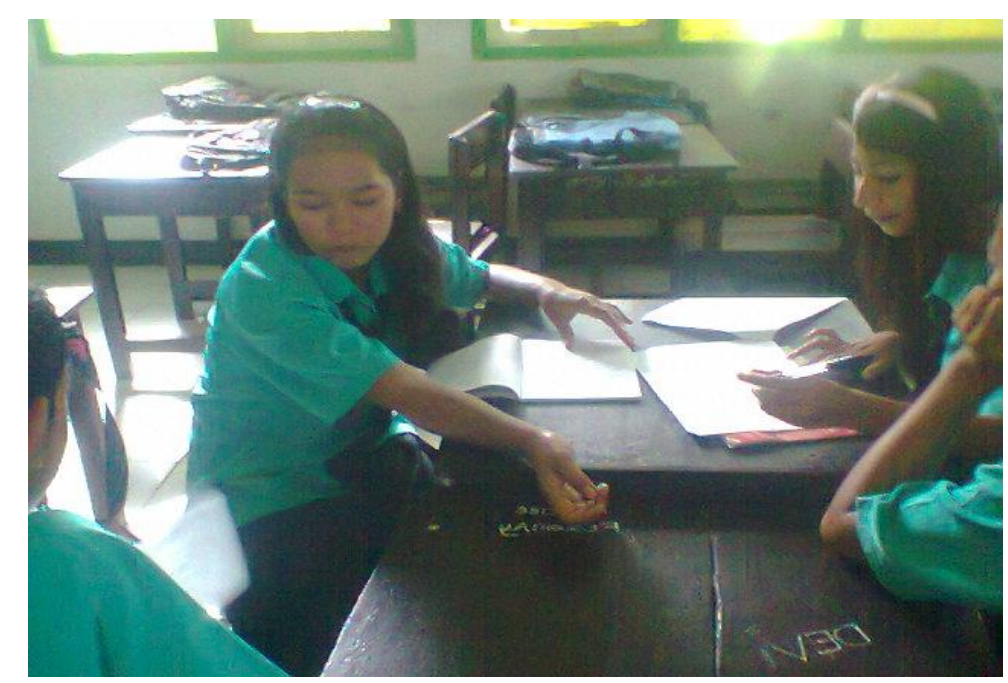

Gambar 4.6 Diskusi Kelompok Sambil Mengkomunikasikan Gagasan atau Temuan Kelompok di SMAN 4 Sumbawa Besar

\section{Pertemuan Kelima Januari 2012}

d) Presentasi Proyek

Presentasi hasil proyek dilakukan oleh siswa secara berkelompok didapan kelas dalam penyajian laporan proyek (artifak) dibimbing guru yaitu presentasi proyek diskusi didepan kelas sesuai tema yaitu hasil daur ulang limbah dengan menerapkan konsep 6M. Gambar 4.7 menunjukan aktivitas siswa pada saat presentasi hasil proyek daur ulang sampah di SMAN 1 Sumbawa Besar 


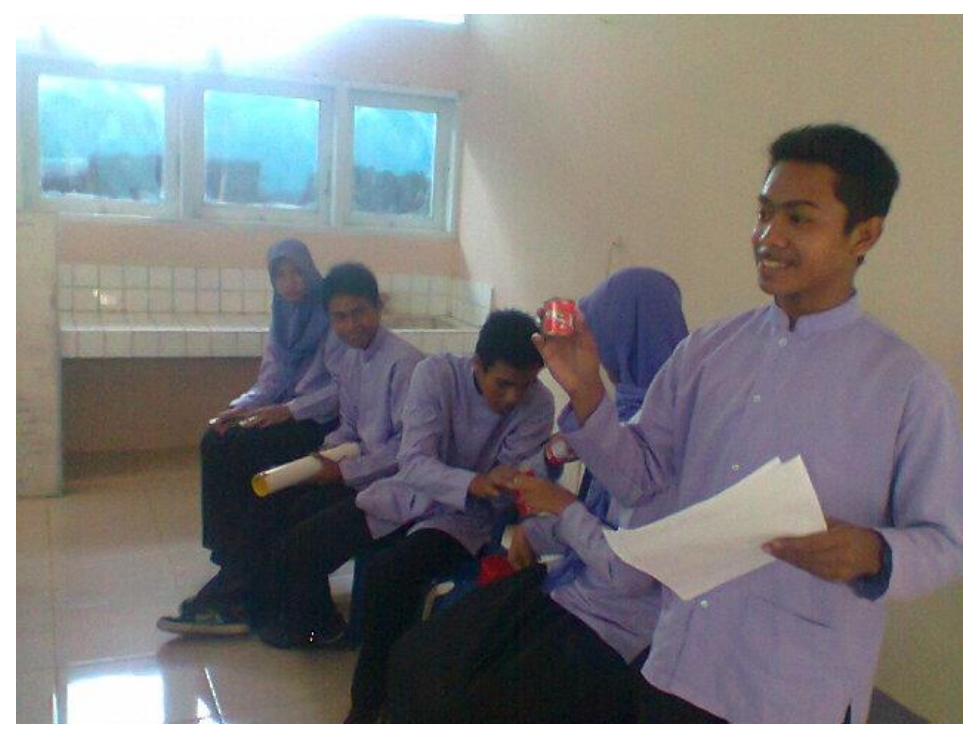

Gambar 4.7 Presentasi Hasil Proyek di SMAN I Sumbawa Besar 6. Pertemuan Keenam Februari 2012

e) Evaluasi

Tahap evaluasi atau tahap refleksi untuk mengevaluasi proses Peraktik Belajar Mengajar (PBM) dengan strategi pembelajaran berbasis proyek sebagai acuan tindak lanjut evaluasi proses menggunakan evaluasi dari sendiri, evaluasi teman sebaya, dan fortopolio selama pembelajaran mulai dari pertemuan I sampai dengan pertemuan terakhir.

Berdasarkan hasil keterlaksanaan strategi pembelajaran berbasis proyek berbantuan DVD $6 M$ yang diukur dengan menggunakan lembar observasi, bertujuan untuk mengetahui keterlaksanaan tahap-tahap pada pembelajaran berbasis proyek yang telah dilaksanakan. Observasi dilakukan oleh guru pengajar sebagai peneliti dan dibantu oleh dua orang observer (guru biologi SMAN Kota Sumbawa Besar tahun 2012). Hasil observasi didapatkan, persentase rata-rata 
keterlaksanaan strategi pembelajaran berbasis proyek berbantuan $D V D 6 M$ pada siswa SMAN Kota Sumbawa Besar tahun 2012 tertera pada Tabel 4.1

Tabel 4.1 Rata-rata Keterlaksanaan Pembelajaran Berbasis Proyek Berbantuan Media DVD 6M Tiga Sekolah Kelas Eksperimen di SMAN Kota Sumbawa Besar

\begin{tabular}{clc}
\hline No & \multicolumn{1}{c}{ SintakPjBL } & Persentase Keterlaksaan \\
\hline 1 & Persiapan Proyek & 100 \\
\hline 2 & Perencanaan proyek & 100 \\
\hline 3 & Pelaksanaan proyek & 100 \\
\hline 4 & Presentasi hasil proyek & 75 \\
\hline 5 & Evaluasi & 100 \\
\hline & Nilai Rata-rata & 95,0 \\
\hline
\end{tabular}

Sumber: Lampiran 7

Berdasarkan Tabel 4.1 dapat dijelaskan bahwa tingkat keterlaksanaan strategi pembelajaran berbasis proyek berbantuan media $D V D 6 M$ di SMAN Kota Sumbawa Besar tahun 2012 diperoleh rata-rata persentase keterlaksanaan pembelajaran sebesar 95,0\%. Artinya secara keseluruhan tahap-tahap pembelajaran dengan strategi pembelajaran berbasis proyek sesuai dengan yang direncanakan dalam skenario pembelajaran berbasis proyek dapat dilaksanakan oleh guru telah dilakukan dengan kategori sangat baik.

\section{Keterlaksanaan Pembelajaran Kelas Konvensional}

Keterlaksanaan pembelajaran kelas konvensional dilakukan oleh peneliti di SMAN Kota Sumbawa Besar tahun 2012 dengan menggunakan lembar observasi keterlaksanaan pembelajaran konvensional. Hasil observasi keterlaksanaan pembelajaran kelas konvensional yang dilakukan oleh peneliti di SMAN Kota Sumbawa Besar tahun 2012 tertera pada Tabel 4.2 
Tabel 4.2 Rata-rata Persentase Keterlaksanaan Pembelajaran dari Tiga Sekolah Kelas

\begin{tabular}{clc}
\multicolumn{3}{c}{ Konvensional di SMAN Kota Sumbawa Besar } \\
\hline No & \multicolumn{1}{c}{ Skenario PBM } & Persentase \\
\hline 1 & Pendahuluan (Apersepsi) & 100 \\
\hline 2 & Penyampaia materi & 100 \\
\hline 3 & Kegiatan Inti & 67,5 \\
\hline 4 & Metode ceramah dan diskusi & 100 \\
\hline 5 & Penutup (Evaluasi) & 100 \\
\hline & & 93,5 \\
\hline
\end{tabular}

Sumber: Lampiran 8

Berdasarkan Tabel 4.2 dari hasil observasi pelaksanaan pembelajaran pada kelas konvensioanal dapat dijelaskan bahwa tingkat keterlaksanaan pembelajaran kelas konvensional diperoleh rata-rata persentase keterlaksanaan pembelajaran sebesar 93,5\% dengan kategori sangat baik.

\section{Kemampuan Berpikir Kritis Siswa SMAN Kota Sumbawa Besar dalam Pengelolaan lingkungan}

Berdasarkan hasil tes kemampuan berpikir kritis siswa didapatkan rata-rata nilai pretes dan rata-rata nilai postes kemampuan berpikir kritis siswa SMAN kota Sumbawa Besar dalam pengelolaan lingkungan disajikan dalam Tabel 4.2 berikut.

Tabel 4.3 Rata-rata Kemampuan Berpikir Kritis Siswa SMAN Kota Sumbawa Besar

\begin{tabular}{ccccccc}
\hline No & Kelas & $\begin{array}{c}\text { Rata-rata } \\
\text { Nilai Pretes }\end{array}$ & Kategori & $\begin{array}{c}\text { Rata-rata } \\
\text { Nilai Postes }\end{array}$ & Kategori & Persentase \\
\hline 1 & Eksperimen & 47,2 & Sedang & 66,2 & Baik & 40,3 \\
\hline 2 & Kontrol & 46,2 & Sedang & 63,5 & Baik & 37,4 \\
\hline
\end{tabular}

Sumber:Lampiran 12

Berdasarkan Tabel 4.3 dapat dijelaskan rata-rata nilai kemampuan berpikir kritis siswa pada kelas eksperimen cendrung lebih besar daripada kelas kontrol. Rata-rata nilai pretes kemampuan berpikir kritis siswa SMAN Kota Sumbawa Besar pada kelas eksperimen sebesar 47,2 dengan kategori sedang, sedangkan rata-rata nilai postes kemampuan berpikir kritis siswa SMAN Kota Sumbawa Besar sebesar 66,2 dengan kategori baik. Pada kelas kontrol rata-rata nilai pretes 
kemampuan berpikir kritis siswa SMAN Kota Sumbawa Besar tahun 2012 sebesar 46,2 dengan kategori sedang, dan rata-rata nilai postes kemampuan berpikir kritis siswa SMAN Kota Sumbawa Besar sebesar 63,5 dengan kategori baik.

Persentase peningkatan pada kelas eksperimen antara rata-rata pretes dan postes sebesar 40,3\%, pada kelas kontrol persentase peningkatan antara pretes dan postes sebesar $37,4 \%$. Rata-rata nilai pretes dan postes kemampuan berpikir kritis siswa SMAN Kota Sumbawa Besar tahun 2012 pada kelas eksperimen dan kelas kontrol disajikan dalam Gambar 4.8

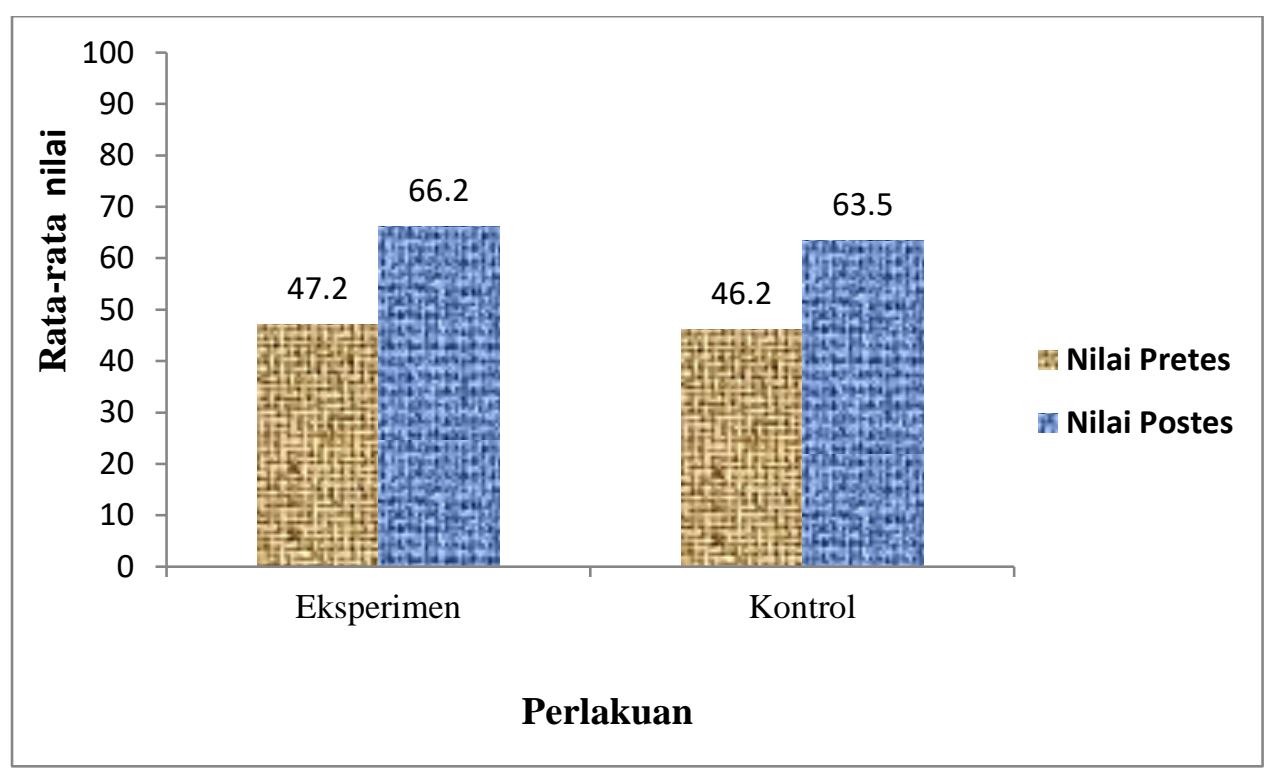

Gambar 4.8 Rata-rata Kemampuan Berpikir Kritis Siswa Pada Kelas Eksperimen dan Kelas Kontrol SMAN Kota Sumbawa Besar (Sumber: Lampiran 12)

Berdasarkan nilai kemampuan berpikir kritis setiap indikator kemampuan berpikir kritis yaitu, kemampuan berpendapat, kemampuan membandingkan, kemampuan memberikan alasan, kemampuan menyimpulkan, kemampuan mengelompokan,dan kemampuan menganalisis didapatkan rata-rata nilai setiap indikator kemampuan berpikir kritis yang tertera pada Tabel 4.4 dan 4.5 berikut. 
Tabel 4.4 Rata-rata Nilai Setiap Indikator Kemampuan Berpikir Kritis Pada Tiga Kelas Eksperimen

\begin{tabular}{rlccccc}
\hline \multicolumn{1}{c}{ No } & Indikator & Pretes & Kategori & Postes & Kategori & Persentase \\
\hline 1 & Sebab Akibat & 47,8 & Sedang & 73,2 & Baik & 53,1 \\
\hline 2 & Memberikan alasan & 46,2 & Sedang & 65,2 & Baik & 41,1 \\
\hline 3 & Berpendapat & 47,9 & Sedang & 63,0 & Baik & 31,5 \\
\hline 4 & Mengelompokan & 49,9 & Sedang & 64,6 & Baik & 29,5 \\
\hline 5 & Menganalisis & 41,9 & Sedang & 64,4 & Baik & 53,7 \\
\hline
\end{tabular}

Sumber: Lampiran 13

Berdasarkan Tabel 4.4 dapat dijelaskan bahwa peserta didik yang belajar dengan pembelajaran berbasis proyek berbantuan media $D V D 6 M$ cendrung mengalami kenaikan rerata rata-rata pretes dan postes. Kenaikan nilai rata-rata kemampuan berpikir kritis tertinggi kelas eksperimen yaitu indikator sebab akibat, dengan nilai pretes sebesar 47,8 kategori sedang dan postes 73,2 kategori baik. Artinya siswa mampu menjawab dengan baik faktor-faktor penyebab terjadinya kerusakan lingkungan. Jawaban indikator sebab akibat yaitu terjadinya pencemaran secara alami dan pencemaran lingkungan secara buatan atau oleh ulah perbuatan manusia seperti pencemaran udara, pencemaran air, pembuangan sampah tidak pada tempatnya, pencemaran daratan, terjadinya tanah longsor, terjadinya erosi, eksploetasi Sum ber daya alam dan lain-lain.

Nilai rata-rata kemampuan berpikir kritis terendah yaitu indikator berpendapat dengan nilai pretes sebesar 47,9 kategori sedang, dan nilai postes 63,0 kategori baik, sedangkan persentase peningkatan tertinggi pada kelas eksperimen terdapat pada indikator menganalisis sebesar $53,7 \%$. Persentase peningkatan terendah terdapat pada indikator mengelompokan sebesar $29,5 \%$. Rata-rata skor kemampuan berpikir kritis pretes dan postes pada kelas kontrol beserta kategorinya dapat dijelaskan pada Gambar 4.9 


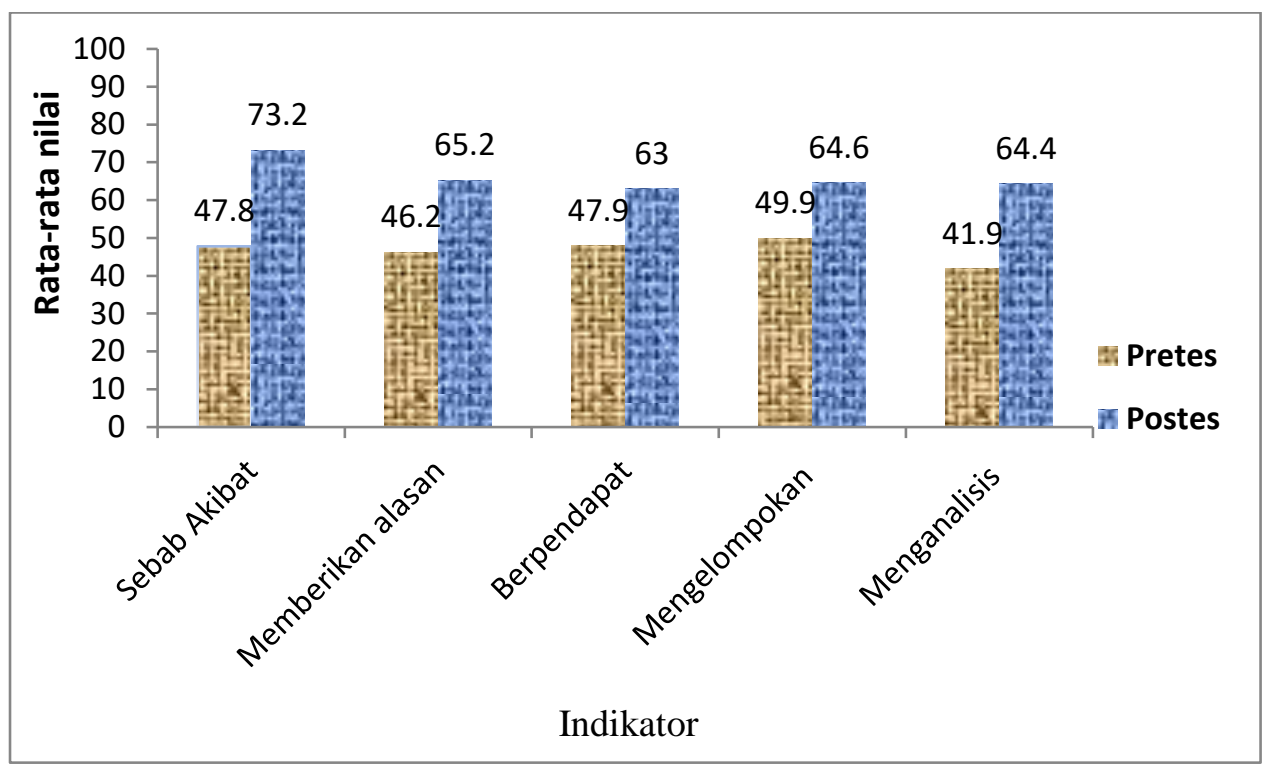

Gambar 4.9 Rata-rata Nilai Setiap Aspek Kemampuan Berpikir Siswa SMAN Kota Sumbawa Besar pada Kelas Eksperimen (Sumber: Lampiran 13 )

Tabel 4.5 Rata-rata Nilai Setiap Indikator Kemampuan Berpikir Kritis pada Tiga Kelas Kontrol

\begin{tabular}{rlrlllc}
\hline No & Indikator & Pretes & Kategori & Postes & Kategori & Persentase \\
\hline 1 & Sebab akibat & 42,4 & Sedang & 61,7 & Baik & 45,5 \\
\hline 2 & Memberikan alasan & 39,4 & Sedang & 54,4 & Sedang & 28,3 \\
\hline 3 & Berpendapat & 51,0 & Sedang & 68,1 & Baik & 33,3 \\
\hline 4 & Mengelompokan & 46,5 & Sedang & 64,1 & Baik & 38,9 \\
\hline 5 & Menganalisis & 43,3 & Sedang & 59,1 & Sedang & 36,5 \\
\hline Sumber: Lampiran 14 & & & & &
\end{tabular}

Berdasarkan Tabel 4.5 dapat dijelaskan bahwa peserta didik yang belajar dengan strategi pembelajaran berbasis proyek berbantuan media $D V D 6 M$ terjadi kenaikan rata-rata skor pretes dan postes. Kenaikan skor kemampuan berpikir kritis tertinggi kelas kontrol terdapat pada indikator berpendapat dengan nilai pretes 51,0 kategori sedang dan postes 68,1 kategori baik. Persentase peningkatan sebesar 33,3\%. Nilai rata-rata kemampuan berpikir kritis terendah pada indikator 
memberikan alasan dengan skor pretes sebesar 39,4 kategori sedang dan skor postes sebesar 54,4 kategori sedang dengan persentase peningkatan 28,3\%. Ratarata skor kemampuan berpikir kritis pretes dan postes pada kelas kontrol beserta kategorinya dapat dijelaskan pada Gambar 4.10

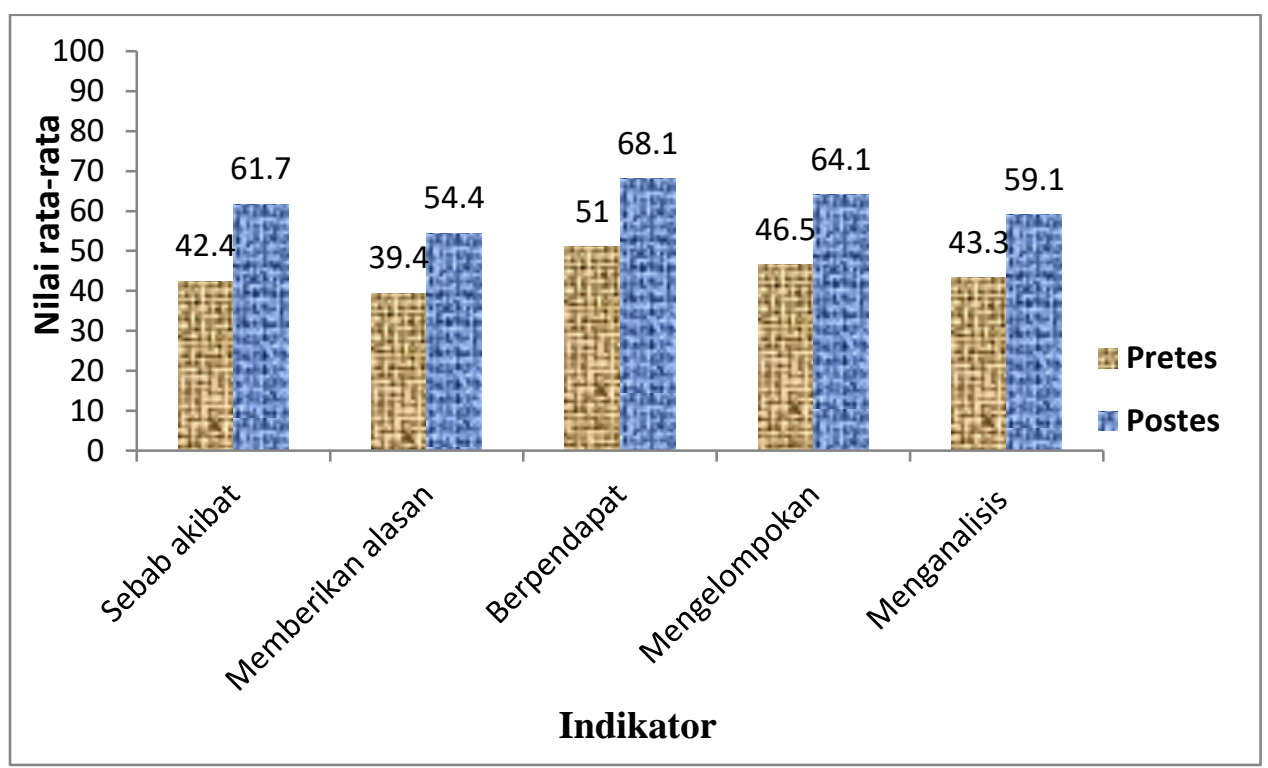

Gambar 4.10 Rata-rata Nilai Setiap Aspek Kemampuan Berpikir Siswa SMAN Kota Sumbawa Besar Kelas Kontrol (Sumber: Lampiran 14)

\section{Pengetahuan Siswa SMAN Kota Sumbawa Besar dalam Pengelolaan Lingkungan}

Rata-rata nilai pengetahaun siswa SMAN Kota Sumbawa Besar tahun 2012 dalam pengelolaan lingkungan tertera pada Tabel 4.6

Tabel 4.6 Rata-rata Pengetahuan Siswa SMAN Kota Sumbawa Besar pada Kelas Eksperimen dan Kelas Kontrol

\begin{tabular}{ccccccc}
\hline No & Kelas & $\begin{array}{c}\text { Rata-rata } \\
\text { Nilai Pretes }\end{array}$ & Kategori & $\begin{array}{c}\text { Rata-rata } \\
\text { Nilai Postes }\end{array}$ & Kategori & Persentase \\
\hline 1 & Eksperimen & 50,4 & Sedang & 71,3 & Baik & 41,5 \\
\hline 2 & Kontrol & 47,2 & Sedang & 65,9 & Baik & 39,6 \\
\hline
\end{tabular}

Sumber: Lampiran 15

Berdasarkan Tabel 4.6 bahwa rata-rata nilai pengetahuan siswa pada kelas eksperimen cendrung lebih besar daripada kelas kontrol. Rata-rata nilai pretes 
pengetahuan siswa SMAN Kota Sumbawa Besar tahun 2012 pada kelas eksperimen sebesar 50,4 dengan kategori sedang, sedangkan rata-rata nilai postes pengetahuan sebesar 71,3 dengan kategori baik. Pada kelas kontrol rata-rata nilai pretes pengetahuan siswa SMAN Kota Sumbawa Besar tahun 2012 sebesar 47,2 dengan kategori sedangkan, rata-rata nilai postes kemampuan berpikir kritis siswa sebesar 65,9 dengan kategori baik.

Persentase peningkatan pengetahuan pada SMAN Kota Sumbawa Besar tahun 2012 Cendrung lebih tinggi dibanding kelas kontrol, pada kelas eksperimen sebesar $41,5 \%$, sedangkan pada kelas kontrol rata-rata persentse peningkatan sebesar 39,6\%. Artinya lebih baik pembelajaran yang diberi strategi pembelajaran berbaisis proyek berbantuan media $D V D 6 M$ dibanding dengan yang kelas yang diberi pembelajaran konvensional. Rata-rata nilai pengetahuan pretes dan postes pada kelas eksperien dan kontrol dapat dijelaskan pada Gambar 4.11

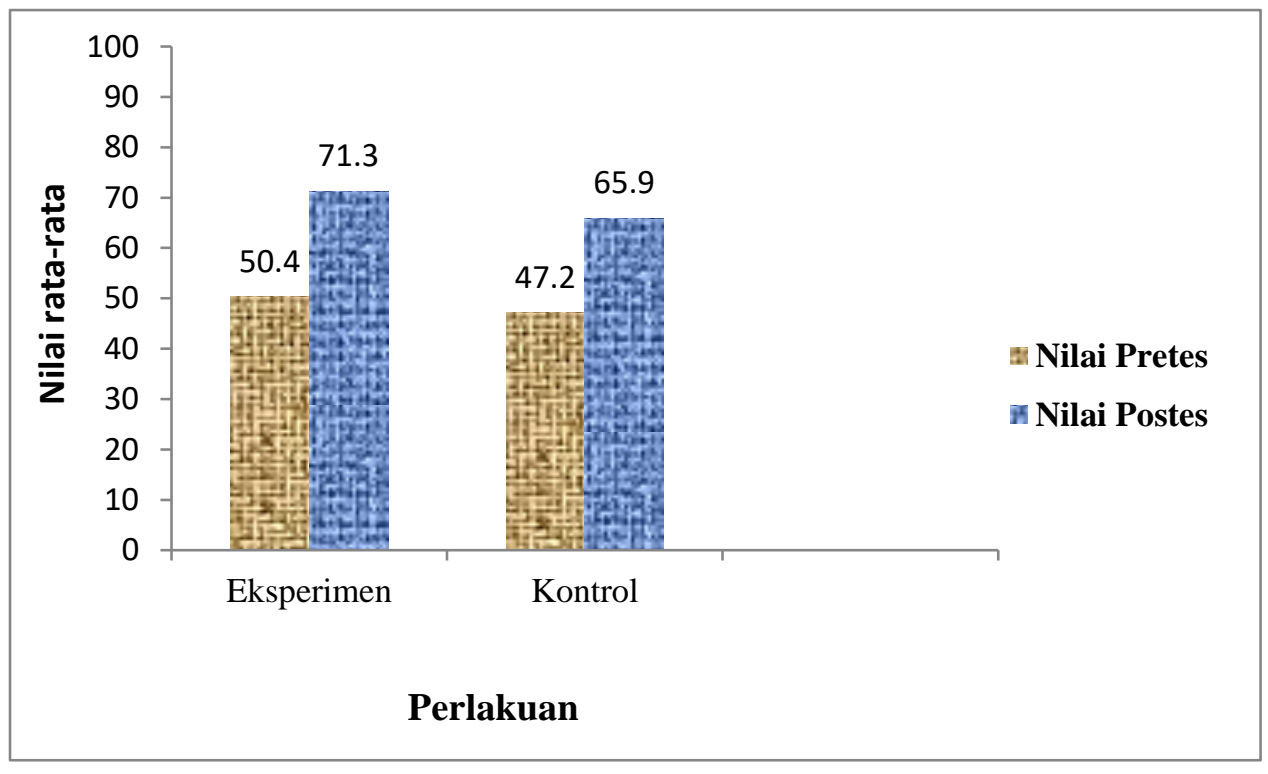

Gambar 4.11 Rata-rata Pengetahuan Siswa pada Kelas Eksperimen dan Kelas Kontrol SMAN Kota Sumbawa Besar (Sumber: Lampiran 15) 
Berdasarkan nilai rata-rata yang di dapatkan setiap indikator pengetahuan yaitu C2 (memahami), C3 (menerapkan), C4 (menganalisis), C5 (mengevaluasi) dan C6 (menciptakan). Maka didapatkan rata-rata nilai setiap indikator pengetahuan siswa SMAN Kota Sumbawa Besar pada kelas eksperimen dan kelas kontrol tertera pada Tabel 4.7 dan Tabel 4.8 berikut.

Tabel 4.7 Rata-rata Nilai Setiap Indikator Pengetahuan Siswa SMAN Kota Sumbawa Besar pada Tiga Kelas Eksperimen

\begin{tabular}{ccccccc}
\hline No & $\begin{array}{c}\text { Indikator } \\
\text { Pengetahuan }\end{array}$ & $\begin{array}{c}\text { Rata-rata } \\
\text { Pretes }\end{array}$ & Kategori & $\begin{array}{c}\text { Rata-rata } \\
\text { Postes }\end{array}$ & Kategori & Persentase \\
\hline 1 & C2 & 61,5 & Baik & 81,0 & Sangat Baik & 31,7 \\
\hline 2 & C3 & 53,8 & Sedang & 71,2 & Baik & 32,3 \\
\hline 3 & C4 & 53,1 & Sedang & 69,3 & Baik & 30,5 \\
\hline 4 & C5 & 44,3 & Sedang & 68,7 & Baik & 55,1 \\
\hline 5 & C6 & 41,9 & Sedang & 66,9 & Baik & 59,7 \\
\hline
\end{tabular}

Sumber: Lampiran 16

Tabel 4.8 Rata-rata Nilai Setiap Indikator Pengetahuan Siswa SMAN Kota Sumbawa Besar pada Kelas Kontrol

\begin{tabular}{ccccccc}
\hline No & $\begin{array}{c}\text { Indikator } \\
\text { Pengetahuan }\end{array}$ & $\begin{array}{c}\text { Rata-rata } \\
\text { Pretes }\end{array}$ & Kategori & $\begin{array}{c}\text { Rata-rata } \\
\text { Postes }\end{array}$ & Kategori & Persentase \\
\hline 1 & C2 & 56,6 & Sedang & 74,1 & Baik & 30,9 \\
\hline 2 & C3 & 45,2 & Sedang & 64,3 & Baik & 42,3 \\
\hline 3 & C4 & 42,9 & Sedang & 60,0 & Baik & 39,9 \\
\hline 4 & C5 & 44,5 & Sedang & 64,2 & Baik & 44,3 \\
\hline 5 & C6 & 51,7 & Sedang & 71,2 & Baik & 37,7 \\
\hline
\end{tabular}

Sumber: Lampiran 17

Berdasarkan Tabel 4.7 dan 4.8 dapat dijelaskan bahwa terjadi kacendrungan kenaikan rerata nilai pretes dan postes. Kenaikan rata-rata pengetahuan tertinggi pada kelas eksperimen saat pretes yaitu indikator memahami (C2) dengan nilai pretes sebesar 61,5 kategori baik, dan postes sebesar 81,0 kategori Sangat baik. Artinya siswa dapat memahami dengan baik mengenai bahan-bahan polutan dijalan raya. Jawabannya yaitu Carbon Monoksida (CO), 
Hidrogen Oksida (HO), Hidrokarbon (HC), Karbon diaoksida (CO2), Bahan bakar posil, dan lain lain. Nilai rata-rata terendah pada indikator C6 dengan nilai pretes 41,9 kategori sedang dan postes sebesar 66,9 kategori baik. Persentase peningkatan tertinggi terdapat pada indikator C6 sebesar 59,7\%. Disusul oleh indikator C5 sebesar 55,1\%, indikator C3 sebesar 32,3\%, indikator C2 sebesar $31,7 \%$, dan indikator $\mathrm{C} 4$ sebesar $30,5 \%$.

Berdasarkan Tabel 4.7 dan 4.8 rata-rata nilai pretes dan postes untuk setiap indikator pengetahuan pada kelas eksperimen cendrung lebih tinggi dari kelas kontrol artinya siswa yang diberi strategi pembelajaran berbasis proyek berbantuan media DVD 6M berbeda dengan kelas konvensional.. Berdasarkan Tabel 4.8 Rata-rata nilai pengetahuan pretes dan postes pada kelas kontrol beserta kategorinya dapat dijelaskan pada Gambar 4.12 dan Gambar 4.13

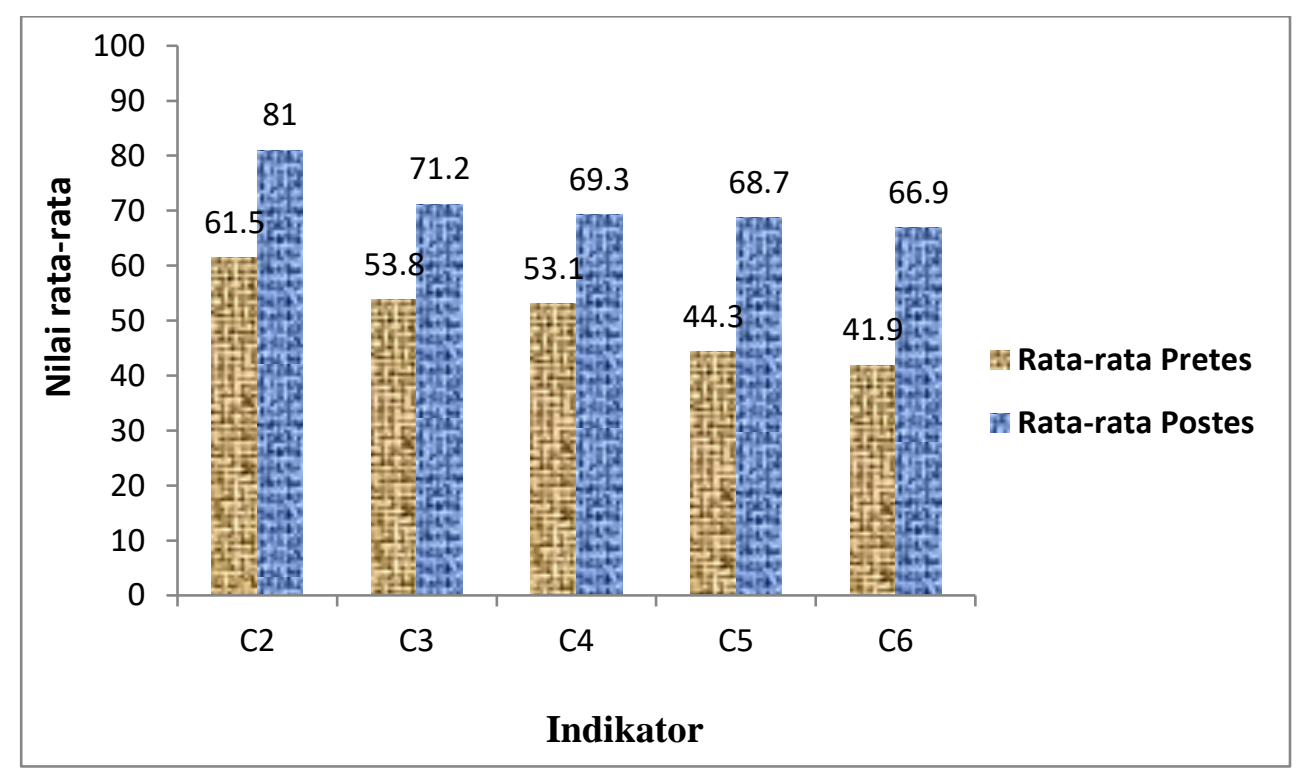

Gambar 4.12 Rata-rata Nilai Setiap Aspek Pengetahuan Siswa SMAN Kota Sumbawa Besar pada Kelas Eksperimen (Sumber: Lampiran 16) 


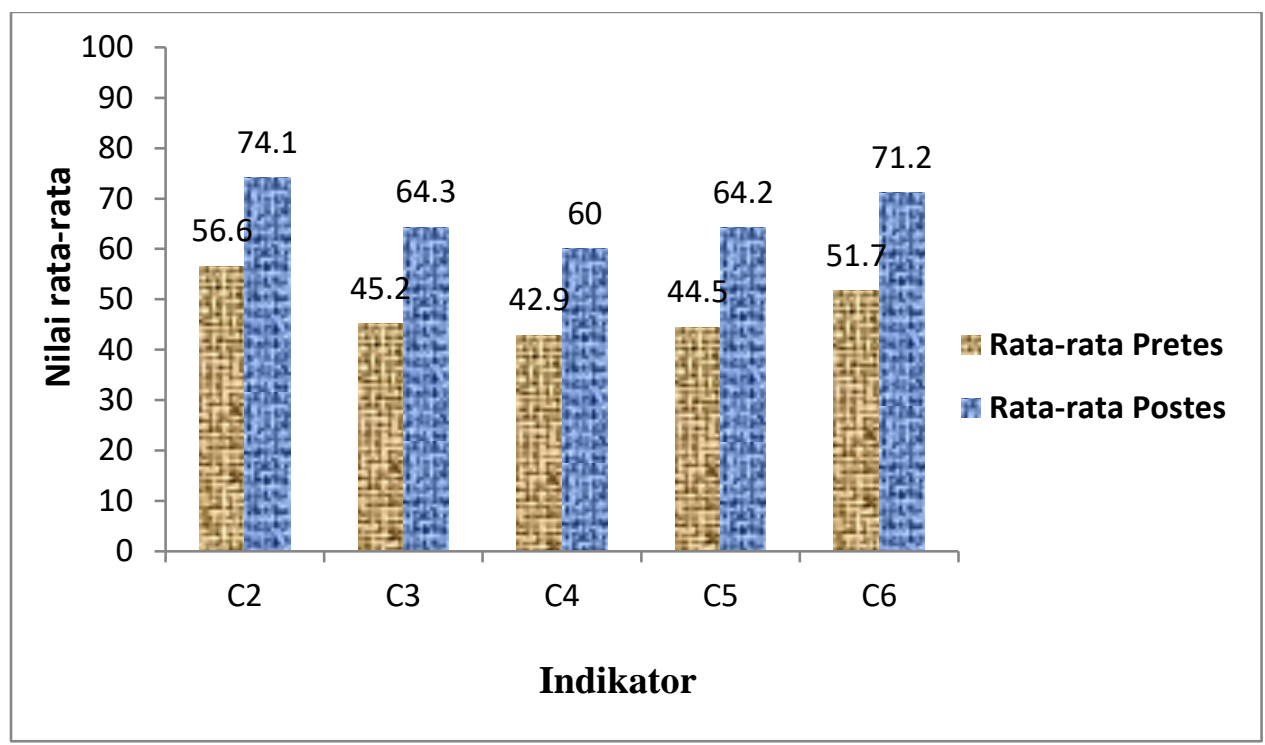

Gambar 4.13 Rata-rata Nilai Setiap Aspek Pengetahuan Siswa SMAN Kota Sumbawa Besar pada Kelas Kontrol (Sumber: Lampiran 17)

\section{Sikap Siswa SMAN Kota Sumbawa Besar dalam Pengelolaan Lingkungan}

Rata-rata nilai sikap siswa SMAN Kota Sumbawa Besar tahun 2012 dalam pengelolaan lingkungan tertera pada Tabel 4.9

Tabel 4.9 Rata-rata Sikap Siswa Kelas Eksperimen dan Kontrol SMAN Kota Sumbawa

\begin{tabular}{ccccccc}
\hline No & Kelas & $\begin{array}{c}\text { Rata-rata } \\
\text { Nilai Pretes }\end{array}$ & Kategori & $\begin{array}{c}\text { Rata-rata } \\
\text { Nilai Postes }\end{array}$ & Kategori & Persentase \\
\hline 1 & Eksperimen & 54,1 & Sedang & 74,7 & Baik & 38,1 \\
\hline 2 & Kontrol & 51,4 & Sedang & 67,2 & Baik & 30,7 \\
\hline
\end{tabular}

Sumber: Lampiran 18

Berdasarkan Tabel 4.9 dapat dijelaskan bahwa rata-rata nilai pretes sikap siswa SMAN Kota Sumbawa Besar tahun 2012 pada kelas eksperimen sebesar 54,1 kategori sedang sedangkan rata-rata nilai postes sikap siswa SMAN Kota 
Sum bawa Besar tahun 2012 sebesar 74,7 kategori baik. Sedangkan pada kelas kontrol rata-rata nilai pretes sikap siswa SMAN Kota Sumbawa Besar Tahun 2012 yaitusebesar 51,4 kategori sedang sedangkan rata-rata nilai postes sikap siswa SMAN Kota Sum bawa Besar tahun 2012 sebesar 67,2 kategori baik.

Persentase peningkatan antara rata-rata nilai pretes dan rata-rata nilai pos tes pada kelas eksperimen sebesar $38,1 \%$ sedangkan persentasi peningkatan an tara rata-rata nilai pretes dan rata-rata nilai postes kelas kontrol sebesar 30,7\%. Untuk menggambarkan data lebih jelas disajikan dalam Gambar 4.14.

Berdasarkan nilai setiap indikator sikap yang terdapat dalam instrument tes sikap yaitu A4 (mengorganisasi), dan A5 (menjadikan pola hidup) dari hasil nilai rata-rata nilai sikap yang didapatkan pada kelas eksperimen dan kelas kontrol maka didapatkan nilai rata-rata seperti tertera pada Tabel 4.10 dan 4.11

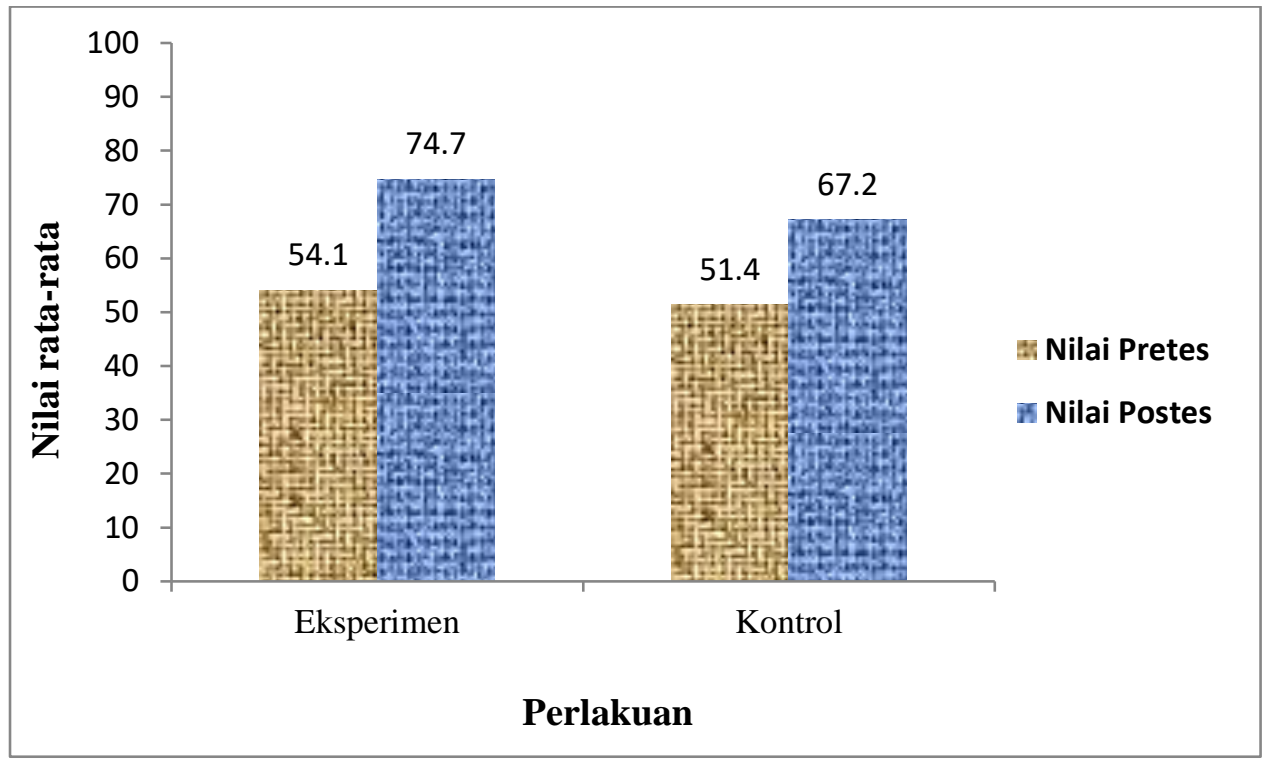

Gambar 4.14 Rata-rata Nilai Sikap Siswa pada Kelas Eksperimen dan Kelas Kontrol SMAN Kota Sumbawa Besar (Sumber: Lampiran 18) 
Tabel 4.10 Rata-rata Sikap Siswa SMAN Kota Sumbawa Besar pada Tiga Kelas Eksperimen

\begin{tabular}{ccccccc}
\hline No & Indikator Sikap & $\begin{array}{c}\text { Rata-rata } \\
\text { Pretes }\end{array}$ & Kategori & $\begin{array}{c}\text { Rata-rata } \\
\text { Postes }\end{array}$ & Kategori & Persentase \\
\hline 1 & A4 & 54,2 & Sedang & 79,9 & Baik & 47,4 \\
\hline 2 & A5 & 51,3 & Sedang & 69,6 & Baik & 35,7 \\
\hline
\end{tabular}

Sumber: Lampiran 19

Ket: A4 (mengorganisasikan) \& A5 ( menjadikan pola hidup)

Tabel 4.11 Rata-rata Sikap Siswa SMAN Kota Sumbawa Besar pada Tiga Kelas Kontrol

\begin{tabular}{ccccccc}
\hline No & Indikator Sikap & Rata-rata Pretes & Kategori & $\begin{array}{c}\text { Rata-rata } \\
\text { Postes }\end{array}$ & Kategori & Persentase \\
\hline 1 & A4 & 52,8 & Sedang & 65,8 & Baik & 24,6 \\
\hline 2 & A5 & 53,8 & Sedang & 70,2 & Baik & 30,5 \\
\hline
\end{tabular}

Sumber Lampiran 20

Ket: A4 (mengorganisasikan)

A5 ( menjadikan pola hidup)

Berdasarkan Tabel 4.10 dan 4.11 dapat dijelaskan bahwa terjadi kenaikan rerata skor pretes dan postes. Kenaikan skor sikap tertinggi pada kelas eksperimen saat pretes yaitu indikator A4 sebesar 54,2 kategori sedang dan postes sebesar 79,9 kategori baik artinya siswa mampu menjawab dengan baik terkait langkalangka yang dilakukan jika kita sebagai pemegang kebijakan dalam mengatasi masalah kerusakan lingkungan. Jawaban indikator tersebut yaitu mengadakan sosialisasi kepada masyarakat akan pentingnya menjaga lingkungan, selain itu sebagai pemegang kebijakan hendaknya dapat memberikan sangsi yang tegas kepada pelaku pengrusakan lingkungan jika terjadi kerusakan lingkungan oleh oknom-oknum yang tidak bertanggung jawab dengan lingkungan. Memberikan sangsi yang tegas kepada pelaku yang melakukan perusakan terhadap lingkungan, menertibkan Undang-Undang tentang eksploetasi lingkungan seperti, Deporestation, pengelolaan sampah yang tidak terarah, Eksploetasi SDA (Sumber Daya Alam), dan Ilegal Logging, menjalin hubungan kerjasama antara sektor formal (instansi pendidikan) maupun sektor informal (masyarakat) dalam usaha 
mengatasi kerusakan lingkungan, menciptakan program-program seperti konservasi lingkungan misalnya konsservasi SDAH (Sumber Daya Alam Hayati), konservasi tanah, hutan, dan konservasi iar, maupun daur ulang limbah (misalnya daur ulang sampah dengan konsep 6M), sebagai wujud dari peduli lingkungan

Persentase peningkatan antara rata-rata nilai pretes dan postes tertinggi kelas eksperimen yaitu indikator A4 sebesar 47,4\%. Sedangkan pada kelas kontrol nilai rata-rata sikap tertinggi pada indikator A5 dengan nilai pretes sebesar 53,8 kategori sedang dan postes 70,2 kategori baik dengan presentase peningakatan sebesar $40 \%$. Nilai rata-rata terendah pada kelas eksperimen terdapat pada saat pretes indikator A5 sebesar 51,3 kategori sedang dan postes 69,6 kategori baik persentase peningkatan sebesar $35,7 \%$ Sedangkan nilai terendah pada kelas kontrol terdapat pada saat pretes indikator A4 sebesar 52,8 sedang dan nilai postes 65,8 kategori baik persentase peningkatan sebesar $24,6 \%$. Rata-rata nilai rata-rata sikap pretes dan postes pada kelas kontrol beserta kategorinya dapat dijelaskan pada Gambar 4.15 dan 4.16

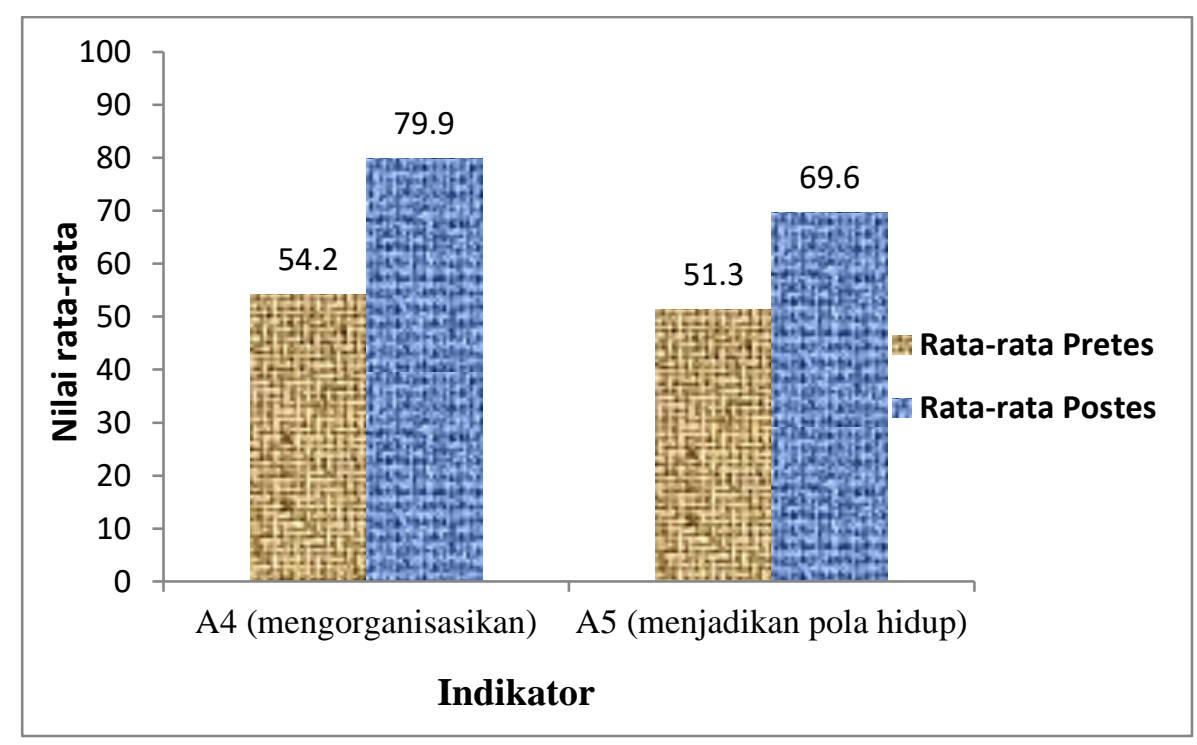

Gambar 4.15 Rata-rata Nilai Setiap Aspek Sikap SiswaSMAN Kota Sumbawa Besar pada Kelas Eksperimen (Sumber: Lampiran 19) 


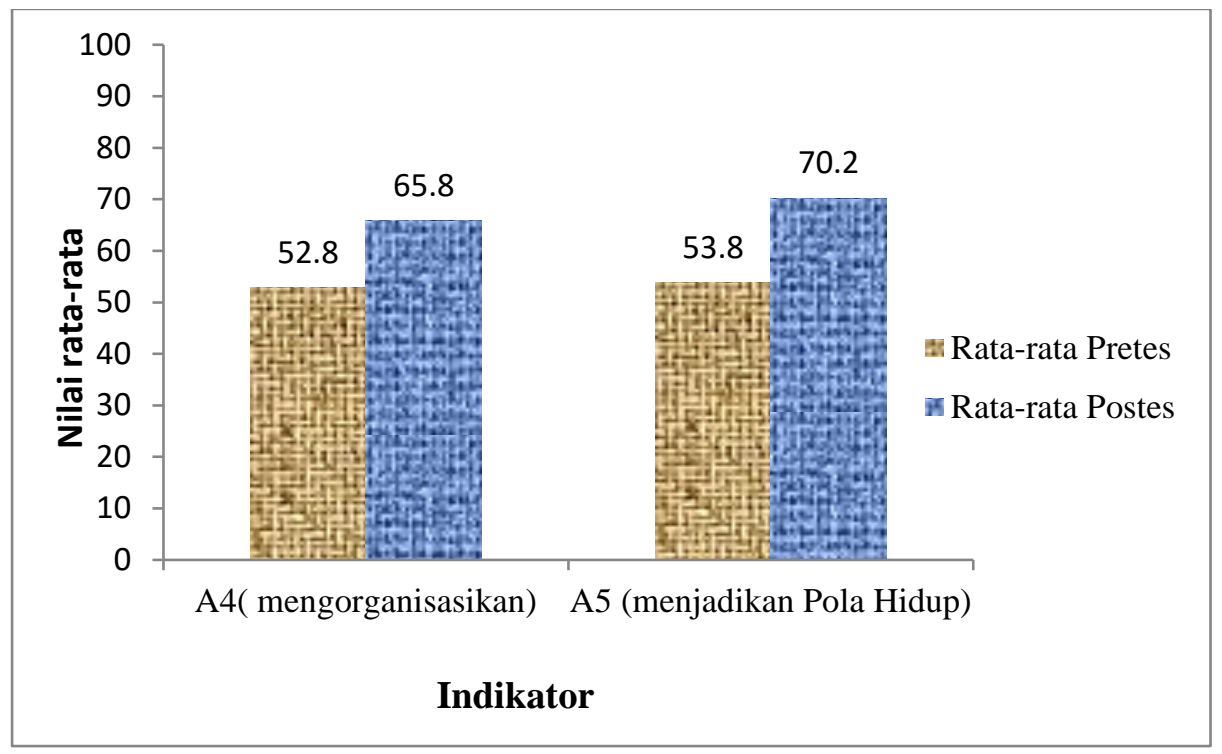

Gambar 4.16 Rata-rata Nilai Setiap Aspek Sikap Siswa SMAN Kota Sumbawa Besar pada Kelas Kontrol (Sumber: Lampiran 20)

\section{Keterampilan Siswa dalam Pengelolaan Sampah SMAN Kota Sumbawa Besar}

Rata-rata nilai keterampilan siswa dalam pengelolaan sampah di SMAN Kota Sumbawa Besar tahun 2012 tertera pada Tabel 4.12

Tabel 4.12 Rata-rata Keterampilan Siswa dalam Pengelolaan Sampah Tiga Sekolah SMAN Kota Sumbawa Besar

\begin{tabular}{c|ccccc}
\hline \multirow{2}{*}{ Kelas Eksperimen } & \multicolumn{4}{|c}{ Kategori } \\
\cline { 2 - 5 } & Sangat Kurang & Kurang & Sedang & Baik & Sangat Baik \\
\hline Sekolah 1 & $0-40$ & $41-54$ & $55-65$ & $66-83$ & \\
\hline Sekolah 2 & \multicolumn{4}{c}{77,9} \\
\hline Sekolah 3 & 75 \\
\hline Rata-rata Nilai & \multicolumn{5}{c}{70,9} \\
\hline Sumber: Lampiran 21
\end{tabular}

Sumber: Lampiran 21 
Berdasarkan Tabel 4.12 sesuai Penilain Acuan Patokan (PAP) yang digunakan di Universitas Negeri Malang dapat dijelaskan bahwa rata-rata nilai kelompok keterampilan siswa dalam pengelolaan sampah di SMAN Kota Sumbawa Besar tahun 2012 yaitu kelas sekolah 1 didapatkan nilai rata-rata kelompok keterampilan siswa sebesar 77,9 dengan kategori baik, sekolah 2 nilai rata-rata keterampilan kelompok sebesar 75,0 kategori baik dan nilai rata-rata keterampilan kelompok siswa sekolah 3 sebesar 70,9 dengan kategori baik.

Total nilai rata-rata keseluruhan keterampilan kelompok di SMAN Kota Sumbawa Besar tahun 2012 sebasar 74,6 kategori baik. Dalam penelitian ini pada kelas kontrol tidak menunjukan aktivitas siswa dalam pemberian pembelajaran proyek seperti keterampilan dalam pengelolaan sampah sehingga dapat disimpulkan bahwa keterampilan siswa yang diajarkan di kelas eksperimen memiliki pengetahuan yang berbeda dengan kelas kontrol. Hal ini bisa dibuktikan dari aktivitas siswa pada kelas kontrol yang tidak melakukan kegiatan keterampilan di lapangan atau pemberian proyek lainya kepada siswa.

\section{B. Uji Prasarat dan Uji Hipotesis}

\section{Uji Prasarat}

\section{a. Uji Normalitas Data Kemampuan Berpikir Kritis, Pengetahuan, Sikap}

Berdasarkan hasil uji normalitas data kemampuan berpikir kritis dengan menggunakan Kolmogorov-Smirnov. Data dikatakan terdistribusi normal bila nilai taraf signifikansi lebih besar dari 0,005. Taraf signifikansi hasil uji normalitas pada kemampuan berpikir kritis berdasarkan hasil uji One-Simple KolmogorovSmirnov Test pada kemampuan berpikir kritis awal didapatkan $(\mathrm{p}=0,053)$, dapat disimpulkan bahwa data awal pengetahuan tidak menyimpang dari distribusi 
normal artinya hepotesis penelitian diterima,. Hasil uji One-Simple KolmogorovSmirnov Test pada data akhir kemampuan berpikir kritis akhir didapatkan $(\mathrm{p}=0,010)$, sehingga dapat disimpulkan bahwa data postes kemampuan berpikir kriris menyebar normal.

Berdasarkan hasil uji normalitas pengetahuan dengan menggunakan Kolmogorov-Smirnov. Data dikatakan terdistribusi normal bila nilai taraf signifikansi lebih besar dari 0,005. Taraf signifikansi hasil uji normalitas pada pengetahuan berdasarkan hasil uji One-Simple Kolmogorov-Smirnov Test pada pengetahuan awal didapatkan $(\mathrm{p}=0,052)$, sehingga dapat disimpulkan bahwa data pretes pengetahuan menyebar normal artinya hipotesis penelitian diteriam, bahwa data berasal dari data yang berdistribusi normal. Hasil uji One-Simple Kolmogorov-Smirnov Test pada data pengetahuan akhir didapatkan $(\mathrm{p}=0,052)$, sehingga dapat disimpulkan bahwa data postes pengetahuan siswa menyebar normal.

Berdasarkan hasil uji normalitas sikap dengan menggunakan KolmogorovSmirnov. Data dikatakan terdistribusi normal bila nilai taraf signifikansi lebih besar dari 0,005. Taraf signifikansi hasil uji normalitas sikap berdasarkan hasil uji One-Simple Kolmogorov-Smirnov Test pada sikap awal didapatkan $(\mathrm{p}=0,052)$, sehingga dapat disimpulkan bahwa data pretes sikap tidak menyimpang dari distribusi normal artinya hepotesis penelitian diterima, bahwa data berasal dari data yang berdistribusi normal. Hasil uji One-Simple Kolmogorov-Smirnov Test pada data sikap akhir didapatkan $(\mathrm{p}=0,052)$, sehingga dapat disimpulkan bahwa data akhir sikap siswa menyebar normal. Ringkasan hasil uji normalitas data 
kemampuan berpikir kritis awal dan akhir, data pengetahuan awal dan akhir, data sikap awal dan akhir terdapat (lampiran 23)

\section{b. Uji Homogenitas}

Uji Homogenitas dilakukan dengan uji Leven's dilakukan terhadap pretes dan postes variabel terikat terkoreksi. Berdasarkan hasil perhitungan diperoleh sig.(p-level) $>0,05)$. Hal ini menunjukan varian tidak berbeda. Artinya semua data pada variabel kemampuan berpikir kritis, pengetahuan dan sikap terdistribusi homogen.

Berdasarkan hasil uji homogenitas menggunakan Uji Levene's data dikatakan homogen bila nilai taraf signifikansi lebih besar dari 0,05. Taraf signifikansi hasil uji Levene's pada tes akhir kemampuan berpikir kritis didapatkan $(\mathrm{p}=0.052)$. Sehingga dapat disimpulkan bahwa ragam galat pada variable terikat postes kemampuan berpikir kritis menyebar secara homogen pada setiap perlakuan.

Hasil uji Levene's pada tes akhir pengetahuan siswa didapatkan $(\mathrm{p}=0,053)$ sehingga dapat disimpulkan bahwa ragam galat pada variable terikat postes pe ngetahuan siswa menyebar secara homogen pada setiap tingkat perlakuan.

Hasil uji Levene's pada tes akhir sikap siswa didapatkan $(\mathrm{p}=0,077)$, sehingga dapat disimpulkan bahwa ragam galat pada variable terikat postes sikap siswa menyebar secara homogen pada setiap tingkat perlakuan. Untuk melihat keseluruhan hasil uji homogenitas postes kemampuan berpikir kritis, postes pengetahuan, postes sikap terdapat pada (lampiran 23) 


\section{Uji Hipotesis}

a. Pengaruh Pembelajaran Berbasis Proyek berbantuan Media DVD 6M Terhadap Kemampuan Berpikir Kritis dalam Pengelolaan Lingkungan

Berdasarkan hasil uji hipotesis dengan Anakova menunjukan adanya pengaruh yang signifikan strategi pembelajaran berbasis proyek berbantuan media DVD $6 M$ terhadap kemampuan berpikir kritis $(\mathrm{p}=0,004)$, Arinya hipotesis nol ditolak dan hipotesis penelitian diterima menyatakan ada perbedaan pengaruh strategi pembelajaran berbasis proyek berbantuan media DVD $6 M$ terhadap kemampuan berpikir kritis dibanding pembelajaran yang kelas konvensional

Berdasarkan uji anakova dapat disimpulkan bahwa pembelajaran dengan strategi pembelajaran berbasis proyek berbantuan media $D V D 6 M$ berpengaruh terhadap kemampuan berpikir kritis. Siswa yang dibelajarkan dengan strategi pembelajaran berbasis proyek berbantuan media DVD $6 M$ menunjukan hasil kemampuan berpikir kritis yang lebih baik daripada siswa yang diberi pembelajaran pembelajaran konvensional. Ringkasan hasil uji anakova pada postes kemampuan berpikir kritis disajikan pada Tabel 4.13

Tabel 4.13 Ringkasan Uji Anakova Pengaruh Strategi Pembelajaran Berbasis Proyek berbantuan media DVD 6M Terhadap Kemampuan Berpikir Kritis Siswa SMAN Kota Sumbawa

\begin{tabular}{lcrrrr}
\hline $\begin{array}{c}\text { Sumber } \\
\text { Keragaman }\end{array}$ & $\begin{array}{c}\text { Jumlah } \\
\text { Kuadrat }\end{array}$ & $\begin{array}{c}\text { Derajat } \\
\text { bebas }\end{array}$ & $\begin{array}{c}\text { Rerata } \\
\text { Kuadrat }\end{array}$ & \multicolumn{1}{c}{ F } & Signifikan \\
\hline Kemampuan berpikirits Awal & 439,487 & 1 & 439,487 & 13,907 &, 000 \\
\hline Kelas & 267,702 & 1 & 267,702 & 8,471 &, 004 \\
\hline Kesalahan & 5719,939 & 181 & 31,602 & & \\
\hline Total & 6474,435 & 183 & & & \\
\hline Sumber: Lampiran 23 & & & &
\end{tabular}

Sumber: Lampiran 23 
Tabel 4. 14 Hasil Uji LSD Notation Kemampuan Berpikir Kritis

\begin{tabular}{lcccccc}
\hline \multicolumn{1}{c}{ KELAS } & XKBK & YKBK & SELISIH & KBKCOR & \multicolumn{2}{c}{ LSD notation } \\
\hline Kontrol & 46,13 & 63,49 & 17,36 & 63,59 & a & \\
\hline Eksperimen & 47,30 & 66,11 & 18,81 & 66,01 & $\mathrm{~b}$ \\
\hline
\end{tabular}

Ket: XKBK : Nilai kemampuan berpikir kritis awal (pretes)

Y KBK : Nilai kemampuan berpikir kritis akhir (postes)

KBKCOR : Nilai kemampuan berpikir kritis terkoreksi

LSD notation : Notasi LSD

\section{b. Pengaruh Strategi Pembelajaran Berbasis Proyek Berbantuan Media DVD 6M Terhadap Pengetahuan Siswa dalam Pengelolaan Lingkungan}

Hasil uji hipotesis dengan Anakova menunjukan adanya pengaruh yang signifikan strategi pembelajaran berbasis proyek berbantuan media DVD $6 M$ terhadap pengetahuan $(\mathrm{p}=0,000)$, Arinya hipotesis nol ditolak dan hipotesis penelitian diterima menyatakan ada perbedaan pengaruh strategi pembelajaran berbasis proyek berbantuan media $D V D 6 M$ terhadap pengetahuan dibanding pembelajaran yang kelas konvensional

Berdasarkan hasil analisis dapat disimpulkan bahwa pembelajaran dengan strategi pembelajaran berbasis proyek berbantuan media $D V D 6 M$ berpengaruh terhadap pengetahuan. Siswa yang diberikan pembelajaran berbasis proyek berbantuan media $D V D 6 M$ menunjukan hasil pengetahuan yang lebih baik daripada siswa yang diberi pembelajaran dengan pembelajaran konvensional. Hasil uji hipotesis pengaruh strategi pembelajaran terhadap pengetahuan disajikan dalam Tabel 4.15

Tabel 4.15 Ringkasan Uji Anakova Pengaruh Strategi Pembelajaran Berbasis Proyek Berbantuan DVD 6M Terhadap Pengetahuan Siswa SMAN Kota Sumbawa

\begin{tabular}{lrrrrr}
\hline $\begin{array}{c}\text { Sumber } \\
\text { Keragaman }\end{array}$ & $\begin{array}{c}\text { Jumlah } \\
\text { Kuadrat }\end{array}$ & \multicolumn{1}{c}{$\begin{array}{c}\text { Derajat } \\
\text { Bebas }\end{array}$} & $\begin{array}{c}\text { Rerata } \\
\text { Kuadrat }\end{array}$ & \multicolumn{1}{c}{ F } & \multicolumn{1}{c}{ Signifikansi } \\
\hline Pengetahuan awal & 629,300 & 1 & 629,300 & 19,969 &, 000 \\
\hline Kelas & 970,745 & 1 & 970,745 & 30,804 &, 000 \\
\hline Kesalahan & 5703,959 & 181 & 31,514 & & \\
\hline Total & 7551,570 & 183 & & & \\
\hline Sumber: Lampiran 23 & & & & &
\end{tabular}


Tabel 4. 16 Hasil Uji LSD Notation Pengetahuan

\begin{tabular}{lccccc}
\hline \multicolumn{1}{c}{ KELAS } & XPENG & YPENG & SELISIH & PENGCOR & LSD notation \\
\hline Kontrol & 47,18 & 65,94 & 18,76 & 66,20 & $\mathrm{a}$ \\
\hline Eksperimen & 50,45 & 71,09 & 20,64 & 70,84 & $\mathrm{~b}$ \\
\hline
\end{tabular}

Ket: XPENG : Nilai pengetahuan awal (pretes) PENGCOR: Nilai Pengetahuan Terkoreksi Y PENG : Nilai pengetahuan akhir (postes) LSD notation : Notasi LSD

c. Pengaruh Strategi Pembelajaran Berbasis Proyek Berbantuan Media DVD 6M Terhadap Sikap Siswa dalam Pengelolaan Lingkungan

Hasil uji hipotesis dengan Anakova menunjukan adanya pengaruh yang signifikan strategi pembelajaran berbasis proyek berbantuan media DVD $6 M$ terhadap sikap, $(\mathrm{p}=0,000)$. Arinya hipotesis nol ditolak dan hipotesiss penelitian diterima bahwa ada perbedaan pengaruh strategi pembelajaran berbasis proyek berbantuan media $D V D 6 M$ terhadap sikap siswa dibanding pembelajaran yang kelas konvensional

Berasarkan hasil analisis dapat disimpulkan pembelajaran dengan startegi pembelajaran berbasis proyek berbantuan media $D V D 6 M$ berpengaruh terhadap sikap siswa. Siswa yang diberikan pembelajaran dengan strategi pembelajaran berbasis proyek bantuan media DVD $6 M$ menunjukan hasil sikap yang lebih baik daripada siswa yang diberi pembelajaran dengan pembelajaran konvensional. Hasil uji hipotesis pengaruh strategi pembelajaran terhadap sikap disajikan dalam Tabel 4.17

Tabel 4.17 Ringkasan Uji Ancova Pengaruh Strategi Pembelajaran Berbasis Proyek Berbantuan Media DVD 6M Terhadap Sikap Siswa SMAN Kota Sumbawa

\begin{tabular}{lcrrrr}
\hline $\begin{array}{c}\text { Sumber } \\
\text { Keragaman }\end{array}$ & $\begin{array}{c}\text { Jumlah } \\
\text { Kuadrat }\end{array}$ & \multicolumn{1}{c}{$\begin{array}{c}\text { Derajat } \\
\text { Bebas }\end{array}$} & $\begin{array}{c}\text { Rerata } \\
\text { kuadrat }\end{array}$ & \multicolumn{1}{c}{ F } & Signifikansi \\
\hline Sikap awal & 163,575 & 1 & 163,575 & 3,985 &, 047 \\
\hline Kelas & 2385,139 & 1 & 2385,139 & 58,109 &, 000 \\
\hline Kesalahan & 7429,351 & 181 & 41,046 & & \\
\hline Total & 10188,995 & 183 & & & \\
\hline
\end{tabular}

Sumber:Lampiran 23 
Tabel 4. 18 Hasil Uji LSD Notation Sikap

\begin{tabular}{lcccccc}
\hline \multicolumn{1}{c}{ KELAS } & XSIKAP & YSIKAP & SELISIH & SIKAPCOR & \multicolumn{2}{c}{ LSD Notation } \\
\hline Kontrol & 51,39 & 67,17 & 15,78 & 67,29 & $\mathrm{a}$ & \\
\hline Eksperimen & 54,26 & 74,68 & 20,43 & 74,56 & & $\mathrm{~b}$ \\
\hline
\end{tabular}

Ket: XSIKAP : Nilai sikap awal (pretes)

Y SIKAP : Nilai sikap akhir (postes)

SIKAPCOR : nilai sikap terkoreksi

LSD notation : Notasi LSD

d. Bagaimana Keterampilan Siswa dalam Pengelolaan Sampah melalui Strategi Pembelajaran Berbasis Proyek Berbantuan Media DVD 6M di SMAN Kota Sumbawa

Berdasarkan hasil penilaian produk sesuai Penilain Acuan Patokan (PAP) yang digunakan di Universitas Negeri Malang dapat dijelaskan bahwa rata-rata nilai kelompok keterampilan siswa dalam pengelolaan sampah SMAN Kota Sumbawa Besar tahun 2012 dapat dijelaskan, pada kelas sekolah I didapatkan nilai rata-rata kelompok keterampilan siswa sebesar 77.9 dengan kategori baik,kelas sekolah 2 nilai rata-rata keterampilan kelompok sebesar 75.0 kategori baik dan nilai rata-rata keterampilan kelompok siswa kelas sekolah 3 sebesar 70.9 dengan kategori baik. Ringkasan diskripsi nilai data untuk keterampilan siswa dalam pengelolaan sampah di SMAN Kota Sumbawa Besar terdapat pada Tabel 4.19

Tabel 4.19 Hasil Keterampilan Siswa dalam Pengelolaan Sampah

\begin{tabular}{|c|c|c|c|c|c|}
\hline & $\mathrm{N}$ & Minimum & Maximum & Mean & Std. Deviation \\
\hline Proyek & 94 & 65,00 & 85,00 & 74,6 & 5,01912 \\
\hline Valid N (listwise) & 94 & & & & \\
\hline
\end{tabular}

Berdasarkan Tabel 4.19 dapat dijalaskan bahwa total nilai rata-rata keseluruhan keterampilan proyek di SMAN Kota Sumbawa Besar tahun 2012 sebasar 74.6. Sedangkan pada kelas kontrol pelaksanaan penerapan strategi pembelajaran berbasis proyek berbantuan media $D V D 6 M$ tidak diterapkan oleh guru bidang studi sehingga dengan demikian dapat disimpulkan bahwa penerapan 
strategi pembelajaran berbasis proyek berbantuan media $D V D 6 M$ antara kelas eksperimen memiliki perbedaan. Hal ini dapat dimakani pada kelas kontrol karena tidak perna menerapakan pembelajaran tersebut maka sebagai nilai perbandingan dianggap nol dan pada kelas eksperimen memiliki nilai rata-rata kelompok sebesar 74.6 dengan tingkat kategori baik. 


\section{BAB V}

\section{PEMBAHASAN}

\section{A. Kemampuan Berpikir Kritis Siswa SMAN Kota Sumbawa Besar dalam Pengelolaan Lingkungan}

Berdasarkan hasil penelitian dapat dijelaskan bahwa rata-rata nilai kemampuan berpikir kritis antara siswa pada kelas eksperimen cenderung lebih besar daripada kelas kontrol. Hal ini dapat dilihat dari persentase peningkatan antara rata-rata nilai pretes dan postes pada kelas eksperimen dan kontrol. Persentase pada kelas eksperimen sebesar 40,3\% dan kelas kontrol sebesar 37,4\%. Artinya dapat disimpulkan bahwa pemberian strategi pembelajaran berbasis proyek berbantuan media $D V D 6 M$ dapat meningkatkan nilai kemampuan berpikir kritis dibandingkan dengan kelas yang diberi pembelajaran konvensional.

Berdasarkan nilai rata-rata setiap indikator kemampuan berpikir kritis dari hasil penilitian dapat dijelaskan bahwa peserta didik yang belajar dengan strategi pembelajaran berbasis proyek berbantuan media DVD $6 M$ mengalami kenaikan rata-rata nilai pretes dan postes. Nilai rata-rata tertinggi kelas eksperimen yaitu indikator sebab akibat dengan nilai pretes 47,8 tergolong kategori sedang, dan nilai rata-rata postes sebesar 73,2 tergolong kategori baik. Artinya siswa yang dibelajarkan strategi pembelajaran berbasis proyek berbantuan media DVD $6 M$ mampu menjawab dengan baik faktor-faktor penyebab terjadinya kerusakan lingkungan. Jawaban yang dimaksud penyebab terjadinya pencemaran lingkungan 
adalah faktor pencemaran yang terjadi secara alamia misalnya gunung meletus, gempa bumi, erosi dan lain-lain. Pencemaran lingkungan secara buatan atau oleh ulah perbuatan manusia. seperti tanah longsor, sistem pengelolaan sampah yang tidak terkontrol, banjir, eksploetasi SDA, dan lain-lain.

Peningkatan tertinggi pada kelas eksperimen terdapat pada indikator menganalisis yaitu sebesar 53,7\%, sehingga dapat dijelaskan bahwa melalui skenario pembelajaran berbasis proyek pada pelakasanaan proyek siswa dalam mengkomunikasikan gagasan atau temuan dengan anggota kelompoknya dilapangan mampu menganalisis dengan baik permasalahan yang berkaitan dengan mempridiksikan dampak yang akan muncul jika permasalahan kerusakan lingkungan tidak segera ditangani misalnya, terjadinya ketidak seimbangan kebersihan didalam lingkungan tempat tinggal, dapat menimbulkan penyakit, akan menimbulkan berbagai jenis kerusakan lingkungan, bertambahnya emisi gas $\mathrm{CO}_{2}$ di udara sekitar, dan lingkungan menjadi tercemar.

Peningkatan terendah terdapat pada indikator mengelompokan yakni sebesar 29,5\%. Dapat dijelaskan bahwa melalui skenario pembelajaran berbasis proyek pada perencanaan proyek siswa belum efektif melakukan diskusi secara berkelompok sehingga tidak maksimal dalam mengelompokan jenis-jenis pencemaran limbah yang dapat menimpa masyarakat sekitar. Jawaban yang dismaksud adalah Pencemaran air meliputi pencemaran limbah industri, pencemaran air laut, pencemaran pertanian, Pencemaran tanah seperti polutan utama pencemaran tanah berupa limbah padat, meliputi, kotoran, sampah, lumpur serta produk pertanian, tambang dan industri yang sudah tidak berguna. Selanjutnya penyebab utama pencemaran udara, yaitu polutan alami badai pasir, 
kebakaran hutan, dan letusan gunung merapi,dan residu bahan bakar fosil dari asap kendaraan maupun industri.

Hasil uraian diatas dapat disimpulakan sebagai temuan dalam penelitian ini bahwa peserta didik yang banyak terlibat dalam pembelajaran berbasis proyek berbantuan media $D V D 6 M$ memiliki rata-rata nilai kemampuan berpikir kritis lebih tinggi dibandingkan dengan peserta didik yang mengikuti pembelajaran konvensional.

Temuan dalam penelitian ini didukung oleh hasil penelitian Mahanal (2009) terkait penerapan pembelajaran lingkungan hidup berbasis proyek untuk memberdayakan kemampuan berpikir kritis, penguasaan konsep, dan sikap siswa. Hasil penelitian menunjukan pembelajaran lingkungan hidup berbasis proyek dapat memberdayakan kemampuan berpikir kritis siswa di SMAN 9 Malang. Hasil temuan diatas didukung oleh penyataan Ibrohim 2000 dalam Hotima, 2011) menyatakan, kemampuan berpikir kritis peserta didik akan mengalami peningkatan seiring dengan strategi pembelajaran yang digunakan, oleh karena itu pembelajaran harus memberdayakan kemampuan berpikir kritis

Glaser (2009) mendifinisikan berpikir kritis sebagai: (1) suatu sikap mau berpikir mendalam tentang masalah-masalah dan hal yang berbeda dalam jangkauan pengalaman seseorang, (2) pengetahuan tentang metode-metode pemeriksaan dan penalaran yang logis, (3) semacam suatu keterampilan untuk menerapkan metode-motede tersebut. Berpikir kritis menuntut sutau upaya keras untuk memeriksa setiap keyakinan atau pengetahuan asumtif berdasarkan bukti pendukungnya dan kesimpulan-kesimpulan lanjutan yang diakibatkannya. 
Pendapat lain menurut Fisher \& Scriven, (1997) berpikir kritis adalah interpretasi dan evaluasi yang terampil dan aktif terhadap observasi dan komunikasi, informasi dan argumentasi. Pendapat senada manurut Duron (2006 dalam Ruchima, 2011) kemampuan berpikir kritis adalah kemampuan untuk membuat analisis dan melakukan evaluasi terhadap data atau informasi. Penner (1995 dan lowson, 2000) bahwa kemampuan berpikir kritis dapat dikembangkan, tetapi tidak dapat dilatihkan sekaligus. Mengembangkan kemampuan berpikir kritis memerlukan waktu yang cukup.

Kegiatan pembelajaran yang direncanakan dan dilaksanakan dengan baik untuk mengembangkan kemampuan berpikir merupakan faktor yang sangat penting. Sehingga dapat disimpulkan bahwa partisipasi aktif peserta didik dalam pembelajaran akan meningkatkan hasil belajarnya.

\section{B. Pengetahuan Siswa SMAN Kota Sumbawa Besar dalam Pengelolaan Lingkungan}

Berdasarkan hasil tes pengetahuan siswa di SMAN Kota Sumbawa Besar dapat dijelaskan rata-rata nilai pretes dan postes pengetahuan siswa pada kelas eksperimen cendrung lebih tinggi daripada kelas kontrol. Peningkatan pengetahuan pada kelas eksperimen yaitu sebesar $41,5 \%$, sedangkan pada kelas kontrol rata-rata persentse peningkatan sebesar 39,6\%. Dari hasil persentase peningkatan antara kelas eksperimen dan kelas kontrol dapat diartikan bahwa pemberian strategi pembelajaran berbasis proyek berbantuan media $D V D 6 M$ mampu meningkatkan pengetahuan siswa dalam pengelolaan sampah di SMAN Kota Sumbawa Besar dibanding dengan kelas yang menggunakan pembelajaran konvensional. 
Berdasarkan hasil penelitian nilai rata-rata setiap indikator pengetahuan cenderung mengalami kenaikan rata-rata nilai pretes dan postes. Rata-rata nilai pengetahuan tertinggi pada kelas eksperimen yaitu indikator memahami (C2) dengan nilai pretes yaitu sebesar 61,5 kategori baik, dan nilai postes sebesar 81,0 kategori sangat baik. Artinya siswa dapat memahami dengan baik mengenai bahan-bahan polutan yang terdapat dijalan raya, seperti Carbon Monoksida (CO), Hidrogen Oksida (HO), Hidrokarbon (HC), Karbon diaoksida (CO2), Bahan bakar posil, dan lain lain kesemua bahan polutan diatas dapat menyebabkan kerusakan lingkungan dan salah satu pemicu kerusakan lingkungan khususnya dijalan raya adalah sistem pengelolaan sampah yang tidak terkontrol dengan baik.

Rata-rata nilai terendah pada indikator menganalisis (C6) rata-rata nilai pretes sebesar 41,9 kategori sedang, dan rata-rata nilai postes sebesar 66,9 kategori baik, artinya siswa belum maksimal menganalisis dampak negatif dari prilaku tidak rama lingkungan. Persentase peningkatan tertinggi terdapat pada indikator mengevaluasi (C6) sebesar 59,7\%. Melalui skenario pembelajaran berbasis proyek pada tahap presentasi hasil proyek siswa mampu menciptakan pemikiran baru sebagai proses belajar mengajar dan tindak lanjut dalam pembelajaran siswa mampu menciptakan pemikiran dengan baik terkait dampak negatif yang akan muncul jika tidak segera ditangani dalam mengatasi permasalahan kerusakan lingkungan. Persentase terendah pada indikator menganalisis (C4) sebesar 30,5\%. Melalui Skenario pembelajaran berbasis proyek siswa dalam tahap mengambil kesimpulan belum maksimal dalam menganalisis temuannya dilingkungan keluarga apa yang menyebabkan prilaku tidak rama lingkungan itu dapat terjadi 
Berdasarkan temuan dalam penelitian ini didukung oleh hasil penelitian Setiowati (2011) tentang pengembangan modul mutimedia pengelolaan sampah berwawasan sain, teknologi, dan masyarakat (STM) sebagai upaya untuk meningkatkan pengetahuan, sikap, dan prilaku peserta didik. Hasil penelitian menunjukan pembelajaran modul multimedia pengelolaan sampah sangat efektif meningkatkan pengetahuan peserta didik dengan keterlaksanaan tergolong sangat baik. Program pendidikan tentang pengelolan sampah disekolah memiliki dampak positif bagi pengetahuan peserta didik khususnya tentang isu-isu sampah.

Temuan penelitian lain sebagai pendukung penelitian ini adalah hasil penelitian Al Muhdhar (2003) meneliti tentang keterkaitan faktor sosial, ekonomi, pengetahuan, dan sikap dengan manifestasi prilaku ibu-ibu rumah tangga dalam pengelolaan sampah di Kota Surabaya. Hasil penelitian dengan metode stepwise menunjukan bahwa pengetahuan ibu-ibu rumah tangga di tentukan oleh faktor kunci tingkat pendidikan ibu-ibu rumah tangga dan jumlah media imformasi yang dimilikinya.

Hasil penelitian penelitian diatas ini didukung pernyataan Al Muhdhar (1999) menyatakan bahwa makin tinggi tingkat pendidikan ibu-ibu rumah tangga, makin tinggi pula pengetahuan dalam pengelolaan sampah rumah tangga. Selain tingkat pendidikan yang berpengaruh terhadap pengetahuan ibu-ibu rumah tangga yaitu jumlah informasi yang dimiliki. Semakin banyak media informasi yang dimiliki oleh ibu-ibu rumah tangga semakin tinggi pula pengetahuan dalam pengelolaan sampah. 


\section{Sikap Siswa SMAN Kota Sumbawa Besar dalam Pengelolaan Lingkungan}

Berdasarkan hasil penelitian dapat dijelaskan bahwa rata-rata nilai pretes dan postes sikap siswa SMAN Kota Sumbawa Besar pada kelas eksperimen cendrung lebih tinggi dibandingkan kelas kontrol. Persentase peningkatan antara rata-rata nilai pretes dan rata-rata nilai postes pada kelas eksperimen yaitu sebesar $38,1 \%$, sedangkan persentasi peningkatan antara rata-rata nilai pretes dan rata-rata nilai postes kelas kontrol yaitu sebesar 30,7 \%. Dari hasil persentase peningkatan antara kelas eksperimen dan kelas kontrol dapat diartikan bahwa dengan pemberian strategi pembelajaran berbasis proyek berbantuan media $D V D 6 M$ mampu meningkatkan sikap siswa dalam pengelolaan sampah di SMAN Kota Sumbawa Besar.

Peningkatan rata-rata nilai pretes dan postes tertinggi pada masing-masing indikator sikap kelas eksperimen yaitu pada indkator A4 (mengorganisasikan) sebesar 47,4\%. Melalui skenario pembelajaran berbasis proyek dengan melakukan kerjasama dan mengembangkan pemikiran dan mengorganisasikan pemikiran yang bijak sebagai bentuk sikap yang baik terhadap lingkungan siswa mampu mengorganisasikan Stakeholder yang akan dilibatkan dalam mengatasi kerusakan lingkungan, misalnya anggota keluarga, individu masing-masing, instansi terkait (dinas kebersihan, pemerintah daerah), lingkungan sekolah (murid, guru kepalah sekolah) dan masyarakat. Persentase peningkatan terendah pada indikator A5 ( mengorganisasi) yaitu sebesar $35,7 \%$.

Hasil uraian diatas didukung hasil penelitian Al Muhdhar (2003) bahwa faktor kunci yang menentukan sikap ibu-ibu rumah tangga dalam pengelolaan 
sampah adalah jumlah media informasi yang dimiliki oleh ibu-ibu rumah tangga dan keaktifannya dalam mengikuti organisasi sosial.

Kurangnya disiplin, pengertian, dan kesadaran masyarakat terhadap kebersihan lingkungan disebabkan oleh faktor sosial, yaitu rendahnya tingkat pendidikan warga masyarakat dan akibat gaya hidup atau pola kebiasaan (prilaku) penduduk, misalnya membuang sampah disembarang tempat, disungai, atau diselokan depan rumah (Taylor \& William dalam Al Muhdhar 2003).

Temuan lain sebagai pendukung penelitian ini adalah hasil penelitian Setiowati, (2011) bahwa pegembangan modul multimedia pengelolaan sampah berwawasan sains, dan masyarakat sebagai baik pada uji coba skala kecil maupun uji coba skala luas dapat meningkatkan sikap peserta didik. Hasil penelitian pada uji coba skala kecil dengan menggunakan analisis Gain score terhadap sikap peserta didik bahwa pada tes sikap terdapat peningkatan yang cukup pada sikap peserta didik setelah dilakukan pembelajaran dengan modul multimedia pengelolaan sampah berwawasan STM (Sains, Teknologi dan Masyarakat).

Hasil penelitian diatas didukung pendapat Setiowati (2010) Pembelajaran tentan pengelolaan sampah, bukan hanya pada aspek pengetahuan dan skill peserta didik saja, melainkan untuk membentuk suatu pembiasaan menuju prilaku yang positif terhadap sampah. Supaya peserta didik mempunyai sikap dan kesadaran yang baik terhadap sampah, untuk itu diperlukan proses penyadaran sehingga bisa menjawab keinginan mereka yaitu mengapa saya harus melakukan ini terhadap sampah, apa manfaatnya jika saya melakukan dan apa dampak mengerikan jika saya mengabaikan. 
Sikap dapat ditumbuh kembangkan melalui proses belajar. Penerapan pembelajaran berbasis konstruktivistik dalam hal ini pembelajaran berbasis proyek pada mata pelajaran Biologi merupakan upaya pembinaan kesadaran terhadap lingkungan sekitar misalnya pengelolaan sampah. Melalui pembelajaran konstruktivistik, siswa dilatih mengkonstruksi sendiri pengetahuannya secara mandiri sehingga dari kegiatan pembelajaran siswa merasa memilki dan mencintai lingkungannya serta dapat membentuk sikap dan prilaku positif terhadap lingkungan, (Gerungan 2000 dalam Darmawan, 2009).

\section{Keterampilan Siswa SMAN Kota Sumbawa Besar dalam Pengelolaan Sampah}

Berdasarkan hasil penelitian nilai rata-rata kelompok secara keseluruhan dalam keterampilan proyek siswa dalam pengelolaan sampah dengan menggunakan konsep 6M. SMAN Kota Sumbawa Besar yaitu sebasar 74.9 tergolong kategori baik. Sedangkan pada kelas kontrol pelaksanaan Project Based Learning tidak diterapkan oleh guru bidang studi sehingga dengan demikian dapat disimpulkan bahwa strategi pembelajaran berbasis proyek berbantuan media $D V D$ $6 M$ antara kelas eksperimen memiliki perbedaan. Hal ini dapat dimakani pada kelas kontrol tidak menerapkan pembelajaran tersebut maka sebagai nilai perbandingan dianggap nol. Berdasarkan uraian diatas dapat disimpulkan bahwa strategi pembelajaran berbasis proyek berbantuan media $D V D 6 M$ efektif sebagai media pendidikan dalam mengembangkan keterampilan kepada siswa dalam pengelolaan sampah.

Temuan dalam penelitain ini didukung oleh hasil penelitian Al Muhdhar (2011) pada Uji coba pruduk skala kecil dalam pengembangan E-Media 
Pendidikan kepada masyarakat dalam pengelolaan sampah rumah tangga. Menunjukan produk software E-Media $V C D 6 M$ efektif sebagai media pendidikan kepada masyarakat dalam pengelolaan sampah rumah tangga. Hasilnya E-Media $V C D$ 6M dapat meningkatkan pemahaman dan keterampilan siswa masyarakat baik melalui jalur pendidikan formal maupun jalur pendidikan non formal.

Hasil penelitian lain sebagai pendukung penelitian ini adalah penelitian $\mathrm{Al}$ Muhdhar (2011) uji coba skla luas terhadap produk E-Media DVD 6M berbasis elektronik telivisi melalui $J-T V$ dengan subyek penelitian yaitu Lumajang. Hasilnya menunjukkan terjadinya peningkatan nilai pemahaman atau pembudayaan $6 \mathrm{M}$ oleh masyarakat dalam pengelolaan sampah rumah tangga. Hasil temuan lain dalam penelitian ini pada uji coba skala kecil dan skala luas yang dilakukan oleh Setiowati, dkk, (2010) bahwa pembelajaran dengan E-Media 6M dapat meningkatkan pemahaman dan keterampilan masyarakat baik pada jalur formal maupun non formal.

Keterampilan menurut Salam (1998 dalam Ruchima, 2011). Bahwa keterampilan ini menuntut siswa untuk mampu menguraikan dan memahami berbagai aspek secara bertahap agar sampai kepada suatu formula baru yaitu kesimpulan. Ketika siswa melakukan observasi, siswa siswa mampu menarik kesimpulan sendiri. Siswa dituntut melakukan proses berpikir secara deduktif untuk mencapai simpulan tersebut. Jadi kesimpulan merupakan sebuah proses berpikir yang memberdayakan pengetahuan sedemikian rupa untuk menghasilkan sebuah pemikiran atau pengetahuan yang baru melalui proses berpikir deduktif. 


\section{E. Pengaruh Strategi Pembelajaran Berbasis Proyek Berbantuan Media DVD 6M Terhadap Kemampuan Berpikir Kritis SMAN Kota Sumbawa}

Berdasarkan hasil analisis kovariansi data nilai kemampuan berpikir kritis siswa SMAN Kota Sumbawa ditemukan adanya perbedaan pengaruh yang signifikan antara siswa yang dibelajarkan strategi pembelajaran berbasis proyek berbantuan media $D V D 6 M$ terhadap kemampuan berpikir kritis siswa di SMAN Kota Sumbawa Besar $(\mathrm{p}=0.004)$. Artinya hipotesis nol ditolak dan hipotesis penelitian diterima bahwa ada perbedaan kemampuan berpikir kritis antara siswa yang difasilitasi strategi pembelajaran berbasis proyek berbantuan media DVD $6 M$ dibanding pembelajaran yang kelas konvensional.

Hasil uji lanjut menunjukkan bahwa nilai kemampuan berpikir kritis siswa yang melaksanakan penerapan $D V D 6 M$ melalui strategi pembelajaran berbasis proyek $(18,8)$ lebih tinggi dibandingkan dengan strategi pembelajaran yang konvensional $(17,39)$. Berdasarkan hasil temuan diatas dapat dijelaskan bahwa hasil penelitian ini menunjukan peserta didik yang banyak terlibat dalam pembelajaran pembelajaran berbasis proyek memiliki rata-rata nilai kemampuan berpikir kritis lebih tinggi dibandingkan dengan peserta didik mengikuti pembelajaran secara konvensional

Temuan dalam penelitian ini didukung oleh pernyataan Sudrajat (2008 dalam Hotima, 2011) menyatakan bahwa proses berpikir adalah berkembangnya ide dan konsep dalam diri seseorang. Proses berpikir tidak dapat berkembang dengan sendirinya, melainkan harus selalu dilatih. Ini pula menjadi alasan pentingnya membelajarkan berpikir kritis pada peserta didik disekolah, karena proses berpikir harus dilatih baik dengan berbagai cara termasuk juga penggunaan perangkat pembelajaran dengan strategi yang digunakan. Hal yang harus di 
pertimbangkan adalah kesiapan peserta didik, kesiapan guru dan juga ketersediaan bahan ajar yang akan digunakan.

. Melalui strategi pembelajaran berbasis proyek berbantuan media $D V D$ $6 M$ siswa memungkinkan dapat mengembangkan ide dan konsep yang baik dalam dirinya dengan berlatih secara terus menerus sehingga tujuan pembelajaran yang diharapkan dapat tercapai. Temuan lain sebagai pendukung dalam penelitian ini adalah penelitian Mahanal (2009) terkait penerapan pembelajaran lingkungan hidup berbasis proyek untuk memberdayakan kemampuan berpikir kritis, penguasaan konsep, dan sikap siswa. Hasil penelitian menunjukan pembelajaran lingkungan hidup berbasis proyek dapat memberdayakan kemampuan berpikir kritis siswa di SMAN 9 Malang.

Kemampuan berpikir kritis merupakan salah satu modal yang harus dimiliki siswa dalam sebagai bekal dalam menghadapi perkembangan ilmu pengetahuan dan teknologi pada masa sekarang ini salah satu contoh adalah teknologi E-Media 6M tentang pengelolaan sampah, yang diterapkan dalam penelitian ini melalui strategi pembelajaran berbasis proyek. Kemampuan untuk dapat berhasil dalam kehidupan antara lain ditentukan oleh kemampuan berpikirnya, terutama dalam pemecahan masalah kehidupan yang dihadapinya (Ibrahim 2007 dalam Dwijananti 2010).

Besarnya peranan pendidik dalam meningkatkan kemampuan berpikir kritis seyogyanya diimbangi oleh kemampuan pendidik dalam mengusai berbagai strategi pembelajaran inovatif. Kemampuan pendidik menggunakan berbagai macam strategi pembelajaran baru, dapat mengurangi bahkan menghilangkan kejenuhan peserta didik dalam menerima pembelajaran. Peserta didik yang 
terbiasa mengasa kemampuan berpikir kritisnya akan berimplikasi menjadi watak dan prilakunya dalam kehidupan. Pribadi yang mengiplementasikan keperibadian berpikir kritis akan selalu bertindak rasional dalam menyikapi segalah sesuatu. Pribadi-pribadi yang memiliki keperibadian berpikir kritis akan menjadi manusia yang unggul dan siap menghadapi kehidupan abad yang akan datang Hadi (2007 dalam Hotima, 2011).

\section{F. Pengaruh Strategi Pembelajaran Berbasis Proyek Berbantuan Media DVD 6M Terhadap Pengetahuan Siswa SMAN Kota Sumbawa Besar}

Hasil analisis kovariansi menunjukan adanya pengaruh yang signifikan strategi pembelajaran berbasis proyek berbantuan media DVD 6M terhadap pengetahuan siswa SMAN Kota Sumbawa Besar $(\mathrm{p}=0.000)$. Artinya hipotesis nol ditolak dan hipotesis penelitian diterima bahwa ada perbedaan pengetahuan antara siswa yang difasilitasi strategi pembelajaran berbasis proyek berbantuan media $D V D 6 M$ dibanding pembelajaran yang kelas konvensional. Hasil uji lanjut diketahui bahwa perbedaan rata-rata terkoreksi dari penerapan DVD $6 M$ melalui strtegi pembelajaran berbasis proyek $(20,64)$ lebih tinggi dibandingkan dengan strategi pembelajaran yang konvensional $(18,76)$.

Berdasarkan hasil temuan diatas dapat dijelaskan bahwa hasil penelitian ini menunjukan peserta didik yang banyak terlibat dalam pembelajaran pembelajaran berbasis proyek berbantuan media $D V D 6 M$ memiliki rata-rata nilai pengetahuan lebih tinggi dibandingkan dengan peserta didik mengikuti pembelajaran secara konvensional

Temuan dalam penelitian ini didukung oleh hasil penelitian Porworeni (2009) bahwa pembelajaran berbasis proyek dapat meningkatkan hasil belajar 
siswa di SMP Nasional KPS Balikpapan. Temuan lain didukung oleh hasil penelitian Setiowati (2011) menunjukan pembelajaran dengan menggunakan modul multimedia dalam pengelolaan sampah sangat efektif meningkatkan pengetahuan peserta didik dengan keterlaksanaan tergolong sangat baik.

Berdasarkan uraian diatas bahwa alasan mendasar diterapkannya strategi pembelajaran berbasis proyek berbantuan media $D V D 6 M$ yaitu pembelajaran selama ini cendrung bersifat teacher centered sehingga siswa menjadi sangat tergantung pada guru sehingga siswa tidak terbiasa melihat melihat alternatif lain yang mungkin dipakai menyelesaikan suatu permasalahan, metode pembelajaran yang selama ini diterapkan guru seperti ceramah, latihan soal, penugasan, dan investigasi tidak memberikan hasil yang maksimal. Untuk mengatasi kondisi demikian diperlukan strategi yang efektif. Strategi pembelajaran berbasis proyek melibatkan berbagai tahapan yang mampu meningkatkan pengetahuan siswa, melalui proyek siswa mampu melibatkan seluruh mental dan fisik, syaraf, indera termasuk kecakapan sosial dengan melakukan banyak hal sekaligus (Purworeni, 2009)

Hasil penelitian lain sebagai pendukung hasil penelitian ini yaitu penelitian Darmawan (2010) tentang pengaruh pembelajaran berbasis proyek terhadap hasil belajar menunjukan adanya perbedaan yang signifikan penguasaan konsep antara siswa yang difasilitasi dengan pembelajaran proyek dibandingkan dengan kelas konvensional. Penguasan kosep dalam belajar dapat dimaknai sebagai kemampuan siswa untuk mengungkapkan makna atau konsep (materi yang dipelajari). Pengusaan konsep tidak hanya sekedar mengingat tetapi individu hendaknya mampu menerapkan konsep-konsep tersebut kedalam suatu rangkaian 
permasalahan. Siswa yang sudah mengusai konsep suatu obyek akan lebih mudah menerapkan dalam pemecahan masalah sebab suatu konsep dapat dibentuk melalui pengalaman langsung dengan obyek atau kejadian dalam kehidupan. (Wang dkk, dalam Darmawan 2009).

Porworeni (2009) bahwa strategi pembelajaran berbasis proyek menganut paham konstruktivistik dan kontekstual, sehingga informasi yang didapat siswa tidak lagi bersifat abstrak tetapi nyata dan secara umum siswa mendapat pengalaman langsung, menumbuhkan kemandirian, meningkatkan kerjasama diantara siswa meningkatkan motivasi belajar serta mengembangkan kecakapan hidup. Peran guru dalam Strategi pembelajaran berbasis proyek hanya bertindak sebagai fasilitator, hal ini selaras dengan pernyataan Gaer (1998) bahwa pembelajaran berbasis proyek memotivasi siswa untuk belajar dengan membiarkan mereka untuk memilih topik-topik yang bersifat menarik, bermakna, dan relevan dalam kehidupan mereka. Melalui proyek yang mereka kerjakan, siswa akan memperoleh pengetahuan yang lebih dalam, belajar mandiri serta dapat meningkatkan kemampuan dalam mengasah keterampilan memacahkan masalah Sasti (2008 dalam Darmawan, 2009).

Selain itu, bukti-bukti lain yang mendukung penelitian ini adalah hasil penelitian Al Muhdhar (2003) tentang keterkaitan faktor sosial, ekonomi, pengetahuan, dan sikap dengan manifestasi prilaku ibu-ibu rumah tangga dalam pengelolaan sampah di Kota Surabaya. Hasil penelitian dengan metode stepwise menunjukan bahwa pengetahuan ibu-ibu rumah tangga di tentukan oleh faktor kunci tingkat pendidikan ibu-ibu rumah tangga dan jumlah media imformasi yang dimilikinya. Kaitanya dengan penelitian iini yaitu melalui media informasi berupa 
DVD 6M dengan strategi pembelajaran berbasis proyek siswa dapat mengaplikasikan pengetahuannya sesuai dengan tugas proyek yang diberikan oleh guru. Selain tingkat pendidikan yang berpengaruh terhadap pengetahuan siswa yaitu jumlah informasi yang dimiliki. Semakin banyak media informasi yang dimiliki oleh peserta didik semakin tinggi pula pengetahuan dalam pembelajaran.

Pembelajaran berbasis proyek merupakan strategi pembelajaran yang memperhatikan pemahaman. Siswa melakukan eksplorasi, penilaian, interpretasi dan mensentesis informasi melalui cara yang bermakna The George Lucus Educational Foundation, (2005 dalam Nurohman, 2008). Pembelajaran berbasis proyek dapat mengembangkan kemampuan berpikir produktif, melalui belajar kolaboratif siswa saling belajar yang nantinya akan meningkatkan pemahaman konseptual maupun kecakapan teknikal, holistik dan interdisifliner, realistik, berorentasi pada belajar aktif memecahkan masalah riil, yang memberi konstribusi pada pengembangan kecakapan pemecahan masalah dan memberikan reinforcement intrinsik (umpan balik internal) yang dapat menajamkan kecakapan berpikir produktif.

Hasil penelitian lain sebagai pendukung hasil ini yaitu penelitian Rais, M (2010) meneliti tentang penerapan strategi pembelajaran berbasis proyek sebagai upaya meningkatkan prestasi akademik mahasiswa. Hasil penelitian menujukan bahwa rata-rata prestasi akademik mahasiswa yang dipasilitasi pembelajaran berbasis proyek menunjukan peningkatan prestasi akademik mahasiswa di Universitas Negeri Makasar. Implikasi pendidikan, dalam upaya meningkatkan hasil belajar guru hendaknya memilih strategi pembelajaran yang memungkinkan siswa aktif mengkonstruk pengetahuan sendiri melalui pembelajaran berbasis 
proyek Sesuai dengan pendapat Callahan (1992 dalam Indriwati, 2007) bahwa strategi pembelajaran merupakan faktor kunci dalam meningkatkan hasil belajar.

Penyataan diatas didukung oleh Slavin (1995) menjelaskan bahwa dengan adanya komunikasi antara peserta didik yang satu dengan yang lain dalam pasangan akan membangkitkan hubungan sosial antar peserta didik, melatih komunikasi, dan saling berdiskusi tentang materi pelajaran. Intraksi sosial dengan tema sebaya melalui kerja kelompok memacu terbentuknya ide dan memperkaya perkembangan mental anak (Ibrahim dan Nur dalam Hotima, 2011). Pembelajaran dengan partisifasi aktif peserta didik ini memiliki beberapa persepektif yang dapat dikembangkan, yaitu perspekstif motivasi, sosial, kognitif, elabrasi kognitif dan psikologis. Slavin (1995 dalam Arends, 2004).

\section{G.Pengaruh Strategi Pembelajaran Berbasis Proyek Berbantuan Media DVD 6M Terhadap Sikap Siswa di SMAN Kota Sumbawa Besar}

Hasil perhitungan anakova menunjukan adanya pengaruh yang signifikan strategi pembelajaran berbasis proyek berbantuan media $D V D 6 M$ terhadap sikap siswa di SMAN Kota Sumbawa Besar $(\mathrm{p}=0.000)$. Artinya hipotesis nol ditolak dan penelitian diterima bahwa ada perbedaan pengetahuan yang signifikan antara siswa yang diberi pembelajaran berbasis proyek berbantuan media DVD $6 M$ dibanding siswa yang dibelajarkan pembelajaran melalui strategi konvensional. Hasil uji lanjut untuk nilai sikap menunjukkan ada perbedaan rata-rata terkoreksi dari penerapan DVD $6 M$ melalui strategi pembelajaran berbasis proyek $(20,43)$, lebih tinggi dibandingkan dengan strategi pembelajaran yang konvensional $(15,76)$. 
Berdasarkan hasil temuan diatas dapat dijelaskan bahwa hasil penelitian ini menunjukan peserta didik yang banyak terlibat dalam pembelajaran berbasis proyek berbantuan DVD $6 M$ memiliki rata-rata nilai sikap lebih tinggi dibandingkan dengan peserta didik mengikuti pembelajaran secara konvensional

Temuan yang mendukung penelitain ini yaitu penelitian Darmawan (2009) pengaruh penerapan pembelajaran berbasis proyek terhadap sikap siswa pada lingkungan hidup menunjukan ada perbedaan yang signifikan sikap terhadap lingkungan hidup antara siswa yang difasilitasi pembelajaran berbasis proyek dibandingkan dengan pembelajaran yang diberikan secara konvensional.

Sikap muncul dari berbagai bentuk penilaian, sikap dikembangkan dalam tiga model, yaitu: afeksi, kecendrungan perilaku dan kognisi. Respon afektif adalah respon fisiologis yang mengekspresikan kesukaan individu terhadap sesuatu. Kecendrungan perilaku adalah indikasi verbal dari maksud seorang individu. Respon kognitif adalah pengevaluasian secara kognitif terhadap suatu obyek sikap. kebanyakan sikap individu adalah hasik belajar sosial dari lingkunganya. Jika dikaitkan dengan penelitian ini bahwa dalam pembelajaran berbasis proyek melalui pelaksanaan proyek peserta didik dilatih untuk dapat mengembangkan sikapnya baik afeksi, kognisi maupun konasi dengan tujuan agar siswa memiliki respon afektif yang baik terhadap lingkungan.

Uraian diatas didukung oleh Tesser (2003 dalam Darmawan, 2009) bahwa sikap dapat mengalami perubahan akibat dari pengalaman, suatu metode pembelajaran yang mampu mengakibatkan perubahan sikap dalam hal ini strategi pembelajaran berbasis proyek, strategi pembelajaran ini mampu meningkatkan sikap siswa terhadap lingkungan hidup karena awalnya menanamkan konsep yang 
benar dan maksimal untuk perkembangan fisik siswa. Hal senanda juga dikemukakan oleh Wahyudi (1998 dalam Mahanal, 2009) bahwa jalur pendidikan merupakan usaha untuk mencapai terwujudnya masyarakat yang memiliki sikap dan prilaku berwawasan lingkungan. Sekolah sebagai lingkungan belajar mempunyai perempuan mempunyai peran strategis terhadap pemberdayaan sikap. Melalui proses belajar terjadi proses komunikasi dan transfer pengetahuan dan nilai. Dengan demikian sikap terletak pada proses kognisi dalam belajar siswa.

Sikap positif terhadap lingkungan melalui strategi pembelajaran Proyek juga terbentuk akibat nilai sosial yang ada dalam strategi pembelajaran berbasis proyek. Dalam pembelajaran berbasis proyek terdapat nilai kooperatif sehingga siswa terbiasa berinteraksi dengan rekan sekelompok untuk menyusun berbagai rancangan aktifitas yang berkaitan dengan materi yang diajarkan. Kegiatan diskusi membuka peluang terjadinya interaksi di mana mendiskusikan apa yang mereka ketahui dan siswa diarahkan untuk mempertimbangkan lebih dari satu sudut pandang (siswa akan saling bertukar pikiran).

Corebima (2008 dalam Darmawan, 2009) menjelaskan bahwa untuk mengembangkan kecakapan berpikir perlu dikembangkan strategi kolaboratif yang dapat membantu siswa belajar berkomunikasi satu sama lain dan bekerja dalam kelompok. Selain itu dalam pembelajaran berbasis proyek diperlukan interaksi antar siswa terutama dalam membelajarkan materi yang di inginkan.

Hasil penelitian lain yang mendukung penelitian ini yaitu (Wibowo dalam Darmawan, 2009) bahwa startegi pembelajaran berbasis proyek dapat mempengaruhi sikap siswa terhadap ekosistem sungai. Selain itu Mahanal dkk (2009) bahwa pembelajaran lingkungan hidup berbasis proyek memiliki pengaruh 
terhadap perkembangan sikap siswa. Berdasarkan urain diatas maka dapat disimpulkan bahwa penerapan strategi pembelajaran berbasis proyek berbantuan DVD 6M berpengaruh terhadap sikap siswa di SMAN Kota Sumbawa Besar. 


\section{BAB VI}

\section{PENUTUP}

\section{A. Kesimpulan}

Berdasarkan hasil pembahasan dan analisis data dangan statistik dapat disimpulkan sebagai berikut.

1. Rerata nilai kemampuan berpikir kritis siswa dalam pengelolaan lingkungan SMAN Kota Sumbawa yang dibelajarkan pembelajaran berbasis proyek berbantuan media $D V D 6 M$ lebih tnggi dibanding kelas konvensional.

2. Rerata nilai pengetahuan siswa dalam pengelolaan lingkungan SMAN Kota Sumbawa yang dibelajarkan pembelajaran berbasis proyek berbantuan media DVD $6 M$ lebih tnggi dibanding kelas konvensional.

3. Rerata nilai sikap siswa dalam pengelolaan lingkungan SMAN Kota Sumbawa yang dibelajarkan pembelajaran berbasis proyek berbantuan media $D V D 6 M$ lebih tnggi dibanding kelas konvensional.

4. Rerata nilai keterampilan kelompok siswa SMAN Kota Sumbawa dalam pengeloaan sampah pada kelas eksperimen tergolong kategori baik.

5. Ada perbedaan kemampuan berpikir kritis dalam pengelolaan ligkungan antara siswa yang diberi strategi pembelajaran berbasis proyek berbantuan media DVD 6M dengan yang diberi pembelajaran konvensional. 
6. Ada perbedaan pengetahuan dalam pengelolaan lingkungan antara siswa yang diberi strategi pembelajaran berbasis proyek berbantuan media DVD 6M dengan yang diberi pembelajaran konvensional.

7. Ada perbedaan sikap dalam pengelolaan lingkungan antara siswa yang diberi strategi pembelajaran berbasis proyek berbantuan media $D V D 6 \mathrm{M}$ dengan yang diberi pembelajaran konvensional.

\section{B. Saran}

Beradasarkan kesimpulan yang diperoleh dalam penelitian ini, maka dapat diajukan saran agar dapat menjadi pertimbangan bagi semua pihak yang berkepentingan adalah sebagai berikut.

1. Hasil penelitian menunjukan bahwa media $D V D 6 M$ yang digunakan dalam pembelajaran berbasis proyek dapat digunakan untuk meningkatkan kemampuan berpikir kritis sehingga dapat direkomendasikan untuk diterapkan oleh guru dalam mata pelajaran biologi maupun mata pelajaran lain yang relevan dengan kompetensi dasar yang diajarkan.

2. Bahwa media $D V D 6 M$ yang digunakan dalam strategi pembelajaran berabasis proyek efektif dalam meningkatkan pengetahuan, dan sikap siswa dalam pengelolaan lingkungan maka guru hendaknya dapat memilih startegi pembelajaran yang relevan dalam upaya mengembangkan pengetahuan, sikap dan keterampilan siswa dalam memahami lingkungan.

3. Hasil penelitian menunjukan bahwa media $D V D 6 M$ yang digunakan melalui startegi pembelajaran berbasis proyek terbukti efektif dalam memberdayakan keterampilan siswa dalam pengelolaan sampah. 
4. Bagi peneliti lainya yang berminat menggunakan strategi pembelajaran berbasis proyek berbantuan media $D V D 6 M$ diperlukan pengembangan peneliti lainnya agar penerapan perangkat pembelajaran dan produk yang diterapkan ini dapat di tindaklanjuti pada mata pelajaran lain. 


\section{DAFTAR RUJUKAN}

Ahmad. R. 2011. Penerapan Autentik Asesmen Terhadap Keterampilan Berpikir Kritis dan Hasil Belajar di SMAN 2 Malang. Tesis tidak diterbitkan Malang: Program Pascasarjana Universitas Negeri Malang.

Al Muhdhar, M.H.I. 1998. Keterkaitan Antara Faktor Sosial, Faktor Ekonomi, Faktor Budaya, Pengetahuan, dan Sikap dengan Manifestasi Perilaku Ibuibu Rumah Tangga dalam Pengelolaan Sampah Rumah Tangga di Kota Madia Surabaya. Disertasi tidak diterbitkan. Malang: IKIP Malang.

Al Muhdhar, M.H.I. 1999. Pengetahuan Ibu-ibu Rumah Tangga Dalam Pengelolaan Sampah Rumah Tangga Di Kotamadya Surabaya. Jurnal Ilmu Pendidikan, 33(1): 121-130.

Al Muhdhar, M.H.I. 2003. Keterkaitan faktor sosial, ekonomi, pengetahuan, dan sikap dengan manifestasi perilaku ibu-ibu rumah tangga dalam pengelolaan sampah rumah tangga di kota surabaya. Jurnal Ilmu Pendidikan, 10 (2): 174-175.

Al Muhdhar, M.H.I, \& Sesilowati, 2010. Penerapan E-Media Pendidikan kepada Masyarakat dalam Pengelolaan Sampah Rumah Tangga melalui Jalur Pendidikan Formal dan Non Formal untuk Meningkatkan Pemahaman dan Keterampilan Masyarakat dalam Pengelolaan Sampah Rumah Tangga di Kota Malang. Laporan Penelitian Hiba Bersaing: Universitas Negeri Malang.

Al Muhdhar, M.H.I. \& Susilowati, 2011. Penerapan E-Media Pendidikan kepada Masyarakat pada Media Telivisi untuk Meningkatkan Pemahaman dan Pembudayaan Masyarakat dalam Pengelolaan Sampah Rumah Tangga di Jawa Timur. Laporan penelitian Hibah Bersaing: Universitas Negeri Malang.

Arikunto, S.2006. Prosedur Penelitian suatu Pendekatan Praktik. Jakarta: Rineka cipta

BSNP. 2006. Standar isi Jakarta: Badan Standar Nasional Pendidikan.

Darmawan E. 2009. Pengaruh Pembelajaran Project Based Learning Pada Materi Ekosistem Terhadap Sikap dan Hasil Belajar Siswa SMAN 2 Ma lang. Skripsi tidak diterbitkan. Malang: Universitas Negeri Malang.

Dimyanti, 1994. Belajar dan Pembelajaran. Jakarta: Proyek Pengembangan dan Peningkatan Mutu Tenaga Kependidikan.

Dwijananti \& Yulianti. 2010. Pengembangan Kemampuan Berpikir Kritis Mahasiswa Melalui Pembelajaran Problem Based Instruction pada mata 
kuliah fisika lingkungan. Jurnal Pendidikan Fisika Indonesia. 6 (10): 08114. (http: //journal Unnes, ac, id.) diakses 17 Mei 2012.

Departemen Pekerjaan Umum. 1990b. Standar Tata Cara Pengelolaan Teknik Sampah Perkotaan. Bandung: Yayasan LPMB.

Departemen Pekerjaan Umum 1993. 1993a. Perencanaan Tempat Pembuangan Akhir Sampah Kotamadia Malang. Final Report Februari 1993. Jakarta: Departemen Pekerjaan Umum Dirjen Cipta Karya Direktorat Penyehatan Lingkungan Pemukiman.

Fisher A. 2009. Berpikir Kritis Sebuah Pengantar. Erlangga: PT Glora Aksara Pratama

Gaer, S. 1998. What is Project Based Learning?

http://members.aol.com/CulebraMom/pblprt.html.diakses 6 Mei 2012.

Gerungan. W. A. 2000. Psikologi Sosial. Bandung: Refika Aditama

Hotima, H. 2011. Pengaruh Perangkat Pembelajaran Genetika Melalui Pendekatan Konstruktivistik model Learning Cycle Terhadap Kemampuan Berpikir Kritis Dan Pemahaman Konsep Siswa SMA Negeri 1 Jember. Disertasi tidak diterbitkan. Malang: Program Pascasarjana Universitas Negeri Malang.

Huda, A. 2009. Peningkatan Mutu Pembelajaran dengan Pembelajaran Berbasis Proyek (Online), http://hudaita.blogspot.com/2009_04_01_archive.html, diakses 06 Mei 2012.

Ibrohim, 2009. Pengaruh Model Implementasi Lesson Study Dalam Kegiatan MGMP Terhadap Peningkatan Komptensi Guru dan Hasil Belajar Biologi Siswa.Disertasi tidak diterbitkan Malang: Program Pascsarjana Universitas Negeri Malang.

Mahanal, S. 2008. Pengembangan Perangkat Pembelajaran Deteksi Kualitas Sungai Dengan Indikator Biologi Berbasis Konstruktivistik untuk Memberdayakan Berpikir Kritis dan Sikap Siswa SMA terhadap Ekosistem Sungai di Malang. Disertasi tidak diterbitkan. Malang: Program Pascasarjana Universitas Negeri Malang.

Manhanal, S 2009. Penerapan Pembelajaran Lingkungan Hidup Berbasis Proyek untuk Memberdayakan Kemampuan Berpikir Kritis.Penguasaan Konsep,dan Sikap Siswa.Studi SMA Negeri 9 Malang.Makalah disajikan dalam seminar Nasional Pendidikan Lingkungan Hidup dan Interkonfrensi BKPSL. Universitas Negeri Malang.

Nasution M, 2008 Pengelolaan Lingkungan Hidup (online) http://www.google.co.id. Diakses 24 Juni 2012. 
Nurhadi, 2003. Pembelajaran Kontekstual dan Penerapan dalam KBK. Malang: Universitas Negeri Malang

Nurohman. S. 2008. Pendekatan PBL Sebagai Upaya Internalisasi Scientific Method bagi Mahasiswa Calon Guru (online).http://staff.uny.ac.id/sites/default/files/132309687/project-based learning.pdf, Diakses 06 Mei 2012.

Rais, M. 2010. Model Project Based Learning Sebagai Upaya Meningkatkan Prestasi Akademik Mahasiswa. Jurnal Pendidikan dan pengajaran, (Online), 3 (10): 246-252. (http://www raismisi gmail,com), diakses 17 Maei 2012.

Sadono, G. \& Antonius. 1996. Limbah Domestik. Makalah disajikan dalam Kegia tan Penyuluhan Lingkungan Hidup Pengurus PKK Kota Madya Malang tanggal 18 September 1996. Malang : Dinas Kesehatan Daerah Kotamadya Daerah Tingkat II Malang.

Setiowati, E. 2010. Pengembangan Modul Multimedia Pengelolaan Sampah Berwawasan Sains, Teknologi, dan Masyarakat Sebagai Upaya Untuk Meningkatkan Pengetahuan Sikap, dan Prilaku Peserta didik. Disertasi tidak diterbitkan. Malang: Program Pascasarjana Universitas Negeri Malang.

Sudjana, N.1990. Penilaian Hasil Proses Belajar Mengajar. Bandung: PT. Remaja Rosdakarya.

Sudjana, A. 2007. Kamus Lengkap Biologi. Jakarta: Mega Aksara Jakarta

Thomas, J.W. 2000 A Review of Research On Project-Based Learning http://www.bobpearlman.org/BestPractices/PBL_Research.pdf , diakses 06 Mei 2012

Tuckman W.1999 Conducting Educational Research http://www.odu.edu/ jritz/attachments/coedre.pdf , diakses 06 Mei 2012

Johnson, D. Johnson. \& Stanne, 2000. Cooverative Laerning Methods : A Meta Analisis. (online), (http://www.clcrc .com./pages/cl-methods html.diakses Mei 2012

Purworini, S. E. 2006. Pembelajaran Berbasis Proyek Sebagai Upaya Meningkatkan Habit Of Mind "Studi Kasus di SMP Nasional KPS Balikpapan" Jurnal Pendidikan Inovatif, (Online), 1 (2): 17-19, (http://blog.tp.ac.id), diakses 06 Mei 2012.

Vygotsky, L, S. 1978.A review od Reaserch on Proyek besed Laerning. (Online), (http : //www.autodeks.com/fundacition, diakses Agustus 2012 